\title{
Checklist of fossil liverworts suitable for calibrating phylogenetic reconstructions
}

\author{
KATHRIN FELDBERG ${ }^{1, *}$, S. ROBBERT GRADSTEIN ${ }^{2}$, CARSTEN GRÖHN ${ }^{3}$, JOCHEN HEINRICHS ${ }^{4, \dagger}$, \\ MATT VON KONRAT ${ }^{5}$, YURIY S. MAMONTOV ${ }^{6}$, MATT A. M. RENNER ${ }^{7}$, MADITA ROTH ${ }^{1}$, ALFONS \\ SCHÄFER-VERWIMP ${ }^{8}$, PHIANGPHAK SUKKHARAK ${ }^{9} \&$ ALEXANDER R. SCHMIDT $^{1}$ \\ ${ }^{1}$ Department of Geobiology, University of Göttingen, Goldschmidtstraße 3, 37077 Göttingen, Germany; \\ "="kathrin.feldberg@uni-goettingen.de; @ https://orcid.org/0000-0002-9431-7193 \\ ఏalexander.schmidt@geo.uni-goettingen.de; 이ttps://orcid.org/0000-0001-5426-4667 \\ ${ }^{2}$ Department of Systematics, Biodiversity and Evolution of Plants, Albrecht von Haller Institute for Plant Sciences, University of \\ Göttingen, 37073 Göttingen, Germany; Muséum National d'Histoire Naturelle, Institute de Systematique, Évolution, Biodiversité (UMR \\ 7205), 75005 Paris, France; \\ "s sgradst@gwdg.de; @ https://orcid.org/0000-0002-3849-6457 \\ ${ }^{3}$ Amber Study Group, clo Geological-Palaeontological Institute and Museum (CeNak) of the University of Hamburg, Bundesstraße 55, \\ 20146 Hamburg, Germany; \\ "jcgroehn@t-online.de \\ ${ }^{4}$ Department of Biology I, Systematic Botany and Mycology, Geobio-Center, University of Munich (LMU), Menzinger Straße 67, 80638 \\ Munich, Germany \\ ${ }^{5}$ Gantz Family Collections Center, Science \& Education, Field Museum, 1400 South Lake Shore Drive, Chicago, IL 60605-2496, USA; \\ झ"mvonkonrat@fieldmuseum.org; (1) https://orcid.org/0000-0001-9579-5325 \\ ${ }^{6}$ Tsitsin Main Botanical Garden, Russian Academy of Sciences, Moscow, 127276 Russia; \\ "=yur-mamontov@yandex.ru; ○ https://orcid.org/0000-0003-3851-0738 \\ ${ }^{7}$ Royal Botanic Gardens and Domain Trust, Mrs Macquaries Road, Sydney, NSW 2000, Australia; \\ झ”matt.renner@rbgsyd.nsw.gov.au; @ i https://orcid.org/0000-0003-2286-7257 \\ ${ }^{8}$ Mittlere Letten 11, 88634 Herdwangen-Schönach, Germany;

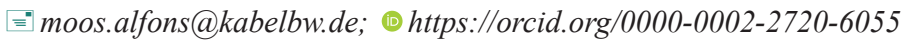 \\ ${ }^{9}$ Department of Biology, Faculty of Science, Burapha University, 169, Long-Hard Bangsaen Road, Mueang, 20131, Chonburi, Thailand; \\ "="phiangphak@buu.ac.th; @ https://orcid.org/0000-0001-5330-1411 \\ *corresponding author \\ $\dagger$. Heinrichs is deceased
}

\begin{abstract}
The number of available liverwort fossils substantially increased within the past decade, which is mainly due to new findings from Cretaceous and Cenozoic amber deposits. Many of them, however, are fragmentary and not predestined for consideration in evolutionary analyses. Here, we list those liverwort fossils that we suggest as suitable for calibrating phylogenetic reconstructions, along with brief descriptions, justification of their use, and age information. Our recommendations are based on thorough microscopic investigation of available fossils from worldwide amber collections including recent findings. We recommend that the following 42 fossil taxa can be used as confident minimum age constraints in phylogenetic reconstructions: Acrolejeunea ucrainica (35 Ma), Anastrophyllum rovnoi (35 Ma), Bazzania polyodus (34 Ma), Blepharolejeunea obovata (15 Ma), the genus Bryopteris with B. bispinosa and B. succinea (15 Ma), Calypogeia stenzeliana (34 Ma), Cephaloziella nadezhdae (35 Ma), the genus Ceratolejeunea with C. antiqua, C. palaeomexicana, and C. sublaetefusca (15 Ma), Cheilolejeunea latiloba (34 Ma), Cheirorhiza brittae (158 Ma), Cololejeunea sp. (15 Ma), Cyclolejeunea archaica (15 Ma), Dibrachiella grollei (15 Ma), Diettertia montanensis (112 Ma), Drepanolejeunea eogena (15 Ma), the genus Frullania with F. baerlocheri, F. cretacea, and F. partita (99 Ma), Frullania subgen. Frullania with F. casparyi $(34 \mathrm{Ma}$ ) and F. riclefgrollei $(35 \mathrm{Ma}), F$. subgen. Trachycolea with F. rovnoi $(35 \mathrm{Ma})$ and $F$. schumannii $(34$ Ma), Gackstroemia cretacea (99 Ma), Geocalyx heinrichsii (34 Ma), the genus Lejeunea with L. hamatiloba, L. miocenica, L. resinata, and L. urbanioides (15 Ma), Lopholejeunea subnigricans (15 Ma), Marchantites cyathodoides (228 Ma), Marchesinia brachiata (15 Ma), Metzgeriothallus sharonae (383 Ma), Microlejeunea nyiahae (52 Ma), Neurolejeunea macrostipula (15 Ma), Nipponolejeunea europaea (34 Ma), Notoscyphus balticus (34 Ma), Odontoschisma (sect. Iwatsukia) dimorpha (34 Ma), Plagiochila groehnii (34 Ma), Porella subgrandiloba (34 Ma), Protolophozia kutscheri (34 Ma), Radula (subgen. Odontoradula) cretacea (99 Ma), R. (subgen. Amentuloradula) heinrichsii (99 Ma), Scapania hoffeinsiana (34 Ma), Solenostoma berendtii (34 Ma), Spruceanthus polonicus (34 Ma), Stictolejeunea squamata (15 Ma), Tetralophozia groehnii (34 Ma), Thysananthus auriculatus (15 Ma), Thysananthus contortus (34 Ma). Furthermore, we transfer Lophozia kutscheri to Protolophozia, Archilejeunea grollei to Dibrachiella, Frullania ucrainica to Acrolejeunea, and Mastigolejeunea extincta to Spruceanthus, based on new fossil evidence and morphological revisions.
\end{abstract}


Keywords: Amber, Cenozoic, Cretaceous, divergence time estimates, fossil bryophytes, leafy liverworts, molecular paleontology

\section{Introduction}

Research concerning the evolution and diversification of Marchantiophyta has rapidly progressed in recent years, which coincides with the discovery of new fossils, especially from Cretaceous and Cenozoic amber deposits. The fossil record was reviewed by Heinrichs et al. (2018a) for liverworts in amber and by Tomescu et al. (2018) for bryophytes from the rock record. Since then, the steady discovery of new fossils led to the description of new taxa and allowed better reconstructions of previously known extinct species which resulted in several taxonomic changes and emended descriptions (Feldberg et al. 2018, 2021, Heinrichs et al. 2018b, Katagiri 2018, Katagiri \& Shinden 2020, Mamontov et al. 2018a, 2019, 2020a, Li et al. 2020, 2021, Yu et al. 2020).

An important tool for the study of liverwort evolution are divergence time estimates based on molecular phylogenies (e.g., Heinrichs et al. 2007, 2015b, 2016a, Wilson et al. 2007, Cooper et al. 2012, Feldberg et al. 2013, 2014, 2017, Laenen et al. 2014, Sun et al. 2014, Villarreal \& Renner 2014, Villarreal et al. 2016, Bechteler et al. 2017a, b, Carter et al. 2017, Patiño et al. 2017, Silva et al. 2017, Lee et al. 2020). Especially Bayesian dating methods offer diverse possibilities to define priors and to incorporate information from the fossil record, e.g., BEAST 2 (Bouckaert et al. 2014, Drummond \& Bouckaert 2015) and MCMCTree (Yang 2007). However, the results of these estimates often vary due to conflicting interpretation of the fossil evidence and the taxonomy of extant groups as well as the use of different DNA marker sets, algorithms, tree priors, and different assumptions on the maximum age of lineages. A thorough evaluation and cross-evaluation of different calibration strategies and prior settings is therefore crucial for this approach (e.g., Parham et al. 2012, Warnock et al. 2015, 2017, Barba-Montoya et al. 2017, Bromham et al. 2018, Guindon 2018, Marshall 2019, Beavan et al. 2020, Carruthers \& Scotland 2020, Didier \& Laurin 2020, O’Reilly \& Donoghue 2020).

Recent analyses indicate that many liverwort lineages probably predate the Permian-Triassic boundary while most extant genera originated in the Cretaceous or Cenozoic (e.g., Heinrichs et al. 2018a). The required age constraints on the molecular phylogenetic trees were obtained by using fossil calibrations of ancestral nodes associated with extant lineages (Heinrichs et al. 2007, 2016a, Wilson et al. 2007, Cooper et al. 2012, Feldberg et al. 2013, 2014, Laenen et al. 2014, Sun et al. 2014, Villarreal et al. 2016), by using standard substitution rates (Villarreal \& Renner 2014, Heinrichs et al. 2015b, Bechteler et al. 2017a, Carter et al. 2017, Feldberg et al. 2017, Patiño et al. 2017), or by a combination of both methods (Bechteler et al. 2017b, Silva et al. 2017, Lee et al. 2020).

The classification of fossil material is often challenging, and divergence time estimates which solely rely on fossil constraints might be impeded by incorrect systematic assignment which misleads taxonomic interpretations (e.g., Feldberg et al. 2013, 2017, Bechteler et al. 2017b, Heinrichs et al. 2018a). This is sometimes due to incomplete preservation of fossils but may also result from a high level of morphological homoplasy and cryptic speciation in extant lineages (e.g., Shaw 2001, Renner 2015, 2020, Shaw et al. 2015, Renner et al. 2017a). However, DNA sequence variation of extant species can be employed to evaluate the morphology-based classification of fossils because, for example, the age of fossils may pre-date divergence times estimated among closely related genera (Heinrichs et al. 2015b, 2018a, Villarreal et al. 2016, Bechteler et al. 2017b, Feldberg et al. 2017, Patiño et al. 2017). On the other hand, divergence times that rely solely on DNA sequence variation can be problematic in cases of strongly deviating molecular clocks, as seen in the "slowly" evolving complex thalloid liverworts (Villarreal et al. 2016). Only a compilation of analyses with different approaches allows a thorough cross-validation of hypotheses concerning the evolution of lineages through time, classification of fossils, and the suitability of the fossils as age constraints. Consequently, fossils should not exclusively be used to calibrate nodes in molecular phylogenies, but independently generated phylogenetic chronograms can be used to evaluate taxonomical assessments of fossils and to balance between different taxonomic solutions (Lóriga et al. 2014, Schneider et al. 2015, 2016, Sundue \& Poinar 2016, Bechteler et al. 2017b, Kubilius et al. 2017).

Heath et al. (2014) proposed a fossilized birth-death approach which is designed to overcome the problem of assigning fossils to certain nodes in divergence time analyses by allowing data-based fossil assignment and the expression of uncertainty in fossil placement. Though this approach requires a dense fossil record and numerous morphological character states of both fossils and extant taxa to be coded (e.g., Arcila et al. 2015, Warnock et al. 2015, Didier \& Laurin 2020, O'Reilly \& Donoghue 2020, Pett \& Heath 2020) it provides an avenue for overcoming uncertainties in fossil placement, which is crucial for older fossils possessing unique phenotypes not observed in 
extant lineages. Another useful tool is the phylomorphospace approach as applied by Schneider et al. (2015) for ferns. In order to obtain reliable age constraints an extensive fossil record is just as important as the detailed knowledge of extant groups obtained by integrative taxonomy which combines DNA datasets with morphological and ecological data to overcome the species delimitation problems posed by morphological homoplasy and cryptic speciation (e.g., Heinrichs et al. 2011a, Dong et al. 2012).

Early Paleozoic microfossils give the first hints of the presence of land plants in the fossil record (e.g., Tomescu et al. 2018) and were employed as maximum age constraints in several divergence time estimates (e.g., Magallón et al. 2013, Feldberg et al. 2014, Laenen et al. 2014, Morris et al. 2017). Some cryptospores that occur from the Ordovician to the Silurian strongly resemble the spores of early diverging liverwort lineages (Renzaglia et al. 2015, Taylor et al. 2017, Tomescu et al. 2018), and also some mesofossils of sporophyte fragments that occur from the Ordovician to the Early Devonian seem related to bryophytes (Edwards et al. 2014).

The earliest macrofossils of Marchantiophyta are from the Middle Devonian and represent thalloid forms, e.g., Metzgeriothallus sharonae Hernick, Landing \& Bartowski (2008: 160), which is considered the oldest liverwort fossil (Hernick et al. 2008, Tomescu et al. 2018). However, there are older macrofossils dating back to the late Silurian or Early Devonian for which an affinity to thalloid lineages has been discussed (refer to Tomescu et al. 2018 for review). Due to the often incomplete preservation, many liverwort-like fossils from sedimentary rock were assigned to fossil genera such as Hepaticites Walton (1925: 565), Thallites Kidst. ex Walton (1925: 564), Marchantites Brongniart (1849: 164) emended Walton (1925: 564), and Metzgeriites Steere (1946: 306). To date, only Metzgeriothallus sharonae and the Late Triassic Marchantites cyathodoides (Townrow 1959: 2) Anderson (1976: 22), which represents the oldest thalloid liverwort fossil with air chambers and shows taxonomic affinities to the crown group Marchantiopsida, have been employed as age constraints (Feldberg et al. 2014, Laenen et al. 2014, Villarreal et al. 2016).

Until the Cretaceous the fossil record is dominated by thalloid forms and mosses. Leafy forms which can be assigned to Jungermanniidae appear sporadically from the early Permian onwards and mostly belong to Jungermannites Göppert (1845: 113) emended Steere (1946: 307), which is defined by the presence of two-or three-ranked leaves and a terminal sporophyte with a four-valved capsule. To date 11-12 species have been accepted (e.g., Berry 1919, Poulsen 1974, Scott 1980, Oostendorp 1987). Only a few of the leafy forms preserved in sedimentary rock can be compared with extant families or orders, including the Late Jurassic Cheirorhiza brittae Krassilov (1970: 134) and the Early Cretaceous Diettertia montanensis Brown \& Robison (1974: 170) (Krassilov 1970, 1973, Brown \& Robison 1974, Krassilov \& Schuster 1984, Schuster \& Janssens 1989).

Uncertain classifications become less obstructive from the mid-Cretaceous onwards when the first amber inclusions appear in the fossil record. Contrary to earlier geologic periods the leafy forms are well represented, while only one thalloid form, Metzgeriites kujiensis T.Katag. in Katagiri \& Shinden (2020: 14), was described from Late Cretaceous Japanese amber. Eight amber deposits yielded leafy liverworts to date, namely 95-100 million-year old (Ma) Alaskan amber (mid-Cretaceous; Heinrichs et al. 2011b), ca. 99 Ma Burmese amber (Kachin amber) from northern Myanmar (mid-Cretaceous; Ross et al. 2010, Shi et al. 2012, Yu et al. 2019), 52 Ma Cambay amber from India (Eocene; Rust et al. 2010), 34-41 Ma Baltic amber from Europe (Eocene; Sadowski et al. 2017, Kasiński et al. 2020), 35-37 Ma Rovno amber from the Ukraine (Eocene; Perkovsky et al. 2010), presumably 24 Ma Bitterfeld amber (Oligocene; Dunlop 2010), 15-20 Ma Dominican amber (Miocene; Penney 2010, Iturralde-Vinet \& MacPhee 2019), and 15-23 Ma Mexican amber (Miocene; Solórzano Kraemer 2010, Serrano-Sánchez et al. 2015). Fossils in amber are mostly three-dimensionally preserved in life-like fidelity and often show minute details that are relevant for classification, e.g., cell shape, cell wall ornamentation, gemmae, or leaf teeth. Most specimens are vegetative gametophyte fragments and reveal only a subset of taxonomically relevant characters, but sometimes fertile structures, such as androecia, gynoecia, or sporophytes are preserved and enhance the reliability of the assignment to extant taxa (e.g., Heinrichs et al. 2018a). Amber fossils usually allow at least a reliable generic assignment which makes them an invaluable source for reconstructing the morphological evolution of Jungermanniidae (Heinrichs et al. 2018a, Renner 2020).

Most amber inclusions belong to the predominantly epiphytic Porellales and especially the families Frullaniaceae and Lejeuneaceae are very diverse. This dominance can be explained by the fact that the resin producing trees grew in humid and warm-temperate to tropical regions (e.g., Penney 2010, Rust et al. 2010, Sadowski et al. 2017) with microclimates very similar to those prevalent in the main geographic distribution of present-day epiphytic liverworts, but also because the epiphytes might have been closer to resin flows.

The epiphytic liverwort diversity of the Baltic, Bitterfeld, and Rovno amber forests was dominated by species of the genus Frullania Raddi (1818: 9), whereas the flora of the Dominican and Mexican amber forests was dominated by representatives of Lejeuneaceae. This is most likely a consequence of the different climates as species of the subcosmopolitan, extant genus Frullania, especially subgen. Trachycolea Spruce (1884:31), seem to be better adapted 
to cool-temperate to warm-temperate climates and much more abundant and diverse in the Holarctic region than the essentially pantropical extant Lejeuneaceae (Schuster 1980, 1992). As compared with Lejeuneaceae, many more species of Frullania also grow under rather dry conditions. In North America Lejeuneaceae are largely restricted to southern Florida whereas Frullania, especially subgen. Trachycolea, is abundant in the temperate part of the continent. In Europe Frullania is a common epiphyte throughout the region whereas Lejeuneaceae are rare. The global distribution and strong drought-adaption of Frullania not only explains its prevalence in temperate amber, but also its scarcity in tropical Dominican and Mexican ambers, because inside some tropical rainforests Frullania is mainly restricted to the canopy and does not grow on the trunks, except in montane cloud forests (e.g., Gradstein et al. 2001). In contrast, these trunks are rich in Lejeuneaceae.

During the past decade, we had the opportunity to investigate the majority of fossil liverworts preserved as amber inclusions. In this checklist, we discuss those liverwort fossils that are suitable as age constraints in molecular phylogenetic reconstructions, with a special focus on amber inclusions.

\section{Material and methods}

The collections in which the amber fossils are housed are listed in Table 1. When necessary, amber specimens were prepared for study following the procedures described by Kettunen et al. (2019). Photographic documentation of the specimens was likewise done as described by Kettunen et al. (2019). All images are digitally stacked photomicrographic composites from up to 80 individual focal planes using the software package HeliconFocus version 6.3.3 Pro.

Nomenclature and classification follow Söderström et al. (2016), except when more recent taxonomical changes are available. This is indicated in the respective justification sections. These sections also include possible assignments of fossils to molecular phylogenies of extant taxa which are based on morphological comparisons and previous divergence time estimations.

TABLE 1. Institutions housing fossil liverworts and their acronyms.

\begin{tabular}{|c|c|}
\hline Acronym & Institution/Collector \\
\hline $\mathrm{AMNH}$ & American Museum of Natural History, New York \\
\hline FEGI-FEB-RAS (ДВГИ) & Far East Geological Institute, Far Eastern Branch of the Russian Academy of Sciences, Vladivostok \\
\hline GPIH & $\begin{array}{l}\text { Geological-Palaeontological Institute and Museum (CeNak) of the University of Hamburg (also } \\
\text { including several specimens formerly belonging to the Carsten Gröhn Amber Collection) }\end{array}$ \\
\hline GRÖHN & $\begin{array}{l}\text { Carsten Gröhn Amber Collection (Amber Research Group, c/o Geological-Palaeontological Institute } \\
\text { and Museum (CeNak) of the University of Hamburg) }\end{array}$ \\
\hline GZG & $\begin{array}{l}\text { Geoscientific Collections of the University of Göttingen (also including the Heinrich Grabenhorst } \\
\text { Amber Collection, the botanical part of the Christel and Hans Werner Hoffeins Amber Collection, and } \\
\text { several specimens formerly belonging to the Patrick Müller Amber Collection) }\end{array}$ \\
\hline HAL-Palaeo & Institut für Geologische Wissenschaften und Geiseltalmuseum, Halle (Saale) \\
\hline LIEDTKE & $\begin{array}{l}\text { Wolfgang Liedtke Amber Collection (Amber Research Group, c/o Geological-Palaeontological Institute } \\
\text { and Museum (CeNak) of the University of Hamburg) }\end{array}$ \\
\hline LUDWIG & $\begin{array}{l}\text { Walter Ludwig Amber Collection (Amber Research Group, c/o Geological-Palaeontological Institute } \\
\text { and Museum (CeNak) of the University of Hamburg) }\end{array}$ \\
\hline MB & Museum für Naturkunde, Leibniz Institute for Evolution and Biodiversity Science, Berlin \\
\hline MÜLLER & $\begin{array}{l}\text { Patrick Müller Amber Collection (Amber Research Group, c/o Geological-Palaeontological Institute } \\
\text { and Museum (CeNak) of the University of Hamburg) }\end{array}$ \\
\hline $\mathrm{NICH}$ & Hattori Botanical Laboratory, Nichinan \\
\hline $\mathrm{NMNH}$ & National Museum of Natural History of the Smithsonian Institution, Washington D.C. \\
\hline NYSM & Paleontology Collection of the New York State Museum, Albany \\
\hline OSU & Poinar Amber Collection (to be deposited at Oregon State University, Corvallis) \\
\hline PB & Nanjing Institute of Geology and Palaeontology \\
\hline SAMC & South African Museum, Cape Town \\
\hline
\end{tabular}


TABLE 1. (Continued)

\begin{tabular}{ll}
\hline Acronym & Institution/Collector \\
\hline SIZK & Schmalhausen Institute of Zoology, Kiev \\
SMNS & Staatliches Museum für Naturkunde, Stuttgart \\
SNSB-BSPG & Bavarian State Collection for Palaeontology and Geology, Munich \\
UMPC & University of Montana Paleontological Collection, Missoula \\
VELTEN & Jürgen Velten Amber Collection (Amber Research Group, c/o Geological-Palaeontological Institute and \\
& Museum (CeNak) of the University of Hamburg) \\
WAR-MZ & Muzeum Ziemi, Warsaw \\
WINTER & Gerhard Winter Amber Collection, Karben \\
WUNDERLICH & Jörg Wunderlich Amber Collection (Amber Research Group, c/o Geological-Palaeontological Institute \\
& and Museum (CeNak) of the University of Hamburg) \\
\hline
\end{tabular}

\section{Results and discussion}

In this checklist we provide information on taxonomy, nomenclature, type material, additional specimens (when present), references, age and stratigraphic level of the fossil material, possible calibration points within the phylogeny of related extant taxa, and justification of these assignments. If a genus includes several fossil species from one deposit, age and stratigraphic level as well as justification refer to all of them. Furthermore, if a genus or family includes several species or species which are currently not suitable for calibration, these are discussed within the scope of families and/ or genera. Collection numbers of fossils that were investigated for the first time in the course of this study are indicated in bold print in the lists of specimens.

\section{Phylum: Marchantiophyta Stotler \& Crand.-Stotl.}

\section{Class: Marchantiopsida Cronquist, Takht. \& Zimm.}

\section{Subclass: Marchantiidae Engl.}

\section{Order: Marchantiales Limpr.}

\section{Family: incertae sedis}

\section{Genus: Marchantites}

\section{Marchantites cyathodoides}

Basionym: Hepaticites cyathodoides.-Holotype: SAMC 13929.

$\equiv$ Eomarchantites cyathodoides (Townrow) R.M.Schust. in Krassilov \& Schuster (1984: 1178), nom. illeg.

Reference: Townrow (1959), plate 1A, B, figs. 1A-J, 2A.

Age and stratigraphic level: 228-237 Ma, Carnian (Late Triassic), Molteno Formation of South Africa.

Calibration: Minimum age of Marchantiidae.

Justification: This Triassic fossil is the oldest thalloid fossil which can be assigned to Marchantiopsida with high confidence (Townrow 1959, Anderson 1976, Krassilov \& Schuster 1984 as Eomarchantites cyathodoides, Oostendorp 1987). It is known only in sterile condition and the thallus is characterized by one row of ventral scales along a midrib, reduced air chambers with pores similar to the extant genus Cyathodium Kunze ex Lehmann (1834: 17) (Townrow 1959), and smooth, dimorphic rhizoids with thick as well as thin walls similar to the extant Neohodgsonia Persson (1954: 40) (Villarreal et al. 2016). Except for the simple thalloid Blasiales and the Sphaerocarpales, comparable characters can be found in the majority of complex thalloids. Heinrichs et al. (2007) employed this fossil to constrain the stem node of the complex thalloids and Cooper et al. (2012), Sun et al. (2014), as well as Villarreal et al. (2016) used the fossil to constrain the stem node of Neohodgsonia and the remaining complex thalloids (Marchantiidae). 


\section{Class: Jungermanniopsida Stotler \& Crand.-Stotl.}

Most fossils resembling the simple thalloid subclasses Metzgeriidae and Pelliidae are found in sedimentary rock and, with the exception of Metzgeriothallus sharonae, are difficult to assign to any extant lineage. The fossil genus Metzgeriites includes seven species ranging in age from the Early Jurassic to the Early Cretaceous, and Metzgeriothallus Schuster (1981: 185) includes two species ranging in age from the Middle Devonian to the late Carboniferous (Katagiri \& Shinden 2020). An exception is Metzgeriites kujiensis, which represents the only amber fossil of a thalloid liverwort to date and has been found in Late Cretaceous Japanese Kuji amber. The fossil is sterile and cells have not been observed, but it shows close morphological affinities to Metzgeriaceae (Katagiri \& Shinden 2020), albeit a classification is difficult and it is therefore not suited as age constraint.

\section{Subclass: incertae sedis}

\section{Order: incertae sedis}

Family: incertae sedis

\section{Genus: Metzgeriothallus}

\section{Metzgeriothallus sharonae}

Holotype: NYSM 17656.

Additional specimens: Gametophytes NYSM 17657-17660, 17662-17664, sporophyte NYSM 17661, approximately 100 unillustrated gametophytes from Cairo quarry (sample CHD-4.6) and 50 gametophytes from Bates Hollow quarry (sample Bat-7.2).

Reference: Hernick et al. (2008), plates I, II.

Age and stratigraphic level: 383-388 Ma, Givetian (late Middle Devonian), Plattekill Formation of the eastern Hamilton Group, New York, USA.

Calibration: Minimum age of Jungermanniopsida/stem Pelliidae.

Justification: Metzgeriothallus was established for fossil liverworts which resemble extant Metzgeria in having thalli with unistratose, entire-margined wings and a multistratose costa. Besides the typical morphology of the genus, $M$. sharonae has a cylindrical sporophyte capsule with four valves. This character supports the assignment to Metzgeriales (Hernick et al. 2008), but similar morphotypes occur not only in Metzgeriales but also in several independent lineages of Jungermanniopsida, namely Metzgeriidae and Pelliidae. Therefore, Feldberg et al. (2014) treated it as the most recent common ancestor of Jungermanniopsida with a minimum age of $385.3 \mathrm{Ma}$, while Laenen et al. (2014) assigned an age of 398 Ma to the stem of Pelliidae.

\section{Subclass: Jungermanniidae Engl.}

\section{Order: incertae sedis}

Family: incertae sedis

\section{Genus: Cheirorhiza Krassilov (1970: 132)}

\section{Cheirorhiza brittae}

Holotype: FEGI-FEB-RAS (ДВГИ) 515-38a.

Additional specimens: Krassilov mentions "about 150" (Krassilov 1970) respective "more than 100" (Krassilov 1973) prepared specimens. In Krassilov (1970) figures for the additional specimens FEGI-FEВ-RАS (ДВГИ) 515-8a (XI 8), 515-11 (XI 4, 5), 515-12 (XII 8, 9), 515-15 (XII 5), 515-18 (XI 7), 515-20 (XI 6), 515-23 (XII 2), 515-28 (XII 6), 515-34 (XII 1), 515-37 (XII 3, 4), 515-42 (XII 10), 515-346 (XII 4) are provided.

References: Krassilov (1970), plates XI 4-8, XII 1-10; Krassilov (1973), plates 41-43; Krassilov \& Schuster (1984), fig. 1.

Age and stratigraphic level: $158 \mathrm{Ma}$, Oxfordian (Late Jurassic), Talynjan (Talynzhan) Formation of Bureya Basin, Iravyi bank of the Bureya river near the mouth of the river Umalta, Amur, Russia. 
Calibration: Minimum age of Jungermanniidae.

Justification: This species represents one of the few fossils from sedimentary rock which are sufficiently well-preserved to allow a detailed reconstruction of the morphology and to interpret it as a leafy liverwort with confidence. It has terminal as well as intercalary branches, complicate bilobed leaves with the small ventral lobe not attached to the dorsal one, reduced underleaves, scattered, supposedly septate rhizoids, and probably capsules (Krassilov 1973, Krassilov $\&$ Schuster 1984). The combination of characters does not allow to assign it to either Porellales or Jungermanniales, therefore it has been employed as a constraint for Jungermanniidae in Heinrichs et al. (2007), Sun et al. (2014), and Cooper et al. (2012).

\section{Order: Jungermanniales H.Klinggr.}

Family: incertae sedis

\section{Genus: Diettertia Brown \& Robison (1974: 170)}

\section{Diettertia montanensis}

Holotype: UMPC 281._-Paratype: UMPC 297.

References: Brown \& Robison (1974), figs. 1-6; Schuster \& Janssens (1989), figs. 1, 2, plate I; Krassilov \& Schuster (1984).

Age and stratigraphic level: $112 \mathrm{Ma}$, early Albian (Early Cretaceous), Kootenai Formation, Great Falls, Cascade County, Montana, USA.

Calibration: Minimum age of crown group Jungermanniales.

Justification: Diettertia montanensis is the second fossil from sedimentary rock that can be clearly identified as a member of Jungermanniidae. With its complicate bilobed, subtransversely inserted leaves, massive stems, elongated cortical cells, and scattered rhizoids it shows strong morphological affinities to Jungermanniales and resembles the isolated genus Schistochila Dumortier (1835: 15) (Krassilov \& Schuster 1984, Schuster \& Janssens 1989, Heinrichs et al. 2007). However, the apparent lack of a ventral merophyte, in combination with the conduplicate bilobed leaves, may also indicate affinities with the Pleuroziales (Schuster \& Janssens 1989). The fossil was assigned as age constraint for Jungermanniales in Heinrichs et al. (2007), Cooper et al. (2012), Sun et al. 2014, and Laenen et al. (2014).

\section{Family: Anastrophyllaceae L.Söderstr., De Roo \& Hedd.}

\section{Genus: Anastrophyllum (Spruce) Stephani (1893: 139)}

\section{Anastrophyllum rovnoi Mamontov, Heinrichs \& Váňa in Mamontov et al. (2015b: 45)}

Holotype: SIZK-K-915-F.

Reference: Mamontov et al. (2015b), figs. 1-6.

Age and stratigraphic level: 35-37 Ma, Priabonian (late Eocene), amber quarry "Pugach", Klesov, Ukraine (Rovno amber).

Calibration: Possible minimum age within Anastrophyllaceae (Anastrophyllum/Gymnocolea).

Justification: This is the first fossil from amber that was identified as a member of the family Anastrophyllaceae and the widely distributed extant genus Anastrophyllum. The assignment is based on the similarity between A. rovnoi and A. ellipticum Inoue (1978: 13) as well as Gymnocolea inflata (Hudson 1778: 511) Dumortier (1835: 17), both members of Anastrophyllaceae. Anastrophyllum rovnoi shares with both A. ellipticum and G. inflata the shape of shoots, the shape of the bilobed leaves, and the leaf cells with clear nodulose thickenings. However, the presence of obliquely inserted and thus nearly flat leaves (versus usually transversely inserted and concave-canaliculate in extant Anastrophyllum species) means the generic assignment of A. rovnoi needs further scrutiny when more completely preserved fossils become available.

Genus: Tetralophozia (R.M.Schust.) Schljakov (1976: 227)

Tetralophozia groehnii Heinrichs, Váňa \& Schäf.-Verw. in Heinrichs et al. (2015b: e0140977 [6]) Holotype: GPIH 4575 (Coll. Gröhn 5827). 
References: Heinrichs et al. (2015b), figs. 2, 3; Heinrichs et al. (2018a), plate II(2).

Age and stratigraphic level: $34-41 \mathrm{Ma}$, Priabonian-Bartonian (Eocene), Baltic region.

Calibration: Minimum age of Tetralophozia.

Justification: This species represents the first fossil evidence of Tetralophozia, a small genus of four extant species which are distributed in Asia, Africa, and the Holarctics (e.g., Paton 1999, Schuster 2002). The fossil shows the typical 4-lobed leaves with toothed margins and only differs from extant representatives of the genus by the regular dentation and the presence of teeth with 1-4(-5) celled uniseriate tips (Heinrichs et al. 2015b). Divergence time estimates provide evidence of an Eocene origin of Tetralophozia and are in good accordance with the age of the fossil (Feldberg et al. 2013, 2014). The sterile condition limits the comparison with the extant diversity, but $T$. groehnii is morphologically very similar to extant species and might even belong to the crown group. Hence, it provides a reliable minimum age constraint for the genus.

\section{Family: Calypogeiaceae Arnell}

This family is represented by two fossil species of the genera Calypogeia Raddi (1818: 31) and Metacalypogeia (S.Hatt.) Inoue (1959: 231) in Baltic and Bitterfeld amber. Only the Calypogeia fossil provides a reliable age constraint, while the taxonomic assignment of the Metacalypogeia fossil is unclear.
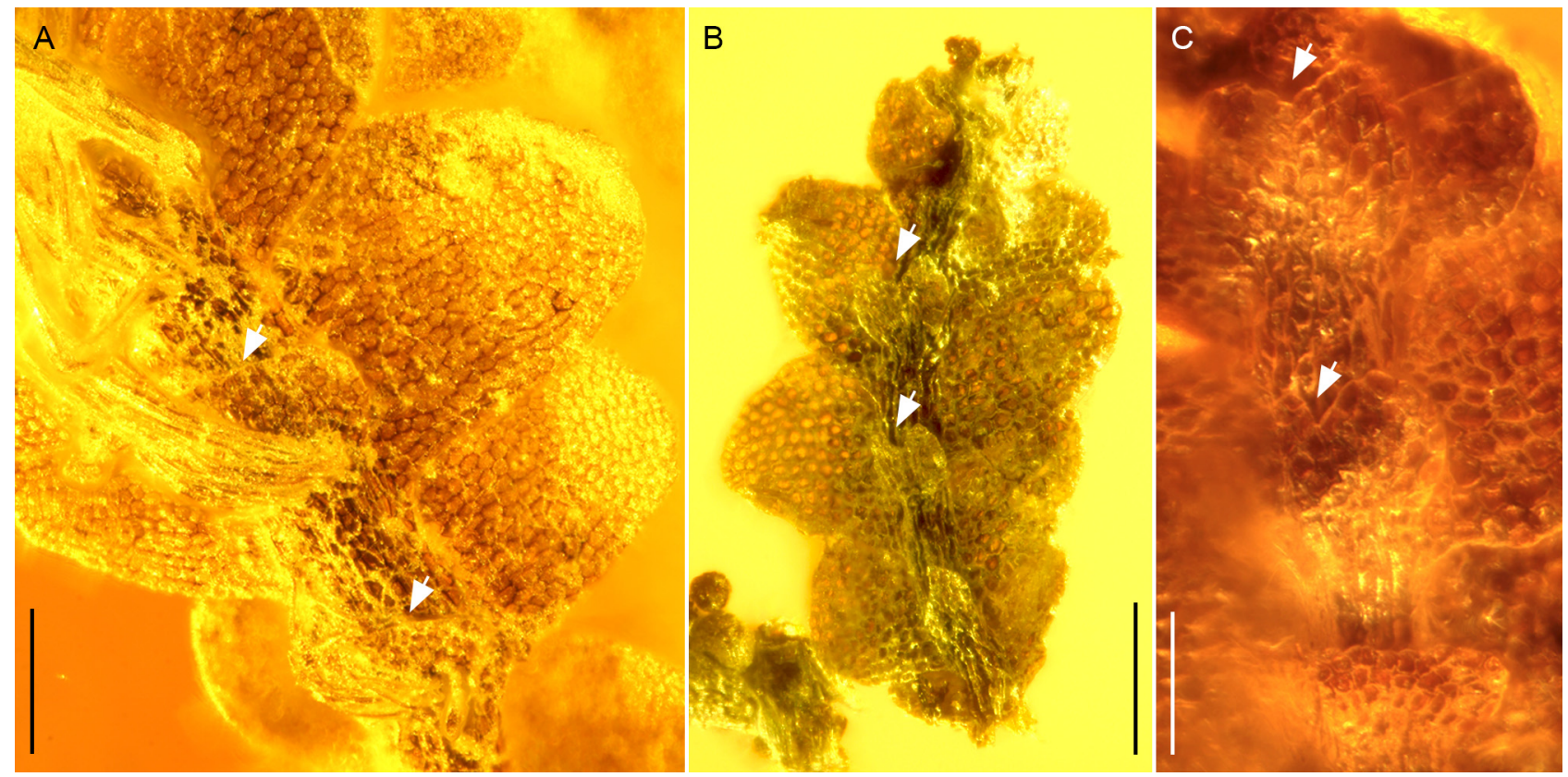

FIGURE 1. Calypogeiaceae. A. Metacalypogeia baltica, MB.Pb.1996/1355a (holotype) from Baltic amber, ventral view with underleaves and rhizoid bundles. B, C. Calypogeia stenzeliana. B. MB.Pb.1997/3i (holotype) from Bitterfeld amber, overview ventral. C. GRÖHN 2076 from Baltic amber, ventral view with underleaves. White arrows indicate underleaves. Scale bars: A, B=200 $\mu \mathrm{m}, \mathrm{C}=100 \mu \mathrm{m}$.

Metacalypogeia baltica Grolle (1999: 88) has been described from Baltic amber only (Fig. 1A). Extant Metacalypogeia is differentiated from Calypogeia by cuticular structure (smooth vs. smooth to finely verrucose), gemmae production (lacking vs. present), oil-bodies, and the capsule valves (e.g., Hong 1990), whereas the latter three characters have not been observed in the fossil material. The first character is variable as also some Calypogeia species can have a smooth cuticle. Not all fossils of C. stenzeliana Grolle (1985a: 41) show a distinctly striolate cuticle and the overall high similarity of M. baltica and C. stenzeliana might render them conspecific (Fig. 1B, C). The only clear difference between the two fossil species is the furcation of underleaves, but these have proven to be variable in extant species, especially between gemmiparous shoots and the main shoots (Paton 1999). One example is $C$. neesiana (Massalongo \& Carestia 1880: 351) Müll.Frib. in Loeske (1905: 320) which is characterized by heterogenous underleaves, which are entire to retuse to emarginate to bilobed. Gemmiparous shoots of this species often have bidentate lateral leaves and more deeply bilobed underleaves than on the main shoot. The underleaves can also vary in having additional lateral teeth. Another example of morphological heterogeneity within one species is C. sphagnicola 
(Arnell \& J.Perss. in Arnell 1902: 26) Warnst. \& Loeske in Loeske (1905: 320) which has shoots with subacute to narrowly rounded lateral leaves as well as shoots with retuse lateral leaves.

\section{Genus: Calypogeia}

Calypogeia stenzeliana; Fig. 1B, C

Holotype: MB.Pb.1997/3i (Coll. Grolle F/1i), Bitterfeld amber-—Paratype: MB.Pb.1997/3k (Coll. Grolle F/1k), Bitterfeld amber.

Additional specimens: Baltic amber: GRÖHN 2076 (det. Metacalypogeia baltica in Grolle \& Meister 2004b), 2092; MB.Pb.1996/1356 (Coll. Hoffeins). Bitterfeld amber: MB.Pb.1997/3j (Coll. Grolle F/1j).

References: Grolle (1985a), Abb. 1a-d, Tafeln I, II; Grolle \& Meister (2004b), plate 2a-d; Heinrichs et al. (2018a), plate I(5).

Age and stratigraphic levels: 34-41 Ma, Priabonian-Bartonian (Eocene), Baltic region; and $24 \mathrm{Ma}$, Chattian (late Oligocene), Bernsteinschluff Horizon in the upper part of the Cottbus Formation of the Goitzsche mine, Bitterfeld, Germany.

Calibration: Minimum age of Calypogeia.

Justification: Apart from the holotype, several well-preserved specimens of C. stenzeliana are known from Baltic and Bitterfeld amber and were all investigated for this study. All specimens are known only in sterile condition (Grolle 1985a, Grolle \& Meister 2004b), however, the holotype (Fig. 1B) and specimens MB.Pb.1996/1356 as well as GRÖHN 2092 and 2076 are exquisitely preserved and show a wide array of characters, which are sufficient for a reliable generic assignment and in good accordance with the morphology of extant Calypogeia, including the incubous, entire to shallowly bilobed lateral leaves, which can be rather variable on one shoot, the mostly bilobed underleaves, and in the latter specimen also the tapering of the shoot with leaves becoming successively smaller and more distant (e.g., Hong 1990, Paton 1999, Schuster 2000). One specimen (GRÖHN 2076) was identified as Metacalypogeia baltica in Grolle \& Meister (2004b) but is here re-identified as C. stenzeliana based on the presence of bifid underleaves (Fig. 1C). It is larger than the holotype with shoots up to $520 \mu \mathrm{m}$ wide, the stem up to $90 \mu \mathrm{m}$ wide, a ventral merophyte ca. 6 cells wide, and lateral leaves 250-300 $\mu \mathrm{m}$ long $\times 230-250 \mu \mathrm{m}$ wide. The apices of lateral leaves are rounded to truncate to retuse. The leaf cells are quadrate to rectangular and 20-25 $\mu \mathrm{m}$ long $\times 18-25 \mu \mathrm{m}$ wide. Underleaves are $0.8-1 \times$ wider than the stem, $100-120 \mu \mathrm{m}$ long $\times 130-160 \mu \mathrm{m}$ wide, ca. $1.3 \times$ wider than long, and bilobed to ca. $0.25-0.3$. The sinus is widely V-shaped, and the underleaf lobes are ca. 4 cells wide at base and 2(-3) cells long with an obtuse apex.

The species is resembling C. suecica (Arnell \& J.Perss. in Arnell 1902: 29) Müller (1904: 224) from temperateboreal Europe and North America (Grolle \& Meister 2004b). However, a more elaborate discussion of its affinities to extant representatives is presently difficult because fertile structures are lacking and the inner taxonomy of Calypogeia is still not sufficiently known (Söderström et al. 2016). Species are characterized by ecologically induced morphological variation as well as cryptic species complexes (Schuster 1969, Paton 1999, Buczkowska et al. 2018).

Calypogeia stenzeliana has already been employed as age constraint in several analyses (Heinrichs et al. 2007, Cooper et al. 2012, Feldberg et al. 2014, Laenen et al. 2014, Sun et al. 2014). In Feldberg et al. (2014) and Laenen et al. (2014) it was assigned as most recent common ancestor of the Calypogeia crown group. These assignments resulted in an estimated mean age for the genus of 40.03 Ma respective median ages of 44.78-71.23 Ma. The incomplete fossil material does not justify any assignment within the extant crown group of Calypogeia, though the morphology of $C$. stenzeliana suggest close affinities.

\section{Family: Cephaloziaceae Mig.}

This family is represented by two fossil species of the genera Odontoschisma (Dumort.) Dumortier (1835: 19) and Cephalozia (Dumort.) Dumortier (1835: 18) in Baltic and Bitterfeld amber. The taxonomic assignment of the latter is currently difficult. Cephalozia veltenii Katagiri (2015:348) is very similar to the stolons or tapering shoots with reduced leaves which are frequently produced by $O$. dimorpha (Caspary 1887: 2) Heinrichs, K.Feldberg, Váña \& Schäf.-Verw. in Feldberg et al. (2017: 151), but it can be distinguished from the latter by several characters (Katagiri 2015), e.g., the presence of a stem hyalodermis and the obliquely to transversely inserted leaves which usually do not reach the midline of the dorsal stem surface. The use of $C$. veltenii as age constraint is currently not advisable, not only because of the lack of fossil material, but also because of the taxonomical uncertainties in extant Cephalozia (e.g., Feldberg et al. 2016). 


\section{Genus: Odontoschisma}

\section{Odontoschisma dimorpha; Fig. 2A-C}

Basionym: Jungermannia dimorpha Casp.-Holotype: MB.Pb.1979/687a (Coll. Künow 144a), Baltic amber.

$\equiv$ Cephaloziella dimorpha (Casp.) Grolle (1980a: 184)

$\equiv$ Cylindrocolea dimorpha (Casp.) Grolle in Grolle \& Meister (2004b: 14)

Additional specimens: Baltic amber: GPIH BB1584, 4575 (Coll. Gröhn 5827); GRÖHN 2015, 2038, 2082, 5834, 7622; GZG.BST.21957 (Coll. Hoffeins 5-43), GZG.BST.21959 (K7.319); MB.Pb.1979/654 (Coll. Künow 95), MB.Pb.1979/688 (Coll. Künow 145), MB.Pb.1979/689 (Coll. Künow 146), MB.Pb.1979/708 (Coll. Künow 165a), MB.Pb.1979/687b (Coll. Künow 144b), MB.Pb.1996/1357 (Coll. Rasmussen; det. Lophozia kutscheri in Grolle \& Meister 2004b); SNSB-BSPG 1958 VIII 44 (Bachofen-Echt amber collection P44), 1958 VIII 95 (BachofenEcht amber collection P95). Bitterfeld amber: GZG.BST.21958 (Coll. Hoffeins 930-3), GZG.BST.22049 (Coll. Grabenhorst Le-49), GZG.BST.22050 (Coll. Grabenhorst Le-51), GZG.BST.22051 (Coll. Grabenhorst Le58), GZG.BST.22052 (Coll. Grabenhorst Le-73), GZG.BST.22053 (Coll. Hoffeins 13-2); MB.Pb.1997/2 (Coll. Kutscher H006), MB.Pb.1997/12 (ser. 8/2a), MB.Pb.1997/16 (Coll. Kutscher M 8/6), MB.Pb.1997/24 (Coll. Grolle M 10/5), MB.Pb.1997/36 (Coll. Grolle M 12/8), MB.Pb.1997/37 (Coll. Grolle M 12/9), MB.Pb.1997/44a (Coll. Grolle $\mathrm{M}-14 / 5 \mathrm{a})$.

References: Caspary (1887), Tafel I Bild 3, 4 as Jungermannia dimorpha; Caspary \& Klebs (1907), Tafel VII Bild 38, 38a-d as Jungermannia dimorpha; Grolle (1980a), Abb. 1a-f, Tafeln XIII, XIV, XVIc-e as Cephaloziella dimorpha; Grolle (1989), Abb. 1e as Cephaloziella dimorpha; Grolle \& Meister (2004b), plates 3, 4a-f as Cylindrocolea dimorpha; Feldberg et al. (2017), figs. 1, 2; Heinrichs et al. (2018a), plate I(6).

Age and stratigraphic level: 34-41 Ma, Priabonian-Bartonian (Eocene), Baltic region; and $24 \mathrm{Ma}$, Chattian (late Oligocene), Bernsteinschluff Horizon in the upper part of the Cottbus Formation of the Goitzsche mine, Bitterfeld, Germany.

Calibration: Minimum age of Odontoschisma sect. Iwatsukia (Kitagawa 1964: 178) Gradstein, Aranda \& Vanderpoorten (2014: 232).

Justification: Odontoschisma dimorpha is the most abundant representative of Jungermanniales in Baltic as well as Bitterfeld amber, but due to the scarcity of distinct underleaves its true taxonomical affinities were unknown for a long time. The assignment is also complicated by the mostly sterile condition of fossil specimens. Androecia are present in the holotype (Fig. 2A) and one additional specimen (SNSB-BSPG 1958 VIII 44), but gynoecia as well as sporophytes are still unknown. The species is characterized by a very heterogeneous morphology (e.g., Grolle \& Meister 2004b, Feldberg et al. 2017) which includes vigorous shoots with large, imbricate lateral leaves and well developed bifid underleaves but also stoloniform and tapering shoots with strongly reduced lateral leaves and reduced to lacking underleaves (compare Fig. 2A-C). This combination of characters allows for an assignment to the small tropical genus Iwatsukia which has been included in Odontoschisma as sect. Iwatsukia based on molecular phylogenetic evidence (Vilnet et al. 2012, Aranda et al. 2014). The fossil is somewhat similar to the extant Odontoschisma jishibae (Stephani 1924: 437) L.Söderstr. \& Váňa in Váňa et al. (2013b: 13) and differs from most other species of Odontoschisma in having bifid leaves and evenly thickened cell walls without trigones (compare Gradstein \& Ilkiu-Borges 2015, fig. 9).

The taxonomical affinities of $O$. dimorpha have thoroughly been discussed in Feldberg et al. (2017) who confirmed the suitability as an age constraint for Odontoschisma sect. Iwatsukia. Placement of the fossil in Cephaloziaceae profoundly affects divergence time estimates. The reclassification in Feldberg et al. (2017) concurs with hypotheses on the divergence times of Cephaloziaceae derived from DNA sequence data that provide evidence of a late Early Cretaceous to early Eocene age of the Odontoschisma crown group and an origin of sect. Iwatsukia in the Late Cretaceous to Oligocene.

\section{Family: Cephaloziellaceae Douin}

This family is represented by two fossil species which could provide minimum age constraints for the genera Cephaloziella (Spruce) Schiffner (1893: 98) and Protolophozia (R.M.Schust.) Schljakov (1979: 204). However, both genera are taxonomically largely unresolved, and assignments have to be thoroughly evaluated. 


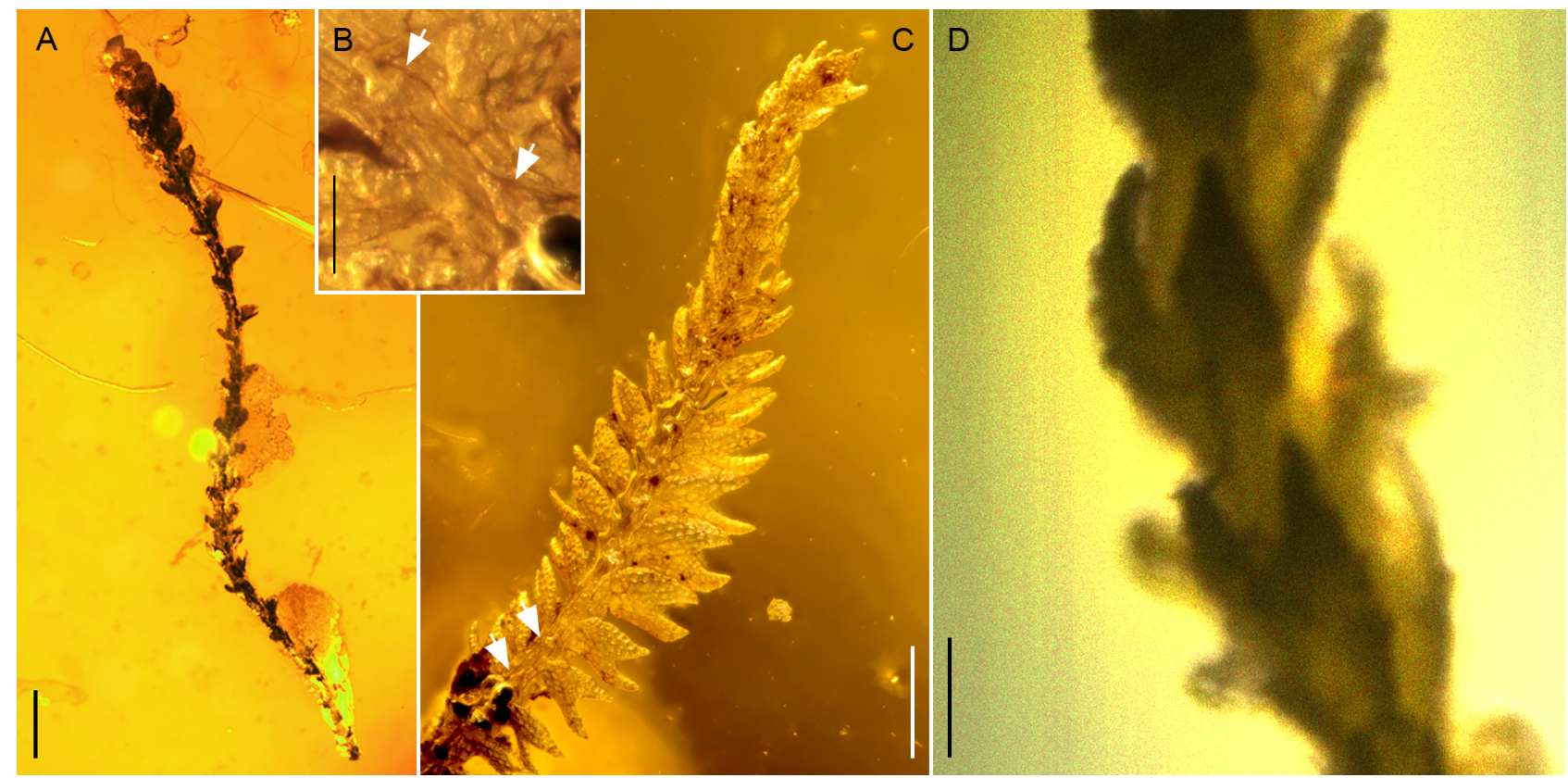

FIGURE 2. Cephaloziaceae and Cephaloziellaceae. A-C. Odontoschisma (sect. Iwatsukia) dimorpha. A. MB.Pb.1979/687 (holotype) from Baltic amber, overview in dorso-lateral view with androecium at shoot tip. B, C. MB.Pb.1996/1357 from Baltic amber. B. Ventral view with reduced underleaves. C. Overview ventral with tapering shoot apex. D. Cephaloziella nadezhdae, SIZK-K-24755-F (holotype) from Baltic amber in lateral view. White arrows indicate underleaves. Scale bars: $A=500 \mu \mathrm{m}, \mathrm{B}=50 \mu \mathrm{m}, \mathrm{C}=200 \mu \mathrm{m}, \mathrm{D}=20 \mu \mathrm{m}$.

\section{Genus: Cephaloziella}

Cephaloziella nadezhdae Mamontov, Heinrichs \& Váňa in Mamontov et al. (2015c: 293); Fig. 2D Holotype: SIZK-K-24755-F.

Reference: Mamontov et al. (2015c), figs. 1-18.

Age and stratigraphic level: 35-37 Ma, Priabonian (late Eocene), amber quarry "Pugach", Klesov, Ukraine (Rovno amber).

Calibration: Minimum age of Cephaloziella.

Justification: The sterile shoot fragment is the first representative of this genus in amber. The small size, the basally ciliately toothed leaves, the distinctly mammillose cells, and the presence of gemmae (Fig. 2D) differentiate this specimen clearly from Cephalozia veltenii and Odontoschisma dimorpha and allow a reliable assignment to Cephaloziella, a taxonomically largely unresolved genus characterized by its small size, the bilobed leaves, and often reduced underleaves (e.g., Schuster 1980, 2002, Söderström et al. 2016). Species delimitation in extant Cephaloziella is very difficult, especially when only sterile material is at hand (Paton 1999). The species is most similar to representatives of the Holarctic and Oceanic subgen. Schizophyllum Müller (1912: 110), while the small leaf cells (only 5-8 $\mu \mathrm{m}$ ) are reminiscent of C. microphylla (Stephani 1908: 513 [343]) Douin (1920: 59) (Mamontov et al. 2015c). The sterile condition makes an assignment to extant lineages of Cephaloziella difficult, but it provides a minimum age for the genus.

\section{Genus: Protolophozia}

Protolophozia kutscheri (Grolle) Heinrichs, Feldberg, Mamontov, Schäfer-Verwimp \& Schmidt, comb. nov.; Fig. 3

Basionym: Lophozia kutscheri Grolle in Grolle \& Meister (2004a: 79).--Holotype: MB.Pb.1996/1338, Bitterfeld amber.

Additional specimens: Baltic amber: GRÖHN 5803, 5843. Bitterfeld amber: MB.Pb.sn (Coll. Kutscher Ku-98H03/ a); GZG.BST.22054 (Coll. Grabenhorst Le-22), GZG.BST.22055 (Coll. Grabenhorst Le-42), GZG.BST.22056 (Coll. Hoffeins 945). 
References: Grolle \& Meister (2004a), figs. 1, 2 as Lophozia kutscheri; Grolle \& Meister (2004b), plate 13 as Lophozia kutscheri; Heinrichs et al. (2018a), plate II(1) as Lophozia kutscheri.

Age and stratigraphic level: 34-41 Ma, Priabonian-Bartonian (Eocene), Baltic region; and $24 \mathrm{Ma}$, Chattian (late Oligocene), Bernsteinschluff Horizon in the upper part of the Cottbus Formation of the Goitzsche mine, Bitterfeld, Germany.

Calibration: Possible minimum age of Protolophozia.

Emended description: Shoots red brown, about $5 \mathrm{~mm}$ in length and $0.7-1.0(-1.1) \mathrm{mm}$ wide [GRÖHN 5843 only visible in lateral view; Fig. 3D, E], holotype unbranched and accompanied by a few much smaller and simplified shoot fragments (three \pm parallel to its base and a single across apex; Fig. 3A, B), one with bifid leaves near the base and trifid leaves near the apex; specimen GRÖHN 5843 with flagelliform branch much thinner than main shoot (Fig. 3E), $0.15-0.35 \mathrm{~mm}$ wide with leaves; shoot apex distinctly turned upwards. Stem dark red brown, round to dorsoventrally flattened, $170-180 \mu \mathrm{m}$ in diameter, cortical cells short to long rectangular, walls pale, equally moderately thickened, lumen dark red brown; on flagelliform branch $30-50 \mu \mathrm{m}$ in diameter. Rhizoids colorless, numerous, irregularly scattered or forming a continuous row along ventral side of stem up to apex. Ventral leaf free zone ca. 2 cells broad. Lateral leaves imbricate to loosely contiguous, widely patent, in dorsal half \pm transversely inserted, in ventral half with \pm oblique, succubous, and straight insertion line (Fig. 3A, D, E), slime papillae probably present on coarse teeth near leaf base; leaves obtrapeziform, 400-600 $\mu \mathrm{m}$ long $\times 330-400 \mu \mathrm{m}$ wide, widest part below bases of lobes, slightly canaliculate-concave (in dorsal view), often subkeeled near sinus base, on lower parts of shoots often equally bifid, on upper parts mostly unequally $3(-4)$-lobed, divided up to $0.3 \times$ the leaf length, the median leaf lobe large, the other two equal in size or one of them distinctly smaller, sometimes even reduced to a spine; lobes triangular to broadly lanceolate, somewhat diverging, almost flat, at base 6-8 cells wide, apex acute to \pm acuminate with a short to long triangular tip cell, or if apex gemmiferous then somewhat obtuse; dorsal leaf margin slightly and regularly curved, distinctly upturned, base somewhat turned inwards, slightly but distinctly ampliate, but not overlapping, not decurrent; ventral leaf margin slightly and regularly curved, flat, base slightly ampliate, not overlapping, not decurrent; sinus variable, wide to narrow, with rounded base, mostly gibbous. Leaf cells somewhat irregular, pentagonal or hexagonal, mostly isodiametric, some \pm elongated, 17-21 $\times 17-34 \mu \mathrm{m}$ (sometimes elongated to $45 \mu \mathrm{m}$ near ventral base), walls pale, moderately equally thickened, almost without trigones, lumen red brown; cuticle faintly punctatepapillose. Lateral leaves on flagelliform branch contiguous to distant, transversely to slightly obliquely inserted, ovate to rectangular, $70-110 \mu \mathrm{m}$ long $\times 50-60 \mu \mathrm{m}$ wide, bifid to ca. $0.5 \times$ their length, lobes lanceolate, acute, $2-3$ cells wide at base and 3-4 cells long, incl. single short tip cell. Underleaves absent in greater part of type specimen, only in its most vigorous middle three rather large underleaves visible (Fig. 3 C), $0.5 \times$ the lateral leaf length, variably shaped, lanceolate-ovate to bifid, irregularly laciniate-spinose, spines forward directed [seemingly missing or obscured by rhizoids in GRÖHN 5843]. Asexual reproduction by gemmae arising in clusters at tips of leaf lobes, \pm intact clusters present at shoot apex of type. Otherwise gemmae apparently dispersed and hence merely remnants of clusters on older leaves; gemmae angular, colorless or similar in color to leaf lobes, number of cells not clearly visible. Sterile.

Justification: The fossil species does not conform to the current circumscription of Lophoziaceae nor the genus Lophozia (Dumort.) Dumortier (1835: 17) (Söderström et al. 2016), therefore, the taxonomy is re-evaluated here. Based on molecular phylogenies and morphological studies, the taxonomy of Lophoziaceae underwent fundamental changes in recent years (De Roo et al. 2007, Vilnet et al. 2008, 2010, Váňa et al. 2013a, Bakalin \& Vilnet 2019). Species included in Lophozia lack flagelliform branches and stolons, are characterized by transversely to subhorizontally inserted, 2(-3-4)-lobed leaves, and underleaves are mostly lacking or simple and lanceolate (Schuster 1969, 2002). Especially the latter character distinguishes the type of $L$. kutscheri from extant representatives; it has irregularly shaped lanceolate-ovate to bifid, laciniate-spinose underleaves which can also be lacking (Fig. 3C; also compare Grolle \& Meister 2004a, b). The new specimen from Baltic amber (GRÖHN 5843) is in good accordance with the type and provides additional characters which facilitate the taxonomic assignment. It has a flagelliform branch, a character not occurring in Lophozia. The branch insertion seems to be lateral but an affiliation to the lateral leaves is not clearly visible. It might be lateral-intercalary and is much thinner than main shoot. 


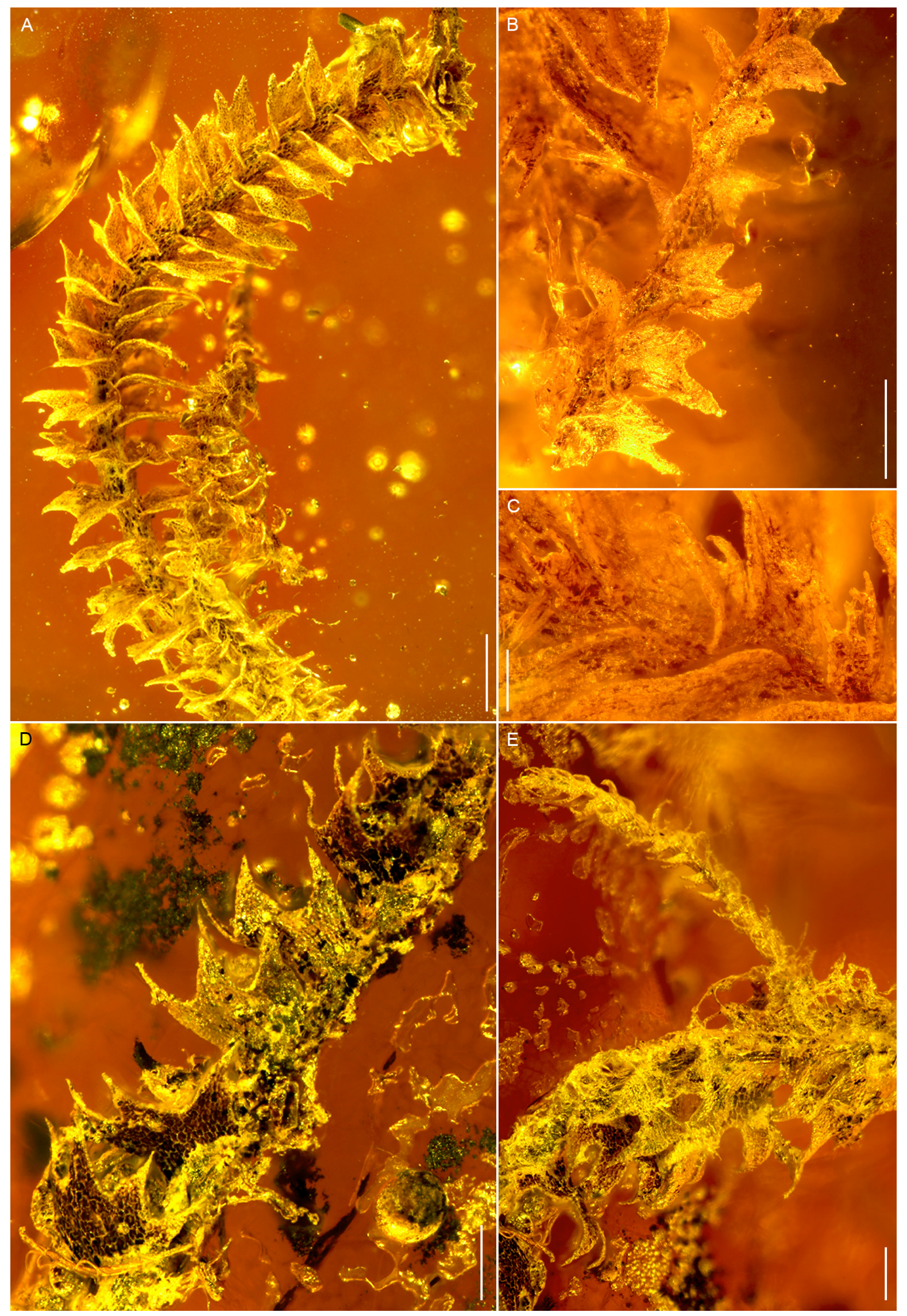

FIGURE 3. Cephaloziellaceae. A-E. Protolophozia kutscheri, comb. nov. A-C. MB.Pb.1996/1338 (holotype) from Bitterfeld amber. A. Dorsal view of large shoot (holotype) with trifid leaves accompanied by smaller shoots with bifid leaves. B. Detail of smaller shoot in ventro-lateral view. C. Underleaves from holotype. D, E. GRÖHN 5843 from Baltic amber in lateral view. D. Middle part of shoot with scattered rhizoids. E. Flagelliform branch. Scale bars: A=500 $\mu \mathrm{m}, \mathrm{B}, \mathrm{D}, \mathrm{E}=200 \mu \mathrm{m}, \mathrm{C}=100 \mu \mathrm{m}$. 
Species with trifid leaves are rare in extant Lophozia. They can occur in L. ciliata Damsh., L.Söderstr. \& H.Weibull in Söderström et al. (2000: 3) which also has relatively large lanceolate to 3-lobed, dentate to laciniate underleaves. The plant differs from the fossil species in the form of the ovate-rectangular to obovate lateral leaves, which can be bifid up to $0.5 \times$ their length and are generally longer than wide with more or less straight margins which are gradually narrowed toward the leaf base. The 3-lobed leaves of the fossil are wider than long, and their margins are curved and ampliate. Furthermore, L. ciliata has specialized flagelliform shoots with reduced leaves which produce gemmae at their apices. Other genera of Lophoziaceae with occasionally to frequently 3-lobed leaves are Heterogemma (Jørg.) Konstantinova \& Vilnet (2009: 67), Trilophozia (R.M.Schust.) Bakalin (2005: 34), and Tritomaria Schiffn. ex Loeske (1909: 13), all of which lack underleaves.

3(-4)-lobed leaves are a highly homoplastic character and occur in several families of Jungermanniales: in Anastrophyllaceae [e.g., Barbilophozia Loeske (1908: 37), Neoorthocaulis Söderström, De Roo \& Hedderson (2010: 49), Orthocaulis Buch (1932: 293), Schljakovianthus Konstantinova \& Vilnet (2009: 66)], in Scapaniaceae [e.g., Pseudotritomaria Konstantinova \& Vilnet (2009: 66), Schistochilopsis (N.Kitag.) Konstant. in Konstantinova \& Vasiljev (1994: 125)], and in Cephaloziellaceae [Protolophozia].

Though the form of the lateral leaves is superficially similar, Barbilophozia differs from L. kutscheri in several characters: the leaf insertion is generally oblique, the lateral leaves are basally armed with postical teeth or cilia, and the underleaves are larger, more deeply bifid, and ciliate. More similar is Neoorthocaulis, which is characterized by (2)3(-4)-lobed leaves (divided up to $0.4 \times$ their length) with a revolute sinus and few or no cilia on the postical margin. The underleaves are lacking to large and bifid, have few lateral teeth or cilia (Söderström et al. 2010), and clearly differ from the fossil with its variably shaped, lanceolate-ovate to bifid, and irregularly laciniate-spinose underleaves. Furthermore, Neoorthocaulis has only few rhizoids while at least the fossil specimen GRÖHN 5843 has dense, scattered rhizoids. Orthocaulis clearly differs in having small and unlobed underleaves while Schljakovianthus has more deeply and mostly 4-lobed (up to $0.6 \times$ their length) lateral leaves with basal teeth, no gemmae, and bilobed underleaves which are more deeply bifid and have distinct cilia only near their base. Pseudotritomaria and Schistochilopsis can also have 2-3-lobed leaves, but both genera differ from the fossil by lacking underleaves entirely.

Protolophozia is a small, mainly Austral genus which is still insufficiently known (Váña et al. 2013a). It was treated either as genus or as a subgenus of Lophozia (Schuster 2002). Based on molecular phylogenetic evidence the generic status is currently accepted and it was tentatively transferred to Cephaloziellaceae (Vilnet et al. 2010, Söderström et al. 2016). The genus lacks terminal branching, leaves are 2-3(-4)-lobed, underleaves and gemmae are present. The extant Protolophozia lancistipa (Grolle 1971: 230) Váňa \& L.Söderstr. in Váňa et al. (2013a: 51), P. crispata (Schuster 1968: 474) Váňa \& L.Söderstr. in Váňa et al. (2013a: 51), and P. verruculosa (Schuster 1978: 242) Váňa \& L.Söderstr. in Váňa et al. (2013a: 52) have lateral intercalary branches from the leaf axils, intermingled 2-and 3-lobed leaves, cells with weak trigones, and conspicuous, irregularly shaped, often bifid underleaves. The circumscription of Protolophozia is in good accordance with the morphology of the fossil. The form of the 2-3-lobed lateral leaves, the rather irregularly shaped underleaves with only few teeth or cilia and the presence of a flagelliform branch fit the description of this genus, therefore, we transfer Lophozia kutscheri to Protolophozia.

Lophozia kutscheri has been employed as age constraint in several studies (Feldberg et al. 2013, 2014, Laenen et al. 2014). Feldberg et al. (2014) assigned it to a broadly circumscribed genus Lophozia (including Barbilophozia) which resulted in an estimated mean age of $43.32 \mathrm{Ma}$. Laenen et al. (2014) assigned it to Lophozia and estimated median ages of 34.22-45.92 Ma. A re-assignment that reflects the taxonomical changes of extant genera is currently difficult because only one species of Protolophozia, P. elongata (Stephani 1902: 41) Schljakov (1979: 204), has been included in a molecular phylogeny.

\section{Family: Geocalycaceae H.Klinggr.}

\section{Genus: Geocalyx Nees (1833b: 97)}

\section{Geocalyx heinrichsii Katagiri (2018: 113)}

Holotype: NICH-492966.

Reference: Katagiri (2018), fig. 1.

Age and stratigraphic level: $34-41 \mathrm{Ma}$, Priabonian-Bartonian (Eocene), Baltic region.

Calibration: Minimum age of Geocalyx.

Justification: This species is the only representative of this monogeneric family in amber. The obliquely inserted, 
succubous lateral leaves, the large bifid underleaves, and the presence of gemmiferous, microphyllous shoots are in good accordance with extant representatives (Katagiri 2018). It is similar to the extant Asian species G. lancistipulus (Stephani 1922: 281) Hattori (1953: 234), but the sterile condition prevents a more specific comparison.

To date, this species has not been employed as an age constraint. It could provide a minimum age for the crown group of Geocalyx which is molecularly and morphologically well defined (e.g., Shaw et al. 2015). The stem node of Geocalyx has a mean age of 169.31 Ma in Feldberg et al. (2014), while the median ages for the genus in Laenen et al. (2014) are 74.23-96.93 Ma. Considering the confidence intervals, the latter estimate is in good accordance with the fossil material.

\section{Family: Lepidoziaceae Limpr.}

\section{Genus: Bazzania Gray (1821: 704)}

Bazzania has a largely tropical and subtropical distribution range with expansions into the Arctic and sub-Antarctic regions. The genus includes ca. 100 extant as well as two fossil species and the taxonomy has been intensively studied in recent years (e.g., Zhou et al. 2012, Bakalin 2016, Cheah \& Yong 2016, Gradstein 2017, Khotimperwati et al. 2018, Meagher 2019). Based on new fossil material we emend the description of B. polyodus (Caspary 1887: 4) Grolle (1980a: 188) from Baltic and Bitterfeld amber, which is well suited as age constraint.
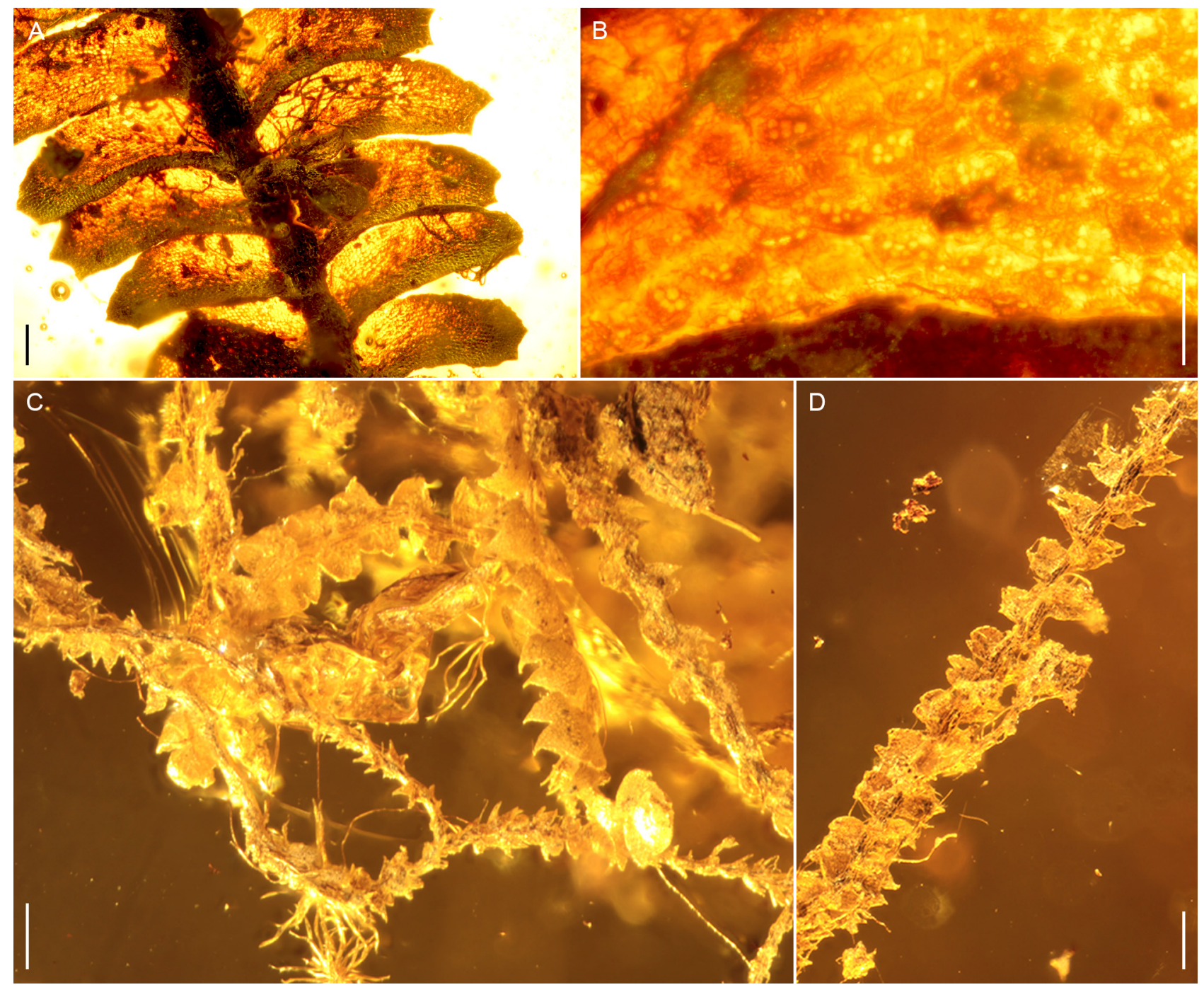

FIGURE 4. Lepidoziaceae. A, B. Bazzania oleosa, SMNS do-4100-M-1 (holotype) from Dominican amber. A. Ventral view with broken Bazzania-type branch (middle). B. Leaf cells with oil-bodies. C, D. Bazzania polyodus, GRÖHN 5844 from Baltic amber. C. Shoot system of large, typical shoots and stoloniform shoots. D. Stoloniform shoot in ventral view. Scale bars: A, C, D=200 $\mu \mathrm{m}, \mathrm{B}=50 \mu \mathrm{m}$. 
Bazzania oleosa Grolle in Grolle \& Braune (1988: 102) from Dominican amber is only known from the sterile holotype. Though the fossil is exquisitely preserved and allows a detailed study of many diagnostically important characters, e.g., the ventral Bazzania-type branches (Fig. 4A) and the leaf cells with suspected oil-bodies preserved (Fig. 4B), it is currently not possible to assign it to any lineage within the crown group. It shows similarities to $B$. hookeri (Lindenb. in Gottsche et al. 1845a: 226) Trevisan (1877: 414) and the common Neotropical B. longistipula (Lindenb. in Gottsche et al. 1845a: 228) Trevisan (1877: 415) but also differs in several important characters and might not be closely related (Grolle \& Braune 1988, Gradstein 2017).

Many of the vegetative characters in extant Bazzania are variable and may be affected by environmental factors (e.g., Gradstein 2017), but given extensive molecular datasets combined with morphological analyses, it might yet be possible to assign both fossil species to a lineage within the crown group.

\section{Bazzania polyodus; Fig. 4C, D}

Basionym: Lophocolea polyodus Casp.-Holotype: MB.Pb.1979/690 (Coll. Künow 147), Baltic amber.

Additional specimens: Baltic amber: GPIH 4327; GRÖHN 443, 2077, 5844; VELTEN 0017c. Bitterfeld amber: LUDWIG Bi2005; MB.Pb.1996/1339 (Coll. Teuber).

References: Caspary (1887), Tafel I Bild 12, 13 as Lophocolea polyodus; Caspary \& Klebs (1907), Tafel VI Bild 36, 36a-c as Lophocolea polyodus; Grolle (1980a), Abb. 1g-k, Tafel XV, XVIa, b; Grolle \& Meister (2004b), plate 1; Heinrichs et al. (2018a), plate I(1).

Age and stratigraphic level: 34-41 Ma, Priabonian-Bartonian (Eocene), Baltic region; and $24 \mathrm{Ma}$, Chattian (late Oligocene), Bernsteinschluff Horizon in the upper part of the Cottbus Formation of the Goitzsche mine, Bitterfeld, Germany.

Calibration: Minimum age of Bazzania.

Emended description: Plants light olive to yellowish brown to reddish brown, shoots up to $5.5 \mathrm{~mm}$ long and up to $0.75 \mathrm{~mm}$ wide; apices occasionally tapering. Irregularly branched, branches ventral-intercalary, similar to main axis or stoloniform (Fig. 4C); stolons $0.1-0.17 \mathrm{~mm}$ wide. Stem somewhat translucent to brown, without hyalodermis, distinctly dorsiventrally applanate, $85-120 \mu \mathrm{m}$ in diameter; cortex of ventral merophyte $4-6$ cells wide, cells rectangular, with equally thickened colorless walls. Rhizoids arising only at the base of underleaves, mostly in \pm loose bundles. Leaves incubous, insertion strongly oblique, straight, length of insertion half the leaf width, imbricate to sometimes remote, planodistichous, often with \pm decurved apex; semiovate to ovate, $100-420 \mu \mathrm{m}$ long $\times 90-310 \mu \mathrm{m}$ wide in the middle, longer than wide, length:width ratio 1.1-1.3:1, leaves on stolons and tapering shoots becoming more distant and smaller (Fig. 4C, D); entire margined; bilobed to ca. $0.2 \times$ the length at apex, on very slender shoots bilobed to 0.3 (Fig. 4D), sinus ca. $45^{\circ}$ or less wide, U-to V-shaped, lobes equal in size, triangular, sometimes \pm claw-like decurved, with very sharp spinous tip, whose terminal cell is longer than wide and often broken off; ventral margin slightly arcuate to almost straight, dorsal one strongly arcuate, especially in basal half, on slender shoots and stoloniform branches more symmetric; with rounded ampliate basal margin extending slightly beyond middle of stem without overlapping leaves of the other side. Cells with colorless, equally thickened walls, without trigones, \pm isodiametric throughout, hexagonal to quadrate to short rectangular, partly seriate, subapically $10-14 \times 10-16 \mu \mathrm{m}$, in basal middle somewhat elongated $(20 \mu \mathrm{m})$. Underleaves free, with transverse, almost straight insertion; reniform, 50-230 $\mu \mathrm{m}$ long $\times 50-230 \mu \mathrm{m}$ wide, wider than long or about as long as wide, length:width ratio $0.8-1: 1,2-3 \times$ wider than stem; on very slender shoots broad elliptic to obovate, about as wide as stem, on stoloniform branches scale-like; base shallowly ampliate and occasionally shortly spurred to cuneate-arcuate, tightly adjacent to stem or obliquely spreading, irregularly quadrilaciniate for $0.3-0.5 \times$ the length, laciniae almost equal in size or the outer somewhat smaller, directed straightly forward, long triangular to lanceolate with very sharp spinous tip; on slender shoots and stolons underleaves irregularly dentate; lateral margin on both sides of underleaves with (1-)2-3(-5) additional spines and teeth of various sizes; terminal cell of laciniae and spines twice or more longer than wide, other cells as those of leaves. Sterile.

Justification: Bazzania polyodus is known from several well-preserved fossils in Baltic as well as Bitterfeld amber. All specimens are sterile, but the vegetative characters allow a reliable assignment to the genus (Grolle \& Meister 2004b). Due to the rareness of fertile specimens in extant Bazzania, the identification relies on gametophytic characters of the lateral leaves and underleaves, like shape, size, number of apical lobes, and presence of marginal teeth, as well as the connateness of the underleaves to the lateral leaves. Another important character is the branching pattern, including the characteristic Bazzania-type branches. The fossil species is characterized by squat, shortly bilobed lateral leaves and irregularly quadrilaciniate underleaves and does not seem to be related to any of the extant species in Europe but rather to representatives of tropical East Asia and Melanesia (Grolle \& Meister 2004b). Grolle \& Meister (2004b) noted that 
fossils of $B$. polyodus lack the diagnostically important stoloniform Bazzania-type branches, but a newly discovered specimen from Baltic amber (GRÖHN 5844) represents a rather extensive shoot system with stolons and allows for an emended description. The specimen (Fig. 4C, D) includes several yellowish to dark red brown gametophyte fragments with the larger fragments in good accordance with type specimen but also with many slender, stoloniform shoots with distant leaves and small, scale-like underleaves. This specimen emends the description of B. polyodus in a particularly important character that might facilitate an assignment to extant taxa.

Bazzania polyodus is well suited as a minimum age constraint for the crown group of Bazzania and was already applied in Heinrichs et al. (2007), Cooper et al. (2012), Feldberg et al. (2014), Laenen et al. (2014), and Sun et al. (2014). In Feldberg et al. (2014) the crown group of Bazzania has an estimated mean age of $60.14 \mathrm{Ma}$, in Laenen et al. (2014) median ages of 34.21-45.99 Ma.

\section{Family: Notoscyphaceae Crand.-Stotl., Váňa \& Stotler}

\section{Genus: Notoscyphus Mitten (1871: 407)}

Extant Notoscyphus currently contains only the paleotropical Notoscyphus lutescens (Lehm. \& Lindenb. in Lehmann 1832: 16) Mitten (1871: 407). The species is characterized by a rather heterogenous morphology and might represent a cryptic species complex (e.g., Wigginton 2004, Váňa \& Long 2009, Braggins et al. 2014, Shaw et al. 2015, Söderström et al. 2016). Two fossil species have been described from Baltic and Bitterfeld amber respectively, namely N. balticus Heinrichs, Schmidt, Schäfer-Verwimp, Gröhn \& Renner (2015c: 40) which provides an age constraint for the genus, and Notoscyphus grollei Váňa, Schäf.-Verw. \& Heinrichs in Váňa et al. (2015a: 153) which is currently not suitable as age constraint because it is known only from Bitterfeld amber whose age is still a matter of discussion.

Notoscyphus grollei is morphologically so similar to $N$. lutescens that it was first described as the extant species by Grolle (1988). It only differs in having distinctly mammillose leaf cells (Váňa et al. 2015a). This species also closely resembles $N$. balticus from Baltic amber but can be distinguished by its larger and mammillose leaf cells and very narrow, colorless rhizoids (Váňa et al. 2015a).

\section{Notoscyphus balticus}

Holotype: GPIH 4565 (Gröhn 5800).

Reference: Heinrichs et al. (2015c), plates I, II.

Age and stratigraphic level: $34-41 \mathrm{Ma}$, Priabonian-Bartonian (Eocene), Baltic region.

Calibration: Minimum age of Notoscyphus.

Justification: Though the assignment is somewhat hampered by the lack of generative structures and branches, $N$. balticus is in good accordance with the description of the genus (Heinrichs et al. 2015c). The most apparent differences between the fossil and extant Notoscyphus are the brown color of the gametophyte, the larger diameter of the rhizoids, and the slightly smaller leaf cells (Heinrichs et al. 2015c). Morphological differences of the underleaves are somewhat ambiguous due to potential damage of the fossil material and the morphological heterogeneity of the extant species.

Currently, the lack of comprehensive molecular data of Notoscyphus hampers a reconstruction of its crown group age and the assignment of the fossil Notoscyphus species. However, the interpretation of the Eocene fossil as a representative of the extant genus Notoscyphus is not conflicting with divergence time estimates. According to Feldberg et al. (2014), who did not use the fossil as a constraint, Notoscyphus originated in the Mesozoic, well before the formation of the Paleogene fossil. It was applied as an age constraint for the genus in Laenen et al. (2014) which resulted in estimated median ages of 35.15-69.04 Ma.

\section{Family: Plagiochilaceae Müll.Frib.}

\section{Genus: Plagiochila (Dumort.) Dumortier (1835: 14)}

\section{Plagiochila groehnii Grolle \& Heinrichs (2003: 289)}

Holotype: GPIH 4309 (Coll. Gröhn 2088b).

References: Grolle \& Heinrichs (2003), figs. 1, 2; Grolle \& Meister (2004b), plate 19e-i.

Age and stratigraphic level: $34-41 \mathrm{Ma}$, Priabonian-Bartonian (Eocene), Baltic region.

Calibration: Minimum age of Plagiochila. 
Justification: Plagiochila groehnii is the only fossil representative of this large subcosmopolitan genus from amber and known only from two shoot fragments. A comparison of $P$. groehnii with extant species is currently hampered by the sterile and very fragmentary state of the fossil and by the taxonomic uncertainties in extant Plagiochila (e.g., Patzak et al. 2016, Renner et al. 2017b, Renner 2018), particularly as the full spectrum of morphological diversity expressed by Plagiochila has not yet been incorporated into the revised framework for infrageneric classification. Plagiochila groehnii closely resembles the flagelliform tapering shoots of the extant P. sciophila Nees ex Lindenberg (1840: 100) from Southeast Asia and southeastern North America, a widely distributed and morphologically heterogenous taxon. The fossil differs from the extant species in having coarser teeth on the leaf margins (Grolle \& Heinrichs 2003). Also, the Neotropical P. subplana Lindenberg (1840: 73) and the African P. integerrima Stephani (1886a: 83) show similarities to the fossil. Long ciliate teeth are characteristic of, but not unique to, many species of Plagiochila sect. Cucullatae Schiffner (1900: 107) to which P. sciophila belongs (Renner 2018).

Plagiochila groehnii shows all relevant characters to be assigned to Plagiochila with high confidence. Therefore, it has already been employed as an age constraint for the genus in several divergence time estimates, e.g., Heinrichs et al. (2007), Cooper et al. (2012), Feldberg et al. (2014), and Laenen et al. (2014). As with Bazzania, capturing data on morphological character expression and distribution across the genus may facilitate more nuanced assignment of the fossil within the Plagiochila crown group.
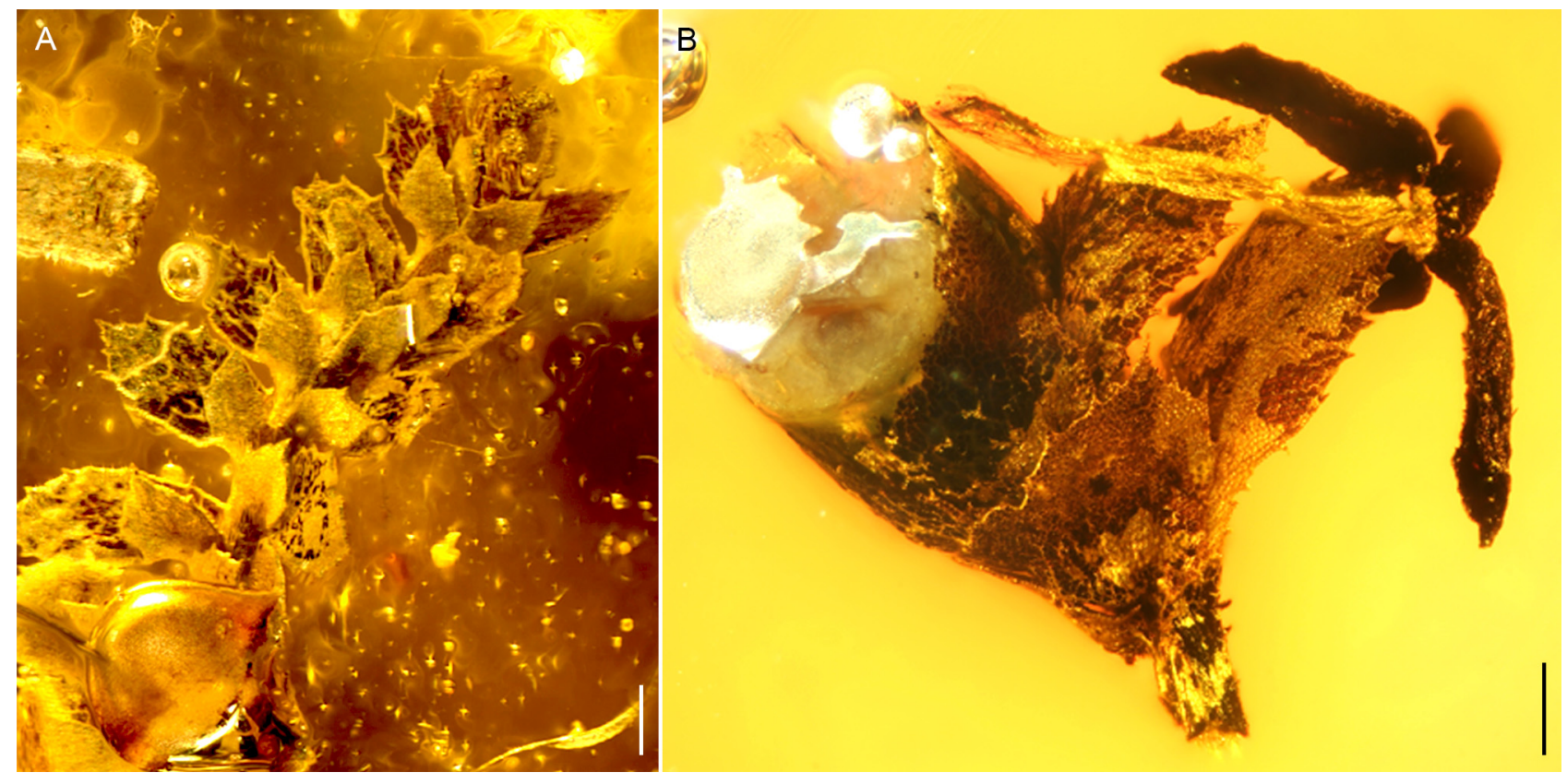

FIGURE 5. Scapaniaceae. A, B. Scapania hoffeinsiana. A. GRÖHN 5824 from Baltic amber in dorsal view. B. MB.Pb.1996/1358a (holotype) from Bitterfeld amber with broken perianth and capsule. Scale bars: A, B=200 $\mu \mathrm{m}$.

Family: Scapaniaceae Mig.

Genus: Scapania (Dumort.) Dumortier (1835: 14)

Scapania hoffeinsiana Grolle in Grolle \& Schmidt (2001: 362); Fig. 5

Holotype: MB.Pb.1996/1358a (Coll. Kutscher), Bitterfeld amber.-Paratypes: MB.Pb.1996/1358b (Coll. Kutscher), Bitterfeld amber; GZG.BST.22057 (Coll. Hoffeins 952a), GZG.BST.22058 (Coll. Hoffeins 952b), Bitterfeld amber.

? = Scapanites acutifolius Gottsche (1886: 122), nom. nud.—Original material: destroyed ("Danziger Museum”, coll. Menge 25).—Cf. Grolle \& Meister 2004b.

Additional specimens: Baltic amber: GRÖHN 5824. Bitterfeld amber: GZG.BST.22059 (Coll. Hoffeins 1512-2).

References: Grolle \& Schmidt (2001), figs. 1-10; Grolle \& Meister (2004b), plate 23a-e; Frahm \& Gröhn (2013), figs. 7, 8; Heinrichs et al. (2018a), plate II(3, 4).

Age and stratigraphic level: 34-41 Ma, Priabonian-Bartonian (Eocene), Baltic region; and $24 \mathrm{Ma}$, Chattian (late Oligocene), Bernsteinschluff Horizon in the upper part of the Cottbus Formation of the Goitzsche mine, Bitterfeld, Germany.

Calibration: Minimum age of Scapania. 
Justification: Scapania has a mainly Laurasian distribution and includes 102 accepted extant species (e.g., Söderström \& Séneca 2006, Söderström et al. 2016, Heinrichs et al. 2012a, Potemkin \& Müller 2020). Scapania hoffeinsiana is the only fossil species known from this genus and one of the rarer cases preserved with perianth and capsule (Grolle \& Schmidt 2001, Grolle \& Meister 2004b). The complicate bilobed leaves (Fig. 6A) with a smaller dorsal lobe which is folded against the ventral one forming a keel and the lack of a vitta are in good accordance with the morphological description of the genus (e.g., Paton 1999, Schuster 2002, Potemkin \& Müller 2020). Though the perianth has been damaged and only the lower part is preserved, the remains of the gynoecium and the sporophyte support the generic assignment of the holotype (Fig. 6B). The paratypes and the additional specimens are sterile but allow a detailed study of vegetative characters (Grolle \& Meister 2004b, Frahm \& Gröhn 2013). A comparison with extant species is currently difficult. Despite molecular phylogenetic analyses (Heinrichs et al. 2012a, Mamontov et al. 2018b) and morphological revisions (e.g., Choi et al. 2012, Potemkin \& Müller 2020) the taxonomy of extant Scapania is still subject to controversy and many species remain insufficiently known.

Grolle \& Schmidt (2001) have compared the fossil to Douinia ovata (Dickson 1793: 11) Buch (1928: 14) which differs by its subentire leaf lobes and strongly plicate perianth, and with $S$. stephanii Müller (1905: 273) [(now $S$. ligulata Stephani (1904: 14) subsp. stephanii (Müll.Frib.) Potemkin, Piippo \& Koponen (2004: 423)] from Japan which differs by its broader lobes of stem and involucral leaves and slightly winged keel. The fossil shows strong morphological affinities to extant subgen. Scapania (Feldberg et al. 2014) and might belong to sect. Apiculatae Buch (1928: 53). It resembles the European-North American S. umbrosa (Schrader 1797: 5) Dumortier (1835: 14) which differs by the broader lobes of stem and involucral leaves with less coarse dentation and by a somewhat winged, longer keel. Because of the reliable generic placement, S. hoffeinsiana has been employed as age constraint in Feldberg et al. (2013, 2014) and Laenen et al. (2014).

\section{Family: Solenostomataceae Stotler \& Crand.-Stotl.}

\section{Genus: Solenostoma Mitten (1864b: 51)}

Solenostoma berendtii (Grolle) Váňa, Schäf.-Verw. \& Heinrichs in Váňa et al. (2015b: 287)

Basionym: Jungermannia berendtii Grolle (1980b: 401).--Holotype: MB.Pb.1979/477 (Coll. Berendt).

References: Grolle (1980b), Abb. 1a-c, Tafeln XXX, XXXI as Jungermannia berendtii; Grolle \& Meister (2004b), plate 12h-i as Jungermannia berendtii; Váňa et al. (2015b), figs. 1-3; Heinrichs et al. (2018a), plate I(4).

Age and stratigraphic level: 34-41 Ma, Priabonian-Bartonian (Eocene), Baltic region.

Calibration: Minimum age of Solenostoma.

Justification: This fossil is only known from the sterile type specimen and has been placed in Jungermannia Linnaeus (1753: 1131) subgen. Solenostoma (Mitt.) Amakawa (1960: 53) by Grolle (1980b). Recently, the genus Solenostoma was reinstated based on molecular phylogenetic evidence (Hentschel et al. 2007, Shaw et al. 2015) and the fossil was therefore transferred to Solenostoma (Váňa et al. 2015b).

The fossil resembles the Asiatic S. truncatum (Nees 1830: 29) R.M.Schust. ex Váňa \& Long (2009: 509) of subgen. Plectocolea Mitten (1864a: 156) in having numerous long rhizoids, distinct trigones, and subquadrate-rotund to elongate-elliptical leaves, but the lack of fertile structures and the scarce fossil material make a detailed assessment of the relationships currently impossible. The relatively reliable generic assignment provides a minimum age for the genus Solenostoma. It has been employed as age constraint by Laenen et al. (2014) for Jungermannia s.1.

\section{Order: Porellales Schljakov}

\section{Family: Frullaniaceae Lorch}

Frullaniaceae represent a lineage of mainly epiphytic leafy liverworts within the Porellales and one of the most species rich taxa found as amber inclusions (Grolle \& Meister 2004b, Hentschel et al. 2009a, Heinrichs \& Schmidt 2010, Heinrichs et al. 2011b, 2012b, c, 2017a, b, 2018a, Konstantinova et al. 2012, Mamontov et al. 2015a, 2017, 2018a, 2019, 2020a, Feldberg et al. 2018, 2021, Li et al. 2020, 2021). Approximately 15 species from different amber deposits have already been described, dating from the mid-Cretaceous to the Miocene. The family includes two to four genera: the extant Frullania, the extinct Protofrullania Heinrichs (2017a: 225), and probably also the extinct genera Kaolakia Heinrichs, M.E.Reiner, K.Feldberg, von Konrat \& A.R.Schmidt in Heinrichs et al. (2011b: 236) as well as 
Pseudofrullania Heinrichs, K.Feldberg, M.A.M.Renner \& Schäf.-Verw. in Heinrichs et al. (2018a: 225), though the familial assignment of the latter two is not entirely certain (Heinrichs et al. 2011b, 2018a, Feldberg et al. 2021) and they can consequently not be employed as age constraints.

Fossil Frullaniaceae represent two major groups, namely the Cretaceous representatives which often differ significantly from extant taxa, and the Cenozoic ones which are generally more similar to the extant diversity. The number of Cretaceous Frullaniaceae fossils is relatively low. However, their peculiar morphologies indicate a turnover within the family during this period (e.g., Heinrichs et al. 2018a).

This group contains several interesting morphotypes which might not be closely related to one another or to Cenozoic species. One of these types is Kaolakia borealis Heinrichs, M.E.Reiner, K.Feldberg, von Konrat \& A.R.Schmidt in Heinrichs et al. (2011b: 236) from mid-Cretaceous Alaskan amber. The most notable character of this taxon is the presence of two saccate ventral segments per leaf, a character which is rarely expressed in extant Frullaniaceae (von Konrat \& Braggins 2001, Heinrichs et al. 2011b, Feldberg et al. 2021). The majority of extant and fossil Frullaniaceae possess leaves with strongly unequal lobes, of which the dorsal lobe is always explanate (laminar) and reniform or cordate, the ventral, smaller lobule is mostly saccate with a posterior opening (Frullania-type lobule) or occasionally explanate, and the third is represented by a more or less small, filiform to triangular stylus situated between the lobule and the stem (e.g., Schuster 1992). Two saccate structures per leaf are occasionally formed on the first leaf of a branch (von Konrat \& Braggins 2001), and the two saccate structures on every leaf of Kaolakia might represent an extreme version of this tendency. In general, the leaf characters in Kaolakia as well as the shape of beaked perianth are characteristic of Frullaniaceae, therefore this genus might represent a separate, specialized lineage of the family.

Another type of Cretaceous Frullaniaceae is represented by Protofrullania cornigera Heinrichs (2017a: 225) described from mid-Cretaceous Kachin amber (Myanmar). In the description of Protofrullania, Heinrichs et al. (2017a) noted that the fossil resembles Frullania in its general habit, color, and leaf shape, and also recently described male and female fossils (Feldberg et al. 2021) support the assignment to Frullaniaceae. The differentiating features of Protofrullania are the strap-shaped, ciliate underleaves and the development of rhizoids in the upper portion of these underleaves.

\section{Genus: Frullania}

The only extant genus of Frullaniaceae is Frullania which is morphologically well circumscribed, yet has a very complex subgeneric taxonomy (e.g., Hentschel et al. 2009b, 2015, Heinrichs et al. 2010, Ramaiya et al. 2010, von Konrat et al. 2010, 2012, 2013, Carter et al. 2017, Mamontov et al. 2020b). The genus has a subcosmopolitan distribution with most species occurring in humid tropical regions but also as xerophytes and in temperate as well as arctic and alpine areas (Schuster 1992, Hentschel et al. 2009b).

Three fossil species of Frullania occur in mid-Cretaceous Kachin amber from Myanmar and provide a minimum age for the genus (Fig. 6 A-C). Most Cenozoic fossils of Frullania are found in Paleogene Baltic, Bitterfeld, and Rovno ambers, while only one fossil from Miocene Dominican amber was described to date. The morphological features of all these species, including the shape and reciprocal proportions of leaf lobes and lobules, underleaves, bracts and bracteoles, and also perianths, are characteristic of extant Frullania, so all these fossils can be considered part of the crown group. However, the assignment to subgenera and sections is not easy. Research concerning the taxonomy of Frullania has rapidly progressed in recent years, but definite morphological distinctions between lineages can be difficult (von Konrat et al. 2006, 2010, 2011, 2013, Hentschel et al. 2015, Carter et al. 2017).

Recently some important nomenclatural changes were made for the genus Frullania which necessitated changes of the subgeneric classification (Lima et al. 2020). Frullania tamarisci (Linnaeus 1753: 1134) Dumortier (1835: 13) is again considered the lectotype of the genus (Stotler \& Crandall-Stotler 2017). Since F. tamarisci belongs to subgen. Thyopsiella Spruce (1884: 41) this subgenus becomes subgen. Frullania whereas subgen. Frullania fide Hentschel et al. (2015) and Söderström et al. (2016) becomes subgen. Trachycolea.

Many taxa found in European Baltic, Bitterfeld, and Rovno amber show close morphological affinities to representatives from the Southern Hemisphere or belong to genera which are restricted to this area today (Grolle 1988, Mamontov et al. 2015b, Heinrichs et al. 2015c). Therefore, it is interesting that representatives resembling extant lineages of Frullania with a main distribution in the Southern Hemisphere, especially subgen. Chonanthelia Spruce (1884: 8), subgen. Homotropantha Spruce (1884: 35), and subgen. Meteoriopsis Spruce (1884: 37), have not yet been found among the Cenozoic species. Moreover, there are no species that would undoubtedly be considered to belong to subgen. Microfrullania (Schuster 1970: 280) Schuster (1992: 34) in the present sense (Carter et al. 2017). Grolle \& Meister (2004b) assigned F. varians Caspary (1887: 5), which occurs in Baltic, Bitterfeld, and Rovno amber, to 
this subgenus. The autoecious species is by far the most frequent inclusion with far over 60 fossils (Konstantinova et al. 2012) and is known with androecia, gynoecia with perianth (Fig. 6D), and sporophyte (Fig. 6E). The complete preservation might render it suitable as age constraint, but due to its heterogeneous morphology it needs a thorough revision before the affinities to the extant diversity can be assessed with confidence. Frullania varians might represent a complex of closely related species as in extant Frullania, where species complexes and semi-cryptic to cryptic species are common (e.g., Heinrichs et al. 2010, Mamontov et al. 2015a, Carter et al. 2017).

Most fossil Frullania species resemble the extant subgenera Diastaloba Spruce (1884: 55) s.1., Frullania, and Trachycolea, which are the groups with a mostly northern (Laurasian) or worldwide distribution. However, the combinations of character states are unusual in several Eocene and Oligocene representatives, so an affiliation of these species to any extant subgenera is challenging and few species can be assigned with confidence.

Currently the assignment of species with morphological affinities to Diastaloba s.l. is very problematic even if copious and well-preserved material is at hand. Extant representatives occur in tropical America, Asia, and Oceania and have been resolved as polyphyletic in molecular phylogenetic and morphological studies (Hentschel et al. 2009b, 2015, Söderström et al. 2016, Silva et al. 2017, Winter \& Schäfer-Verwimp 2020). Typical characters, e.g., lobules inserted remotely from the stem, also occur in subgenera Microfrullania and Mammillosae Hattori (1986: 226), whereas the latter has not been investigated by molecular methods yet. Frullania baltica Grolle (1985b: 89), which is preserved with androecia, gynoecia, and sporophyte (Grolle 1998; Fig. 6F), and F. schmalhausenii Mamontov, Ignatov \& Perkovsky (2019: 1100), which is only known from the sterile holotype, are both very similar to the extant Neotropical F. obcordata (Lehm. \& Lindenb. in Lehmann 1834: 51) Lehm. \& Lindenb. in Gottsche et al. (1845b: 447) (Mamontov et al. 2019), a species belonging to the lineage Diastaloba IV in the molecular phylogenetic analyses by Hentschel et al. (2009b), respectively to the recently established subgenus Caulisequa Winter \& Schäfer-Verwimp (2020: 14). An additional fossil with a Diastaloba-like morphology has been described from Miocene Dominican amber, but due to the incomplete preservation only to subgenus level (Heinrichs \& Schmidt 2010). A thorough revision based on extended datasets and thorough morphological studies is needed to obtain a sufficient characterization of the lineages and a reliable assignment of the Diastaloba-like fossils, but preliminary studies indicate that morphological definitions are possible (Hentschel et al. 2015).

Several other fossils are difficult to assign because they display characters not seen in extant Frullania. One group is represented by F. acutata Caspary (1887: 5) emended Grolle (1981a: 144) from Baltic amber, F. ekaterinae Mamontov, Ignatov \& Perkovsky (2019: 1096) from Rovno amber, F. pycnoclada Grolle (2004b: 25) from Baltic as well as Rovno amber, and F. vanae Mamontov, Atwood, Perkovsky \& Ignatov (2020a: 424) from Rovno amber. The isolated characters, including acute to obtuse leaf lobe apices in F. acutata and F. ekaterinae, dimorphic underleaves (different stem and branch ones) in F. acutata and F. pycnoclada, as well as the shape of leaf lobules are typical for subgen. Frullania. However, the front surface of lobules in these species (in F. vanae only the ones on branches) bears two rows of opposite mammillae, a morphological character unknown of extant subgen. Frullania. These species might be related to one another and represent an extinct subgenus or section (Mamontov et al. 2020a).

\section{Frullania subgenus: incertae sedis}

Frullania baerlocheri Heinrichs, M.E.Reiner, K.Feldberg, von Konrat, Hentschel, Váňa \& A.R.Schmidt in Heinrichs et al. (2012b: 26); Fig. 6A

Holotype: AMNH Bu-FB $1 \mathrm{~g}$.

= Frullania pinnata Heinrichs, K.Feldberg, Schäf.-Verw. \& Krings in Heinrichs et al. (2017b: 57).—Holotype: GZG.BST.21963.—Syn. fide Li et al. (2021).

Additional specimens: PB23288; GZG.BST.22015 (Coll. Müller BuB3538); MÜLLER BuB3681, BuB3682; SNSBBSPG 2021 XII 1 (Coll. Müller BuB1874; syninclusion Protofrullania cornigera).

References: Heinrichs et al. (2012b), plate IV, fig. 2; Heinrichs et al. (2017b), figs. 1-3; Heinrichs et al. (2018a), plate IV(7); Li et al. (2021), figs. 1-3; Feldberg et al. (2021), figs. 1D, E, 2A, B, 3.

\section{Frullania cretacea Hentschel, Schmidt \& Heinrichs (2009a: 326); Fig. 6B}

Holotype: AMNH B-011.

Additional specimens: AMNH Bu-FB 1 a-f, Bu-FB 51; GZG.BST.22016 (Coll. Müller BuB3533), GZG.BST.22017 (Coll. Müller BuB1190); MÜLLER BuB1772, BuB3530; WUNDERLICH F3157/BU/CJW.

References: Hentschel et al. (2009a), figs. 1-10; Heinrichs et al. (2012b), plates I, II, fig. 1; Heinrichs et al. (2018a), plate IV(4); Feldberg et al. (2021), figs. 1F, 2C, 4A, B. 

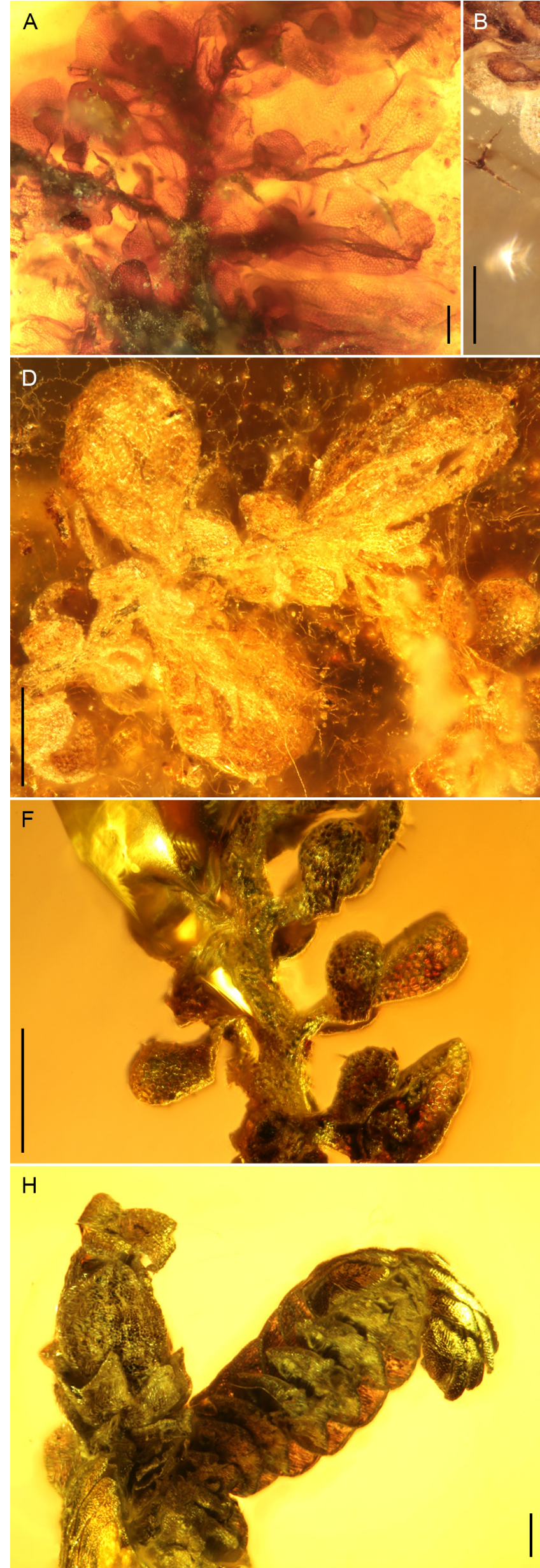
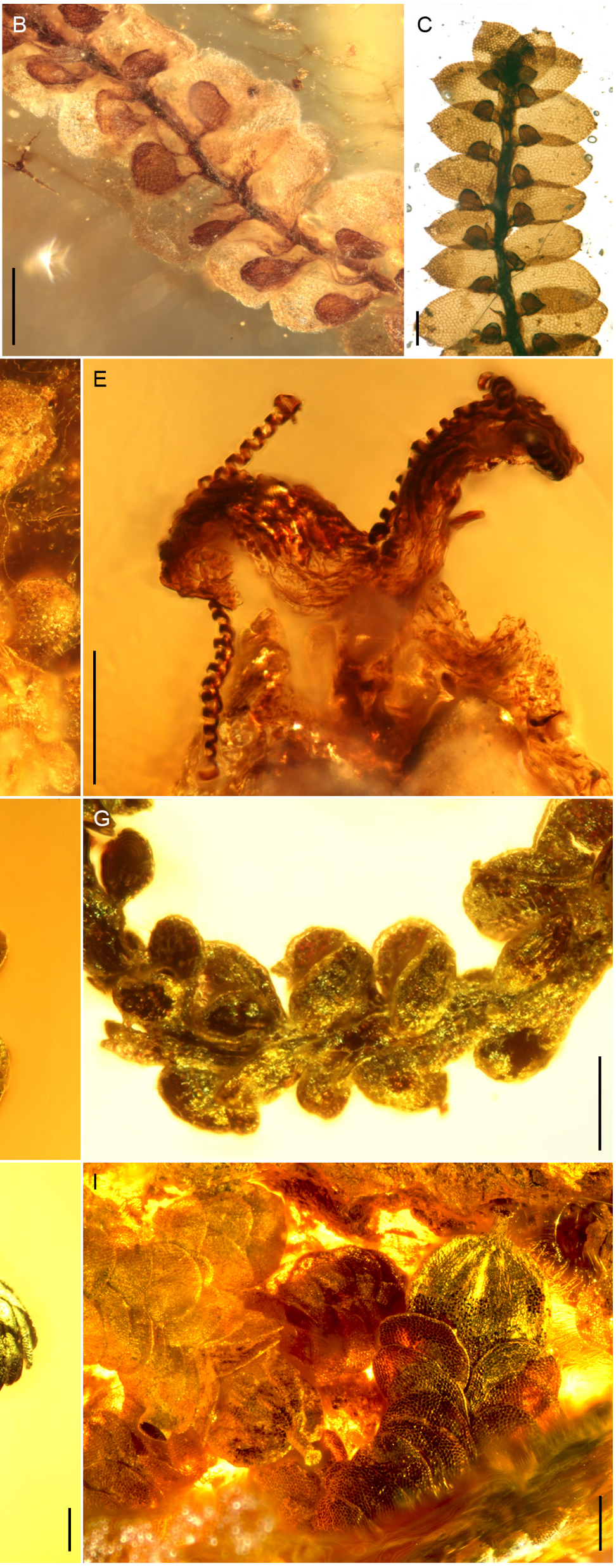
FIGURE 6. Frullania. A. Frullania baerlocheri, GZG.BST.22015 from Burmese amber in ventral view with rounded (holostipous) underleaves. B. Frullania cretacea, GZG.BST.22016 from Burmese amber in ventral view with ciliate underleaves. C. Frullania partita, PB23146 (holotype) in ventral view with bifid underleaves. D, E. Examples of fertile structures in fossil Frullania. D. Frullania varians, GZG.BST.22045 from Bitterfeld amber in ventral view with two androecia and one terminal gynoecium with perianth. E. Frullania varians, GZG.BST.22046 from Bitterfeld amber with capsule and elaters. F. Frullania baltica, GZG.BST.22047 from Bitterfeld amber in ventral view. G. Frullania casparyi, GZG.BST.22060 from Bitterfeld amber in ventral view. H, I. Frullania schumannii. H. GRÖHN 2058 from Baltic amber in ventral view with perianth and capsule. I. GZG.BST.22063 from Bitterfeld amber with two beaked perianths. Scale bars: A-D, F, H=200 $\mu \mathrm{m}, \mathrm{E}, \mathrm{G}=100 \mu \mathrm{m}, \mathrm{I}=500 \mu \mathrm{m}$.

\section{Frullania partita Li, Wang, Schneider \& Wu (2020: 104341 [2]); Fig. 6C} Holotype: PB23146.

References: Li et al. (2020), figs. 1, 2; Feldberg et al. (2021), figs. 1G, 2D, 4C, D.

Age and stratigraphic level: Frullania baerlocheri, F. cretacea, and F. partita derive from 99 Ma, late Albian-early Cenomanian (Late Cretaceous) amber mined southwest of the village of Tanai ca. 105 km north of Myitkyina in Kachin State, northern Myanmar (Burmese amber).

Calibration: Frullania baerlocheri, F. cretacea, and F. partita provide the minimum age of Frullania.

Justification: Frullania baerlocheri (Fig. 6A), F. cretacea (Fig. 6B), and F. partita (Fig. 6C) can confidently be assigned to the extant genus Frullania (Heinrichs et al. 2018a, Feldberg et al. 2021, Li et al. 2020, 2021). However, the combinations of morphological characters these species display are unknown in extant crown group lineages and they might thus represent stem or extinct crown group lineages. Of the three species, F. partita is most similar to extant crown group representatives of the genus. The remotely inserted lobules are reminiscent of the polyphyletic and largely unrevised extant subgen. Diastaloba s.1. (Hentschel et al. 2009b, 2015). A somewhat similar extant species is F. apiculata (Reinwardt, Blume \& Nees 1824: 222) Nees in Gottsche et al. (1845b: 452) from tropical Asia, albeit the lobules are more elongated and the underleaves broader.

The reliable generic assignment of Cretaceous Frullania already provided age constraints for the Frullania crown group. Based on this constraint Feldberg et al. (2014) estimated a mean age of 107.9 Ma, Laenen et al. (2014) median ages of 123.67-174.7 Ma, and Silva et al. (2017) a mean age of 166.75 Ma for Frullania.

\section{Frullania subgenus: Frullania (fide Lima et al. 2020)}

Fossils resembling this subgenus are rather common, but except for F. casparyi Grolle (1985b: 92) and F. riclefgrollei Mamontov, Heinrichs, Schäfer-Verwimp, Ignatov \& Perkovsky (2015a: 32), which might provide a minimum age for this subgenus, not many can be assigned with high confidence. Another species which has been assigned to this subgenus but shows unusual characters is F. mammilligera Grolle (2003: 155) from Bitterfeld amber (Grolle \& Meister, 2004b). This species is known only from the fertile holotype and has ocelli, but the strongly mammillose lobule surface is unique within the subgenus. The unclear assignment to the extant diversity as well as the restriction to Bitterfeld amber, whose age is still debated, render it currently unsuitable as age constraint.

Also F. truncata Caspary (1887: 4) and F. zerovii Mamontov, Ignatov \& Perkovsky (2018a: 104) might belong to subgen. Frullania. These species resemble one another in having rounded leaf lobes, leaf lobules with a smooth surface, equal semicircular mouth margins, a constriction above the lobule mouth, and the widest part in the upper half. The species differ mainly by the shape of underleaves. The leaves and underleaves are most similar to those in extant F. chilcootiensis Stephani (1886b: 98) [sin. F. hattoriana Godfrey \& Godfrey (1980: 321)] of subgen. Frullania (Mamontov et al. 2020b, Atwood \& Mamontov 2020). These fossils can potentially be considered to belong to sect. Frullania though none of them has ocelli. However, as follows from Hentschel et al. (2009b) and Mamontov et al. (2020b), an absence of ocelli could not exclude an affiliation of any species to subgen. Frullania, although its presence remains an important feature in the case of fossils, until an independent origin of ocelli in different lineages of Frullania is found. 


\section{Frullania casparyi; Fig. 6G}

Holotype: WAR-MZ 17449 (Coll. Giecewicz), Baltic amber.

? = Frullania tenella Caspary (1887: 5), nom. illeg. [non Sande Lac. 1855].-Type: destroyed.—Cf. Grolle (1985b: 92).

Additional specimens: Baltic amber: GRÖHN 5841; MB.Pb.1979/481 (Coll. Thomas); WAR-MZ 469/16 (Coll. Rieband); VELTEN H0001b. Bitterfeld amber: GZG.BST.22060 (Coll. Grabenhorst Le-44), GZG.BST.22061 (Coll. Hoffeins 5-22), GZG.BST.22062 (Coll. Hoffeins 5-41); MB.Pb.1992/19 (Coll. Kutscher H003), MB.Pb.1992/20 (Coll. Kutscher H019), MB.Pb.1992/21 (Coll. Kutscher H016), MB.Pb.1997/31 (Coll. Grolle M-12/2), MB.Pb.1997/43 (Coll. Grolle M-14/4), MB.Pb.1997/7 (Coll. Grolle 87/F4a + b).

References: Grolle (1985b), plate III, fig. 2e-i; Kosmowska-Ceranowicz (2001), phot. 2; Grolle \& Meister (2004b), plate $6 \mathrm{a}-\mathrm{e}$.

Age and stratigraphic level: $34-41 \mathrm{Ma}$, Priabonian-Bartonian (Eocene), Baltic region; and $24 \mathrm{Ma}$, Chattian (late Oligocene), Bernsteinschluff Horizon in the upper part of the Cottbus Formation of the Goitzsche mine, Bitterfeld, Germany.

\section{Frullania riclefgrollei}

Holotype: SIZK-K-2012.

Reference: Mamontov et al. (2015a), plates I, II.

Age and stratigraphic level: 35-37 Ma, Priabonian (late Eocene), amber quarry "Pugach", Klesov, Ukraine (Rovno amber).

Calibration: Frullania casparyi and F. riclefgrollei provide a minimum age for Frullania subgen. Frullania; possibly sect. Microphyllae (Schuster 1985: 370) Gradst., Ilk.-Borg. \& E.Lima in Lima et al. (2020: 122).

Justification: Frullania casparyi and F. riclefgrollei are morphologically quite similar but differ in some important characters (Mamontov et al. 2015a). Frullania casparyi (Fig. 6G) is much smaller than F. riclefgrollei, its underleaves are less deeply bifid and have lobes with a 1-3 cells rather than 1 cell long uniseriate apex, and the ocelli form a moniliate row consisting of 2-5 cells rather than a 1-2 cells wide row of 12-18 ocelli. The rows of ocelli of both species are larger and more refractive than the surrounding cells, as is typical for subgen. Frullania (Grolle 1985b, Grolle \& Meister 2004b, Hentschel et al. 2009b, Mamontov et al. 2015a, Lima et al. 2020). While F. casparyi is a dioecious species preserved with androecia as well as gynoecia, F. riclefgrollei is known only in sterile condition. Both species seem to be closely related to the European species F. microphylla (Gottsche in Rabenhorst 1862: 109 [209]) Pearson (1894: 328) of subgen. Frullania sect. Microphyllae which also has caducous leaves, rounded leaf apices, an oblique lobule insertion, deeply bifid underleaves, and 1-2(3) cells wide rows of ocelli (Paton 1999, Grolle \& Meister 2004b, Mamontov 2015a, Lima et al. 2020). However, this species is much smaller and has leaf cell walls without distinct trigones. Subgen. Frullania is further characterized by spreading, semi-cordate leaves with one auricle at the leaf base, narrow clavate to cylindrical lobules, and a smooth, keeled perianth (Hentschel et al. 2009b, Lima et al. 2020). Morphologically also rather similar is the largely tropical subgen. Meteoriopsis which is differentiated by absence of ocelli (Hentschel et al. 2009b, Mamontov et al. 2017). The fossils can provide a minimum age constraint for subgen. Frullania and possibly even sect. Microphyllae.

\section{Frullania subgenus: Trachycolea (fide Lima et al. 2020)}

Frullania subgen. Trachycolea is morphologically diverse and forms a robust lineage which is well separated from the remainder of the genus (Hentschel et al. 2009b). Two fossils are known from European ambers. Frullania rovnoi Mamontov, Hentschel, Konstantinova, Perkovsky \& Ignatov (2017: 337) and F. schumannii (Caspary 1887: 3) Grolle (1981b: 102) can be assigned with some confidence and might provide a minimum age for the subgenus or even the Southern Hemispheric sect. Australes Verdoorn (1930: 58) as is discussed below.

Another species with close morphological affinities to this section is F. grabenhorstii Heinrichs, K.Feldberg, Alina S.Müll., Schäf.-Verw., von Konrat \& A.R.Schmidt in Feldberg et al. (2018: 94), but it is known only from Bitterfeld amber and therefore currently not suitable as age constraint. Also, F. zerovii shows strong affinities to this section through some characters of the leaf lobes and lobules (Mamontov et al. 2018a). 


\section{Frullania rovnoi}

Holotype: SIZK-K-10049F.

Reference: Mamontov et al. (2017), figs. 1, 2.

Age and stratigraphic level: 35-37 Ma, Priabonian (late Eocene), amber quarry "Pugach", Klesov, Ukraine (Rovno amber).

\section{Frullania schumannii; Fig. 6H, I}

Basionym: Lejeunea schumannii Casp.-Neotype: MB.Pb.1979/692 (Coll. Künow 149), Baltic amber; designated by Grolle (1985b).— Holotype: destroyed (“Altstädtisches Gymnasium of the former Königsberg”, 1868, coll. V. Duisburg).—Cf. Grolle 1981b, 1985b, Grolle \& Meister 2004b.

= Frullania scyphoides Mägdefrau (1957: 434).--Holotype: SNSB-BSPG 1967 XX 2 (Coll. Scheele), Baltic amber.--Syn. fide Grolle (1981b).

Additional specimens: Baltic amber: GRÖHN 2013, 2026, 2057, 2058, 2059, 2090; LIEDTKE B650 P4; WAR-MZ 2172/1, 20102); VELTEN H1001. Bitterfeld amber: GRÖHN 379; GZG.BST.22063 (Coll. Grabenhorst Le-68), GZG.BST.22064 (Coll. Hoffeins 622-1); MB.Pb.1996/1350a (Coll. Striebich), MB.Pb.1996/1350b (Coll. Striebich), MB.Pb.1996/1353 (Coll. Kutscher), MB.Pb.1997/10, MB.Pb.sn (Coll. Kutscher Ku-98H02b).

References: Caspary (1887), Tafel I Bild 10 as Lejeunea schumannii; Caspary \& Klebs (1907), Tafel III Bilder 20, 20a, b, 21 as Lejeunea schumannii; Mägdefrau (1957), Tafel XII Figs. 2-4 as Frullania scyphoides; Grolle (1981b), figs. 1-5; Grolle (1985b), plate IV, fig. 3; Weitschat \& Wichard (2002), plate 2a, c; Grolle \& Meister (2004b), plates 10d-g, 11; Feldberg et al. (2018), fig. 3D-F; Heinrichs et al. (2018a), plate IV(2).

Age and stratigraphic level: $34-41 \mathrm{Ma}$, Priabonian-Bartonian (Eocene), Baltic region; and $24 \mathrm{Ma}$, Chattian (late Oligocene), Bernsteinschluff Horizon in the upper part of the Cottbus Formation of the Goitzsche mine, Bitterfeld, Germany.

Calibration: Frullania rovnoi and F. schumannii provide a minimum age for Frullania subgen. Trachycolea; possibly sect. Australes.

Justification: Frullania subgen. Trachycolea sect. Australes is mainly distributed in Eastern Asia and Australasia and is well characterized by leaf cells with distinct trigones, large campanulate leaf lobules with a constricted mouth inserted close to the stem, nearly flat underleaves, and 4-plicate smooth perianths (Grolle 1981b, Hentschel et al. 2015 , Mamontov et al. 2017). In molecular phylogenies, the section forms a robust subclade within a largely polytomous subgen. Trachycolea (Hentschel et al. 2009b as subgen. Frullania). Both fossils are in good accordance with the morphological definition of sect. Australes and can be differentiated by underleaf characters. The underleaves of $F$. rovnoi are widest in the middle and bear several lateral teeth or angular projections, whereas those of $F$. schumannii are widest above the middle and ornamented with only 1-2 rounded, rarely tooth-like lateral projections (Mamontov et al. 2017). Only a couple of the extant species, e.g., F. dentata Hattori (1974: 231) from Papua New Guinea, have roughly and irregularly dentate-angulate underleaf margins like those of $F$. rovnoi. While in $F$. rovnoi there has been found only one juvenile perianth, the autoecious F. schumannii is known to have androecia on short side branches as well as terminal gynoecia with smooth 4-plicate perianths (Fig. 6H, I). In combination with a thorough morphological investigation of extant species and molecular phylogenetic datasets the species could provide a minimum age for the section.

Silva et al. (2017) estimated a mean age of $24.40 \mathrm{Ma}$ for the crown group of subgen. Trachycolea (as subgen. Frullania), but the appearance of fossils with the typical morphology of this subgenus as well as sect. Australes already in the Eocene indicates that the radiation of subgen. Trachycolea might have started much earlier. A thorough crossvalidation comparing age estimates obtained by different age constraints could elucidate the diversification of this large subgenus (e.g., Feldberg et al. 2013, Bechteler et al. 2017b).

Family: Jubulaceae H.Klinggr.

Genus: Nipponolejeunea Hattori (1944: 124)

Nipponolejeunea europaea Grolle (1981a: 146)

Holotype: MB.Pb.1979/471-E (Coll. Künow), Baltic amber (syninclusions Cheilolejeunea latiloba (Caspary 1887: 3) Grolle (1984c: 230) 471-B, G, H; Frullania acutata 471-C; Radula sphaerocarpoides Grolle (1980b: 404) 471-A).

Additional specimens: Baltic amber: GRÖHN 2014, 2035, 2052b, 2053; GZG.BST.22065 (Coll. Hoffeins 1151), 
GZG.BST.22066 (Coll. Hoffeins 1499/7); MB.Pb.1979/471-D (Coll. Künow), MB.Pb.1979/471-F (Coll. Künow), MB.Pb.1979/480 (Coll. Thomas). Bitterfeld amber: GZG.BST.22067 (Coll. Grabenhorst Le-3); LUDWIG Bi2014; MB.Pb.1996/1352 (Coll. Gröhn 0366a), MB.Pb.sn (Coll. Kutscher Ku-98H16a).

References: Caspary (1887), Tafel I Bild 24 as Frullania acutata; Grolle (1981a), Abb. 3, Tafeln 3-6; Grolle \& Meister (2004b), plates 17, 18 as the extant Nipponolejeunea subalpina (Horikawa 1939: 360) Hattori (1944: 125); Heinrichs et al. (2018a), plate III $(1,2)$.

Age and stratigraphic levels: 34-41 Ma, Priabonian-Bartonian (Eocene), Baltic region; and $24 \mathrm{Ma}$, Chattian (late Oligocene), Bernsteinschluff Horizon in the upper part of the Cottbus Formation of the Goitzsche mine, Bitterfeld, Germany.

Calibration: Minimum age of Nipponolejeunea.

Justification: Nipponolejeunea is a morphologically and molecularly strongly isolated genus of Jubulaceae with two extant species in Northeastern Asia (Grolle 1981a, Ahonen 2006, Söderström et al. 2016). Nipponolejeunea europaea is so similar to $N$. subalpina that the fossil has been transferred to the extant species by Grolle \& Meister (2004b). However, molecular phylogenetic analyses showed that DNA-sequences of the extant species are very similar and that the split between them occurred in the Miocene (Heinrichs et al. 2007). Therefore, the fossil probably represents an extinct species. Nipponolejeunea europaea is a suitable constraint for the genus and it has already been employed in Heinrichs et al. (2007), Wilson et al. (2007), and Cooper et al. (2012) for Jubulaceae. Feldberg et al. (2014) and Sun et al. (2014) assigned it to the stem of Nipponolejeunea, which resulted in mean ages of 74.3 Ma respective 84.82 Ma. Laenen et al. (2014) assigned it to Nipponolejeunea with resulting median ages of 34.22-46.8 Ma.

\section{Family: Lepidolaenaceae Nakai}

\section{Genus: Gackstroemia Trevisan (1877: 397)}

\section{Gackstroemia cretacea Heinrichs, Schäfer-Verwimp, Feldberg \& Schmidt (2014b: 49)}

Holotype: AMNH BU ASJH-1.

References: Heinrichs et al. (2014b), plate I, fig. 1; Heinrichs et al. (2018a), plate III(4); Feldberg et al. (2021), fig. $1 \mathrm{~A}$.

Age and stratigraphic level: $99 \mathrm{Ma}$, late Albian-early Cenomanian (Late Cretaceous), amber mines southwest of the village of Tanai ca. $105 \mathrm{~km}$ north of Myitkyina in Kachin State, northern Myanmar (Burmese amber).

Calibration: Minimum age of Gackstroemia.

Justification: The family is characterized by incubous foliation and complicate bilobed lateral leaves with a large dorsal lobe and saccate, helmet-shaped, Frullania-type lobules (e.g., Crandall-Stotler et al. 2009, Heinrichs et al. 2014b). Contrary to Frullaniaceae, these saccate lobules are formed on the lateral leaves and also on the underleaves.

Gackstroemia cretacea can be clearly identified has a member of the genus by the incubous leaves with large, dorsal lobes that bear one apical cilium and ventral saccate Frullania-type lobules with apical cilia. Also, the underleaves are converted into pairs of saccate, Frullania-type lobules on the upper part of the shoot and only the underleaf at the base of the shoot is a laminar and bifid. It is possible that the amber inclusion represents a terminal branch fragment, what is indicated by the development of the underleaves and the complete lack of branches (Heinrichs et al. 2014b). The interpretation of the fossil as a member of Gackstroemia is also supported by divergence times estimates. Cooper et al. (2012) reconstructed the split between Gackstroemia and Lepidolaena Dumortier (1835: 13) in the Cretaceous, Feldberg et al. (2014) and Laenen et al. (2014) who did not employ this fossil as age constraint estimated a mean age of 126.76 Ma respective a median age of 135.73 Ma for Lepidolaenaceae and a mean age of 99.71 Ma respective median ages of 46.79-57.91 Ma for the stem of Gackstroemia.

\section{Family: Lejeuneaceae Cavers}

Lejeuneaceae represent the most species-rich family of liverworts and include ca. 1000 species in 72 currently accepted genera (e.g., Gradstein 2013, 2020, Bechteler et al. 2016, Wang et al. 2016). They are predominantly epiphytes and most diverse in humid tropical forests (Gradstein et al. 2001). The oldest putative fossil is the poorly preserved Middle Jurassic compression fossil Sinolejeunea yimaensis Yang \& Wu (2011: 229). Although its position in Lejeuneaceae 
is weakly supported by morphology, it is in accordance with the Late Triassic origin of Lejeuneaceae estimated by Feldberg et al. (2014), who did not use this fossil as an age constraint. The fossil record of Lejeuneaceae becomes more diverse in Cenozoic ambers, especially in Miocene Dominican and Mexican ambers. So far 17 extant genera are recognized (Grolle 1984a, b, c, d, 1993a, b, Gradstein 1993, Grolle et al. 2001, Ye \& Zhu 2010, Reiner-Drehwald et al. 2012, Heinrichs et al. 2014a, 2015a, 2016a, 2018b, Lee et al. 2015a, b, 2017, Kaasalainen et al. 2017, Sukkharak \& Gradstein 2017, Yu et al. 2020). The genera from Miocene Dominican and Mexican ambers represent all main lineages of modern Lejeuneaceae (Wilson et al. 2007, Yu et al. 2020) and provide some evidence that the cryptogamic communities of the Caribbean Miocene already resembled the extant ones (Heinrichs et al. 2014a, Kaasalainen et al. 2017).

Despite much progress in recent years, the classification of Lejeuneaceae is still a challenging task (Gradstein 2013). A particularly important feature are female involucres, which provide valuable information for recognizing genera and species, while sterile plants can sometimes only be classified to genus level (e.g., Heinrichs et al. 2015a). This offers some difficulties with the assignment of fossils as age constraints.

\section{Subfamily: Lejeuneoideae C.Massal.}

\section{Tribe: Brachiolejeuneeae van Slageren \& Berendsen}

\section{Subtribe: Brachiolejeuneinae Gradst.}

\section{Genus: Blepharolejeunea Arnell (1962: 335)}

\section{Blepharolejeunea obovata Gradstein (1993: 357)}

Holotype: MB.Pb.1984-805.

Reference: Gradstein (1993), fig. 2.

Age and stratigraphic level: 15-20 Ma, Langhian-Burdigalian (early to middle Miocene), La Toca Formation, Dominican Republic.

Calibration: Minimum age of Blepharolejeunea.

Justification: The truncate, bidentate lobule and the small cordate trigones are suggestive of the small montane Neotropical genus Blepharolejeunea, though the fossil does not match the morphology of any of the five extant species (Gradstein 1993). Main differences are the obovate outline of the lobule and the similar shape of the lobule teeth which are usually of a different size in extant species. The truncate lobule apex shows affinities to the closely related genus Brachiolejeunea (Spruce) Schiffner (1893: 128), though extant representatives of this genus are more robust, have squarrose leaves, and larger, imbricate underleaves with an arched insertion (Gradstein et al. 2001). This fossil has provided age constraints for the stem of the Brachiolejeunea/Blepharolejeunea-clade in Wilson et al. (2007) and for Blepharolejeunea in Laenen et al. (2014) who estimated median ages of 17.3-31.78 Ma.

\section{Subtribe: Stictolejeuneinae Gradst.}

\section{Genus: Neurolejeunea (Spruce) Schiffner (1893: 131)}

\section{Neurolejeunea macrostipula Gradstein (1993: 368)}

Holotype: MB.Pb.1984-812.

Reference: Gradstein (1993), fig. 9.

Age and stratigraphic level: 15-20 Ma, Langhian-Burdigalian (early to middle Miocene), La Toca Formation, Dominican Republic.

Calibration: Minimum age of Neurolejeunea.

Justification: Extant Neurolejeunea includes only four species and is mainly distributed in the Neotropics (Gradstein 1993, Gradstein et al. 2001, Pócs et al. 2015). Neurolejeunea macrostipula lacks ocelli, a character shared by the extant N. breutelii (Gottsche in Gottsche et al. 1845b: 324) Evans (1907: 13) which it resembles most (Gradstein 1993). It was employed as age constraint for the stem of Neurolejeunea in Wilson et al. 2007 and in Laenen et al. (2014) who estimated median ages of 5.48-10.9 Ma. 


\section{Genus: Stictolejeunea (Spruce) Schiffner (1893: 131)}

\section{Stictolejeunea squamata (Willd. ex F.Weber) Schiffner (1893: 131)}

Basionym: Jungermannia squamata Willd. ex Weber (1815: 33).-Type: West Indies, „In corticibus Myrti caryophyllatae”, sterile, unknown collector (S, STR, W hb. Lindenberg 6171 \& 6172); extant species.

Additional fossil specimen: MB.Pb.1984-1076.

Reference: Gradstein (1993), fig. 10.

Age and stratigraphic level: 15-20 Ma, Langhian-Burdigalian (early to middle Miocene), La Toca Formation, Dominican Republic.

Calibration: Minimum age of the extant species Stictolejeunea squamata.

Justification: Stictolejeunea squamata is an extant species also known as fossil from Dominican amber. The inclusion possibly represents a branch (Gradstein 1993) but can confidently be assigned because of its four cells wide ventral merophyte, the scattered ocelli in leaves and underleaves, the curved lobules with their opening turned towards the base of the stem, and the reniform, undivided underleaves with deeply arched insertion. The fossil has not yet been used as age constraint, but the age is mostly consistent with several divergence time estimates. Feldberg et al. (2014) estimated a mean stem age of $48.54 \mathrm{Ma}$ which is consistent with Wilson et al. (2007) who also estimated a middle Eocene origin. Laenen et al. (2014) estimated median ages of 5.48-10.9 Ma for Stictolejeunea.

\section{Tribe: Lejeuneeae Dumort.}

\section{Subtribe: Ceratolejeuneinae Gradst.}

\section{Genus: Ceratolejeunea (Spruce) Jack \& Stephani (1892: 16)}

Ceratolejeunea is a large pantropical genus with ca. 40 species and a center of diversity in the Neotropics (Dauphin 2003, Gradstein 2013, 2020, Heinrichs et al. 2014a). It is known from Miocene Dominican amber with one species identified only to genus level (Gradstein 1993, Feldberg et al. 2014) and three species from contemporaneous Mexican amber (Heinrichs et al. 2014a, 2015a, Lee et al. 2015b), which provide a minimum age for the genus.

\section{Ceratolejeunea antiqua Heinrichs \& Schäf.-Verw. in Heinrichs et al. (2014a: 11); Fig. 7A} Holotype: SMNS Mx 284.

Reference: Heinrichs et al. (2014a), figs. 1, 2.

Ceratolejeunea palaeomexicana (Grolle) Lee, Schäfer-Verwimp, Schmidt \& Heinrichs (2015b: 339) Basionym: Lejeunea palaeomexicana Grolle (1984d: 2).-Holotype: SMNS Mx-119-D-1.

References: Grolle (1984d), Abb. 1-10; Lee et al. (2015b), figs. 1-7; Heinrichs et al. (2018a), plate VII(6).

\section{Ceratolejeunea sublaetefusca Heinrichs, Pócs \& Schäf.-Verw. in Heinrichs et al. (2015a: 62)}

Holotype: SMNS Mx-443 (syninclusion Spruceanthus extinctus (Heinrichs, Gyarmati \& Schäf.-Verw. in Heinrichs et al. 2015a: 62) Gradstein \& Sukkharak, comb. nov.).

Reference: Heinrichs et al. (2015a), plate III.

Age and stratigraphic level: Ceratolejeunea antiqua, C. palaeomexicana, and C. sublaetefusca derive from 15-23 Ma, Langhian-Aquitanian (early to middle Miocene) amber mined in Simojovel, Chiapas, Mexico.

Calibration: Ceratolejeunea antiqua, C. palaeomexicana, and C. sublaetefusca provide a minimum age for Ceratolejeunea.

Justification: The presence of three species of Ceratolejeunea in Mexican amber and one only identified to genus level in contemporaneous Dominican amber as well as molecular phylogenetic studies indicate that this epiphytic genus was already diverse in the Miocene (Gradstein 1993, Feldberg et al. 2014, Scheben et al. 2016). Today, the genus shows a disjunct distribution and comprises pantropical species and regional endemics, whereas the center of diversity is South America (Scheben et al. 2016). Ceratolejeunea antiqua (Fig. 7A) shows morphological similarities to subgen. Ceratolejeunea and especially the species C. laetefusca (Austin 1876: 36) Schuster (1956: 306), C. cubensis 
(Montagne 1842: 481) Schiffner (1893: 125), and C. cornuta (Lindenberg 1829: 23) Stephani (1895: 65) (Dauphin 2003, Heinrichs et al. 2014a, Söderström et al. 2016). However, the fossil is sterile which hinders a comparison with the extant diversity. Another fossil with strong affinities to this subgenus is C. sublaetefusca which can only be separated from $C$. laetefusca and $C$. cubensis by the more bifid underleaves and more acute lobes. It might belong to the stem lineage of either species. Heinrichs et al. (2015a) could not entirely rule out that $C$. sublaetefusca is another fossil of an extant species, but again, the sterile condition of the fossil impedes the comparison with the extant diversity. The same problem occurs once more in the third species from Mexican amber, C. palaeomexicana. An assignment of these species within the crown group is therefore difficult. Some characteristic features like utriculi and perianths might be lacking, but the generic assignment is reliable, and the occurrence of Ceratolejeunea in Miocene ambers provides a minimum age for the genus. In Wilson et al. (2007) the presence of Ceratolejeunea sp. in Dominican amber (Gradstein 1993) was employed as constraint for the stem and in Feldberg et al. (2014) for the crown group resulting in a mean age of $36.53 \mathrm{Ma}$.

\section{Subtribe: Cheilolejeuneinae Gradst.}

\section{Genus: Cheilolejeunea (Spruce) Stephani (1890: 284)}

Cheilolejeunea is a large pantropical and mainly epiphytic genus with ca. 130 species (Ye et al. 2015, Bastos \& Gradstein 2020, Gradstein 2020). The fossil record of this genus is rather diverse, with one species described from Eocene Baltic amber (Grolle 1984c, Grolle \& Meister 2004b) and three from Miocene Dominican amber (Ye \& Zhu 2010, Heinrichs et al. 2018b, Grolle et al. 2001).

While the species from Baltic amber provides a minimum age for the genus, the three species from Miocene Dominican amber, namely C. antiqua (Grolle 1983: 2) Ye \& Zhu (2010: 280), C. lamyi Heinrichs, Schäfer-Verwimp, Renner \& Feldberg (2018b: 156), and C. suzannensis (Grolle 1984b: 27) Grolle \& R.L.Zhu in Grolle et al. (2001: 1073) cannot be assigned easily. A utilization of these fossils as age constraints would require assignments within the crown group what is currently difficult due to the complex taxonomy of Cheilolejeunea. Cheilolejeunea antiqua and $C$. suzannensis are known only in sterile condition what makes their assignment even more difficult, whereas $C$. lamyi has been described with a gynoecium lacking the perianth. The latter species has been identified by Grolle as the extant $C$. rigidula (Nees ex Montagne 1840: 336) Schuster (1971: 102) of subgen. Euosmolejeunea (Spruce 1884: 241) Kachroo (1968: 6) but differs in having partly subacute, slightly elongate leaf lobes, often apiculate underleaf lobes, and more acute lobes of the bracteole (Heinrichs et al. 2018b). Given an extensive sampling and thorough morphological studies it might be assigned to an extant subgenus.
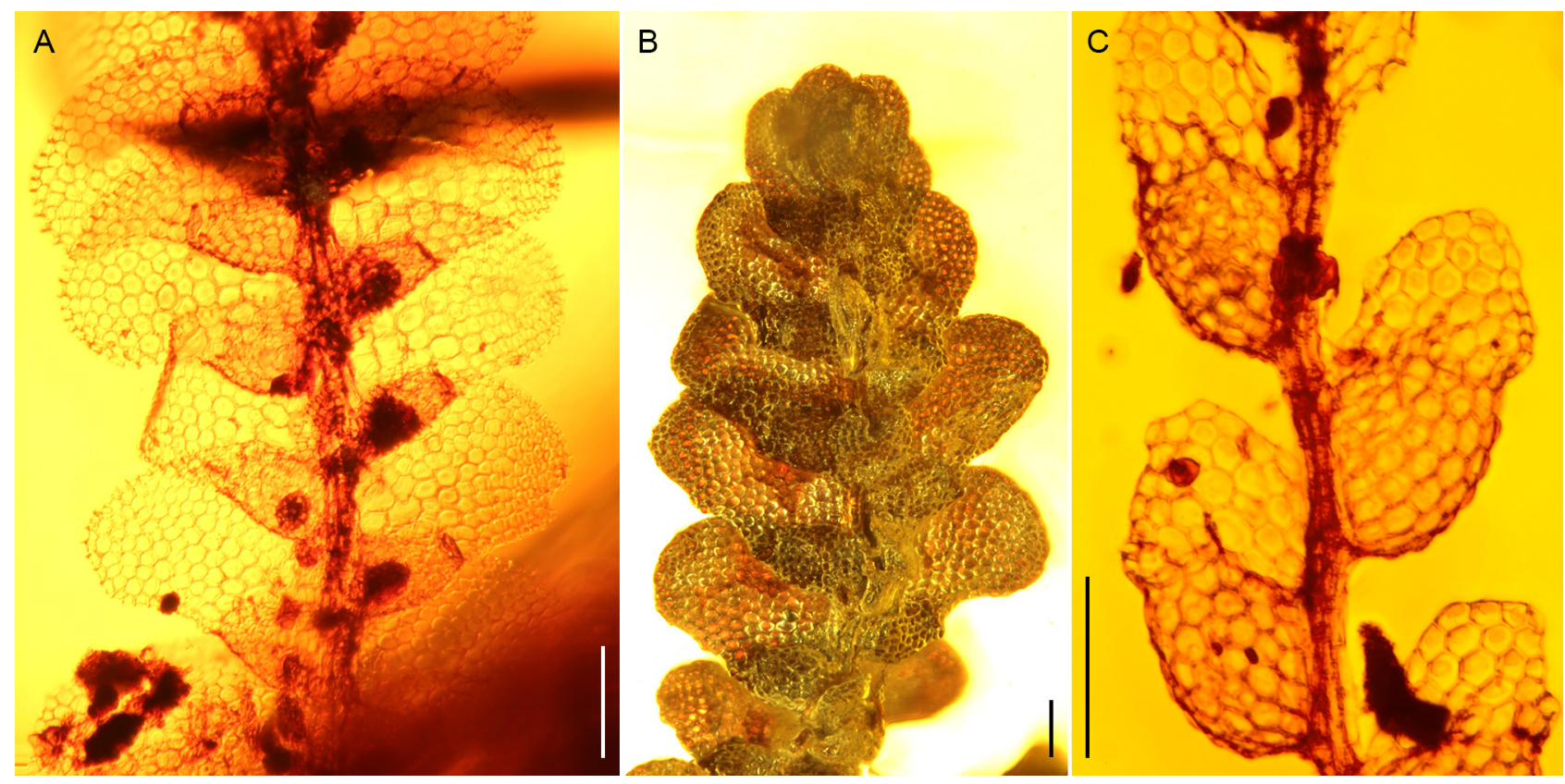

FIGURE 7. Lejeuneeae. A. Ceratolejeunea antiqua, SMNS Mx 284 (holotype) from Dominican amber in ventral view. B. Cheilolejeunea latiloba, GRÖHN 2065 from Baltic amber in ventral view. C. Microlejeunea nyiahae, AMNH-Tad-441-A (holotype) from Indian Cambay amber in ventral view. Scale bars: $A, C=100 \mu \mathrm{m}, \mathrm{B}=200 \mu \mathrm{m}$. 


\section{Cheilolejeunea latiloba (Casp.) Grolle (1984c: 230); Fig. 7B}

Basionym: Lejeunea latiloba Caspary (1887: 3).-Holotype: MB.Pb.1979/637 (Coll. Künow 69), Baltic amber.

= Lejeunea pinnata Caspary (1887: 3).-Holotype: MB.Pb.1979/471-G (Coll. Künow), Baltic amber (syninclusions Frullania acutata 471-C; Nipponolejeunea europaea 471-D-F; Radula sphaerocarpoides 471-A).-Syn. fide Grolle (1984c).

Additional specimens: Baltic amber: GRÖHN 2027, 2037, 2065, 2066, 2073, 2079, 2080, 2085; MB.Pb.1979/471B (Coll. Künow), MB.Pb.1979/471-H (Coll. Künow). Bitterfeld amber: MB.Pb.1997/3a-d, h (Coll. Grolle F/1a-d, h), MB.Pb.1997/19 (ser. 9/2a), MB.Pb.1997/41 (Coll. Grolle M-14/2), MB.Pb.1996/1349 (Coll. Striebich); GZG. BST.22068 (Coll. Grabenhorst Le-61).

References: Caspary (1887), Tafel I Bild 9 as Lejeunea latiloba, Tafel I Bild 26 as Lejeunea pinnata; Caspary \& Klebs (1907), Tafel III Bild 23, 23a, b as Lejeunea latiloba; Barthel \& Hetzer (1982), Tafel 1, Fig. 2a as Lejeunea latiloba; Grolle (1984c), Abb.1, Tafeln XXXI-XXXVI; Grolle \& Meister (2004b), plate 2e-g.

Age and stratigraphic level: 34-41 Ma, Priabonian-Bartonian (Eocene), Baltic region; and $24 \mathrm{Ma}$, Chattian (late Oligocene), Bernsteinschluff Horizon in the upper part of the Cottbus Formation of the Goitzsche mine, Bitterfeld, Germany.

Calibration: Minimum age of Cheilolejeunea.

Justification: Well-preserved fossils of C. latiloba are frequently found in Baltic and Bitterfeld amber. The ventral merophyte of the thin stem is ca. 2 cells wide, the cells of the lateral leaves have slightly thickened walls, the lobules have a large tooth on the outer margin and show a probable insertion point of a hyaline papilla, the underleaves are bifurcated, and one specimen has unfertilized gynoecia with gynoecial innovations of the Pycnolejeunea-type but without perianth (Grolle 1984c, Grolle \& Meister 2004b). Morphologically it resembles the extant Azorean endemic C. cedercreutzii (Buch \& Persson 1941: 9) Grolle (1976: 188) of subg. Euosmolejeunea (Grolle 1984c, Grolle \& Meister 2004b, Söderström et al. 2016). The holotype is preserved in a taphocoenosis with Radula sphaerocarpoides, Nipponolejeunea europaea, and Frullania acutata as well as several insects and provides an excerpt of an Eocene bark community (Grolle 1984c). The rather complete preservation substantiates the generic assignment, and the species has been employed as age constraint in several divergence time estimates (Heinrichs et al. 2007, Wilson et al. 2007, Cooper et al. 2012, Feldberg et al. 2014, Laenen et al. 2014). Feldberg et al. (2014) assigned the fossil to the crown group and estimated a mean age of 43.89 Ma. Laenen et al. (2014) estimated median ages for Cheilolejeunea of 19.85-25.14 Ma.

\section{Subtribe: Cololejeuneinae Gradst.}

\section{Genus: Cololejeunea (Spruce) Stephani (1891: 208)}

\section{Cololejeunea sp.}

Specimen: OSU Poinar B 1-23, holotype of Phyllopsora dominicanus Rikkinen in Rikkinen \& Poinar (2008: 1008). Reference: Rikkinen \& Poinar (2008).

Age and stratigraphic level: 15-20 Ma, Langhian-Burdigalian (early to middle Miocene), La Toca Formation, Dominican Republic.

Calibration: Minimum age of Cololejeunea.

Justification: The liverwort inclusion in this amber specimen has not yet been described, but the complicate-bilobed, incubously inserted leaves and the lack of underleaves are indicative of Cololejeunea. However, for a final assignment to this genus and the description of a new species it would be necessary to determine the lateral to ventral merophyte ratio. The presence of this mainly epiphyllous genus in Dominican amber provided an age constraint for Feldberg et al. (2014) who assigned it to the crown group of the genus and estimated a mean age of 63.31 Ma.

\section{Subtribe: Cyclolejeuneinae Gradst.}

Genus: Cyclolejeunea Evans (1904: 193)

\section{Cyclolejeunea archaica Grolle (1984a: 274)}

Holotype: SMNS Do-3868-B-1.

Reference: Grolle (1984a), Abb. 1E-G, Taf. 3, 4.

Age and stratigraphic level: 15-20 Ma, Langhian-Burdigalian (early to middle Miocene), La Toca Formation, Dominican Republic. 
Calibration: Minimum age of Cyclolejeunea.

Justification: The lateral leaves of the fossil have cells with one central mammilla and thin cell walls without trigones. These characters can only be found in the extant Lejeunea sect. Echinocolea (Schuster 1963: 125) Gradstein (2018: 7) and in C. accedens (Gottsche in Gottsche et al. 1845b: 339) Evans (1904: 201). Gynoecia or vegetative propagules might be lacking but the overall similarity to the latter species provides a reliable classification (Grolle 1984a). This fossil has been used as age constraint in Laenen et al. (2014) who estimated median ages of 31.7-42.54 Ma.

\section{Subtribe: Drepanolejeuneinae Gradst.}

Genus: Drepanolejeunea (Spruce) Stephani (1891: 209)

\section{Drepanolejeunea eogena Grolle (1993b: 376)}

Holotype: SMNS Do-3927-M-11.

Reference: Grolle (1993b), figs. 1, 2.

Age and stratigraphic level: 15-20 Ma, Langhian-Burdigalian (early to middle Miocene), La Toca Formation, Dominican Republic.

Calibration: Minimum age of Drepanolejeunea.

Justification: The presence of ocelli is not clear, but the fertile fossil can be assigned to Drepanolejeunea with high confidence because of the bifid underleaves with lanceolate lobes, a perianth with irregularly toothed folds, and the pycnolejeuneoid gynoecial innovation (Grolle 1993b). There is no extant species closely related to the fossil; therefore, it might provide a minimum constraint for the genus. It has already been used in Wilson et al. (2007) for a clade comprising Drepanolejeuneinae and Cololejeuneinae, a group which includes many mainly epiphyllous genera.

\section{Subtribe: Lejeuneinae Gradst.}

Genus: Lejeunea Libert (1820: 373)

In recent years, molecular phylogenetic studies have greatly refined the classification of this large pantropical genus which comprises ca. 300 extant species, but to date it remains taxonomically difficult (e.g., Wilson et al. 2007, Gradstein 2013, Heinrichs et al. 2013, Lee 2013, Renner et al. 2013c, Lee et al. 2020). Four fossil species described from Dominican amber suggest a high diversity of Lejeunea in the Miocene Caribbean forest (Kaasalainen et al. 2017, Lee et al. 2017) what is in good accordance with the Miocene origin estimated for this genus (Heinrichs et al. 2016a). However, all fossils are sterile, which makes comparisons with extant taxa problematic.

Lejeunea hamatiloba G.E.Lee, Schäf.-Verw., M.A.M.Renner \& Heinrichs in Lee et al. (2017: 147) Holotype: MB.Pb.2016/1865.

Reference: Lee et al. (2017), plates I.1, II.1, 2, fig. 1.

Lejeunea miocenica Heinrichs, Schäf.-Verw., M.A.M.Renner \& G.E.Lee in Kaasalainen et al. (2017: 323) Holotype: AMNH DR-15-3.

Reference: Kaasalainen et al. (2017), figs. 1B, 3.

Lejeunea resinata G.E.Lee, Schäf.-Verw., M.A.M.Renner \& Heinrichs in Lee et al. (2017: 147) Holotype: MB.Pb.2016/1866.

Reference: Lee et al. (2017), plates I.2, II.3, 4, fig. 2.

Lejeunea urbanioides G.E.Lee, Schäf.-Verw., M.A.M.Renner, Heinrichs in Lee et al. (2017: 148) Holotype: NMNH 372452.

References: Reiner-Drehwald et al. (2012) as Lejeunea sp.; Lee et al. (2017), plates I.3, II.5, 6, fig. 3. 
Age and stratigraphic level: Lejeunea hamatiloba, L. miocenica, L. resinata, and L. urbanioides derive from 15-20 Ma, Langhian-Burdigalian (early to middle Miocene) amber mined in the La Toca Formation, Dominican Republic. Calibration: Lejeunea hamatiloba, L. miocenica, L. resinata, and L. urbanioides provide a minimum age for Lejeunea.

Justification: Though all fossils are sterile, the generic assignment is reliable (Lee et al. 2017). The plants are characterized by two cells wide merophytes, long-inserted leaf lobes, small, toothed lobules, the lack of differentiated ocelli, and bifid underleaves (Kaasalainen et al. 2017, Lee et al. 2017). Lejeunea miocenica shows characters typical of the polyphyletic subgen. Crossotolejeunea Spruce (1884: 161) (Kaasalainen et al. 2017, Reiner-Drehwald \& Goda 2000 ) which is a common element of the Caribbean rainforests today. The presence of a typical Lejeunea in Dominican amber provided a minimum age constraint for the crown group in Feldberg et al. (2014) who estimated a mean age of 51.59 Ma. Heinrichs et al. (2007) and Laenen et al. (2014) assigned L. palaeomexicana from Mexican amber to the genus, a species which has been transferred to Ceratolejeunea. However, since Mexican and Dominican amber are contemporaneous this assignment resulted in the same constraint with median ages of 25.19-34.15 Ma estimated in Laenen et al. (2014) for the genus. Lee et al. (2020) did not employ any Lejeunea fossil due to the difficulties in assigning them to any extant subclade of the genus but used Microlejeunea nyiahae Heinrichs, G.E.Lee, Schäf.-Verw. \& A.R.Schmidt in Heinrichs et al. (2016a: e0156301 [5]) from 52 Ma Indian amber as minimum age constrain for the stem, what resulted in estimates of 42.2-52 Ma for the Lejeunea crown group.

\section{Genus: Microlejeunea (Spruce) Stephani (1888a: 61)}

Recent molecular phylogenetic studies clearly separate this pantropical genus from Lejeunea (e.g., Dong et al. 2013, Heinrichs et al. 2013, Lee et al. 2020). Fossil material has been described from Eocene Indian amber and Miocene Dominican amber. Microlejeunea nyiahae represents the oldest crown group member of Lejeuneaceae (Heinrichs et al. 2016a, Lee et al. 2020). A much younger fossil also assigned to this genus is M. miocenica Lee, Bechteler, SchäferVerwimp \& Heinrichs (2015a: 17) which is preserved with juvenile gynoecia characterized by winged bracts which substantiate an assignment to this genus. It does not closely match the morphology of any extant Neotropical species but somewhat resembles the extant M. subulistipa Stephani (1896b: 115) in its vegetative characters, and M. epiphylla Bischler (1963: 378) as well as M. aligera (Mitten 1860a: 113) Stephani (1915: 827) in having toothed female bracts. Currently, it cannot be assigned to any taxon within the crown group.

\section{Microlejeunea nyiahae; Fig. 7C}

Holotype: AMNH-Tad-441-A.

Reference: Heinrichs et al. (2016a), figs. 1A, 2, 3.

Age and stratigraphic level: $52 \mathrm{Ma}$, Ypresian (early Eocene), Tadkeshwar Lignite Mine of Gujarat State, India (Cambay amber).

Calibration: Minimum age of tribe Lejeuneeae.

Justification: The sterile specimens (Fig. 7C) are in good accordance with the circumscription of Microlejeunea, except that the presence of ocelli can neither be confirmed nor rejected because they do not differ in size from the surrounding cells in this genus, and because oil bodies are mostly not preserved in fossils (Heinrichs et al. 2016a). It is also possible that this fossil belongs to Lejeunea, though paleotropical representatives are only present in early diverging lineages of Microlejeunea but not of Lejeunea. In their divergence time estimation, Heinrichs et al. (2016a) conducted a thorough cross evaluation of different assignments of this fossil and the assumption of an early crown or stem group member of Microlejeunea or Lejeunea led to the most likely age estimates. The genera of Lejeuneinae might have been established Late Cretaceous or Paleogene, while the crown group of Lejeuneaceae genera diversified in Cenozoic, angiospermdominated forests. The fossil was also employed by Lee et al. (2020) to constrain the Microlejeunea-Lejeunea clade.

Subfamily: Ptychanthoideae Mizut.

Genus: Acrolejeunea (Spruce) Schiffner (1893: 128)

Acrolejeunea ucrainica Mamontov, Heinrichs \& Schäf.-Verw. in Mamontov et al. (2013: 95); Fig. 8 Holotype: SIZK-K-10052F. 
= Frullania ucrainica Konstant. \& Ignatov in Konstantinova et al. (2012: 269).- - Holotype: SIZK-K-6581. - Syn. nov.

References: Mamontov et al. (2013), figs. 1-10; Konstantinova et al. (2012), figs. 11-14.

Age and stratigraphic level: 35-37 Ma, Priabonian (late Eocene), amber quarry "Pugach", Klesov, Ukraine (Rovno amber).

Calibration: Minimum age of Acrolejeunea.

Justification: Acrolejeunea is a pantropical genus of ca. 20 extant species which occur as epiphytes in rather dry environments (Gradstein 1975, Wang et al. 2014). The holotype is sterile but vegetative characters like the suberect upper shoot sector with small leaves, the subvertically positioned, squarrose leaves with revolute dorsal margins, the arrangement of the lobe cells in curved rows which parallel the dorsal margin, and the presence of cordate trigones as well as intermediate thickenings distinguish it from other fossil representatives of Ptychanthoideae and are typical for Acrolejeunea (Mamontov et al. 2013).

Another fossil from the same locality, which has initially been described as Frullania ucrainica, also belongs to A. ucrainica and is fertile (female, Fig. 8A). It is characterized by densely imbricate leaves, undivided reniform underleaves, elongate cells, as well as inflated Lejeunea-type lobules with a long, arched keel (Fig. 8B). While species of Frullania, including those with wide and entire underleaves, have shallowly to deeply bilobed, more or less elongated female bracteoles (Hattori 1973, Schuster 1992), the fossil has a very wide and undivided innermost female bracteole which is rather similar to underleaves of vegetative parts, a character typical for Ptychanthoideae. Also, the presence of a pluriplicate perianth (Fig. 8A) is indicative of Ptychanthoideae.

The presence of two innovations below the gynoecium indicates that A. ucrainica might be a member of sect. Trocholejeunea (Schiffn. in Dixon et al. 1932: 160) Jian Wang bis \& Gradst. in Wang et al. (2014: 38). It is very similar to the extant A. sandvicensis (Gottsche 1857: 344) Stephani (1896a: 312) as suggested by Sun et al. (2018). Acrolejeunea sect. Trocholejeunea is a small group of species with an extant distribution in subtropical and warmtemperate regions of East Asia (Wang et al. 2014). Its occurrence in Rovno amber indicates that the section was more widespread in the Holarctics during the late Eocene. The crown group of Acrolejeunea diversified in the Paleogene (e.g., Laenen et al. 2014). Hence, the Eocene amber inclusion could represent either a member of the stem or the crown group.

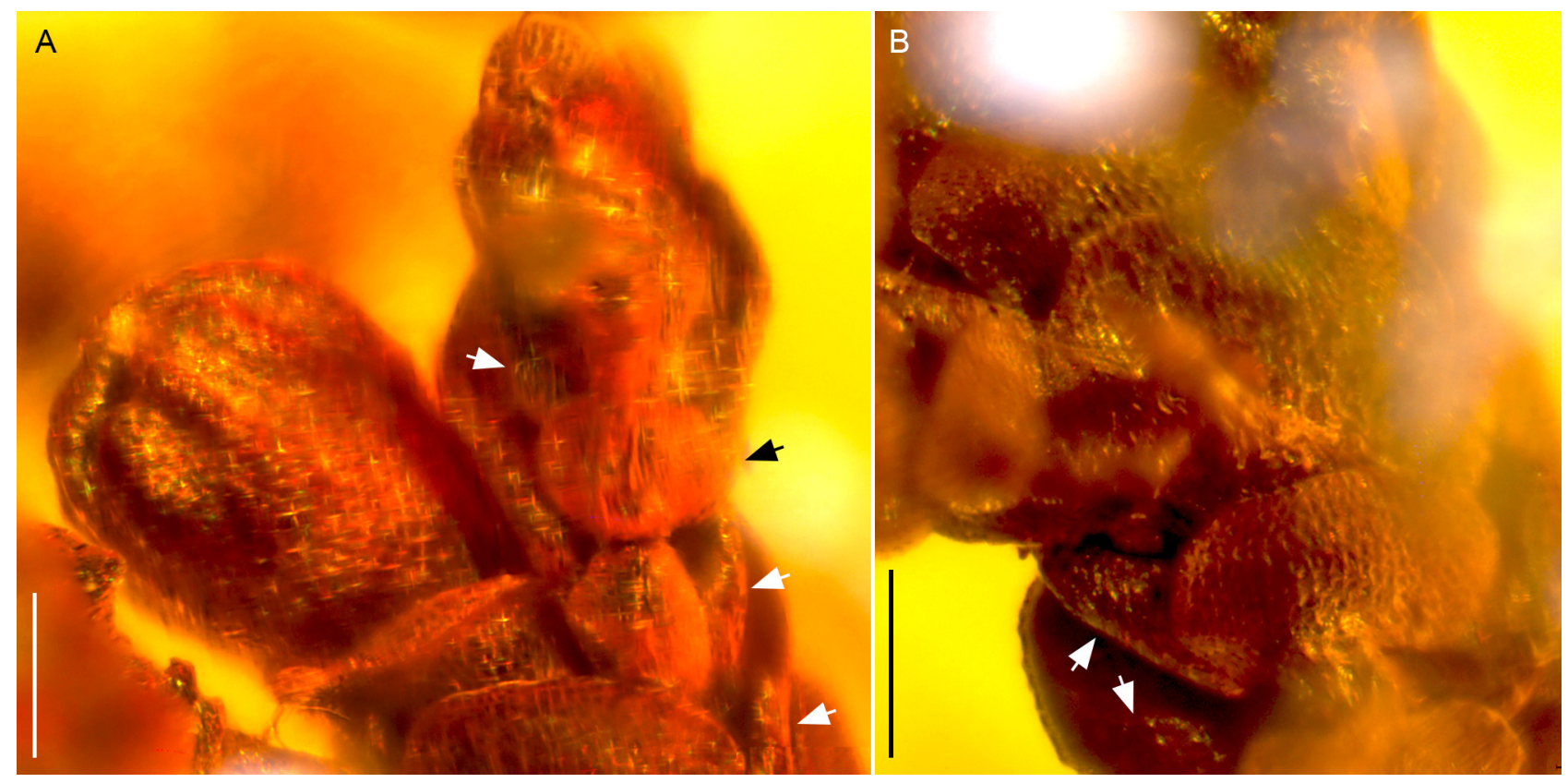

FIGURE 8. Lejeuneaceae subfam. Ptychanthoideae. A, B. Acrolejeunea ucrainica, SIZK-K-6581 (holotype of the synonymous species Frullania ucrainica) from Rovno amber. A. Perianth and subgynoecial innovation with Lejeunea-type lobules of lateral leaves and undivided underleaves. B. Detail of shoot in ventral view showing Lejeunea-type lobules of lateral leaves and large undivided underleaves. Black and white arrows indicate lobules of lateral leaves. Scale bars: A, B=200 $\mu \mathrm{m}$.

\section{Genus: Bryopteris (Nees) Lindenb. in Gottsche et al. (1845a: 284)}

Bryopteris, with two species in tropical America and one in Madagascar, is a common element of the montane and submontane rainforests of the Neotropics (Grolle 1993a, Gradstein 2020, Gradstein et al. 2001) and morphologically 
well differentiated. Two species have been described from Dominican amber and provide a minimum age for the genus.

\section{Bryopteris bispinosa Grolle (1993a: 73)}

Holotype: SMNS Do-3924-M-2.

References: Grolle (1993a), Abb. 1, 2; Heinrichs et al. (2018a), plate VI(1, 2).

\section{Bryopteris succinea Grolle (1984a: 271)}

Holotype: SMNS Do-4128-M-1.

References: Grolle (1984a), Abb. 1A-D, Taf. 1, 2; Heinrichs et al. (2018a) Plate VI(3).

Age and stratigraphic level: Bryopteris bispinosa and B. succinea derive from 15-20 Ma, Langhian-Burdigalian (early to middle Miocene) amber mined in the La Toca Formation, Dominican Republic.

Calibration: Bryopteris bispinosa and B. succinea provide a minimum age for Bryopteris.

Justification: The species from Dominican amber can be assigned to the genus with high confidence. Bryopteris bispinosa closely resembles the extant Neotropical B. diffusa (Swartz 1788: 144) Nees in Gottsche et al. (1845a: 286) which is the only extant species with long teeth similar to the fossil on the lobules (Grolle 1993a). An assignment to the stem or crown of this species might therefore be justified. The fossil only differs in having coarsely toothed lobes while $B$. diffusa generally has entire lobes, rarely with a few small teeth near the apex (Gradstein 1994). Bryopteris succinea has entire leaf lobules and resembles B. filicina (Swartz 1788: 145) Nees in Gottsche et al. (1845a: 284). It might provide an age constraint for this taxonomically complicated species (e.g., Hartmann et al. 2006) though a clear morphological differentiation from the sister clade B. gaudichaudii Gottsche (1857: 340) would be necessary.

The presence of Bryopteris in Dominican amber has provided an age constraint for the genus in Wilson et al. (2007) and also in Laenen et al. (2014) who estimated median ages of 10-20.28 Ma. However, assignments within the crown group might also be possible, given enhanced molecular datasets combined with morphological studies.

\section{Genus: Dibrachiella (Spruce) Shi, Zhu \& Gradstein (2015: 888)}

\section{Dibrachiella grollei (Gradst.) Gradstein, comb. nov.}

Basionym: Archilejeunea grollei Gradstein (1993: 354).--Holotype: MB.Pb.1984-1074.

Reference: Gradstein (1993), fig. 1.

Age and stratigraphic level: 15-20 Ma, Langhian-Burdigalian (early to middle Miocene), La Toca Formation, Dominican Republic.

Calibration: Minimum age of Dibrachiella.

Justification: Dibrachiella is a genus of nine species that is distributed in tropical America and Africa (Gradstein 2020). Previously the genus was treated as a subgenus of Archilejeunea (Spruce) Stephani (1888b: 113) but molecular analysis showed that Archilejeunea is polyphyletic and that Dibrachiella merits generic status (Shi et al. 2015).

The fertile fossil can be assigned to the genus with high confidence but has not yet been employed in divergence time estimates. It is morphologically similar to the extant $D$. parviflora (Nees 1833a: 353) Shi, Zhu \& Gradstein (2015: 889) though there are differences in the female involucre (Gradstein 1993). It is a possible constraint of the Dibrachiella-Spruceanthus-clade (Shi et al. 2015) and has been employed as age constraint in Wilson et al. (2007) for the stem of Archilejeunea.

\section{Genus: Lopholejeunea (Spruce) Stephani (1890: 285)}

\section{Lopholejeunea subnigricans Gradstein (1993: 359)}

Holotype: MB.Pb.1985-2.

Reference: Gradstein (1993), fig. 4.

Age and stratigraphic level: 15-20 Ma, Langhian-Burdigalian (early to middle Miocene), La Toca Formation, Dominican Republic.

Calibration: Minimum age of Lopholejeunea.

Justification: Lopholejeunea is one of the larger pantropical genera with ca. 35 species (Gradstein 2020). Neotropical species occur in lowland and lower montane rainforests where they grow as bark epiphytes or on rock. The fossil 
matches typical extant representatives of Lopholejeunea in having undivided underleaves, isodiametric leaf cells, blackish cell walls, and large epidermis cells on the stem (Gradstein 1993). It is very similar to L. nigricans (Lindenb. in Gottsche et al. 1845b: 316) Schiffner (1898: 293), a species widely distributed throughout the tropics, whereas the fossil has smaller and more flattened lobules instead of swollen ones, a more conspicuous tooth, smaller leaf cells, and strongly squarrose underleaves. This fossil has been employed as a minimum age constraint for the crown group in Feldberg et al. (2014) resulting in a mean age of 22.15 Ma. Laenen et al. (2014) did not employ this fossil as a constraint but estimated similar median ages of 18.99-29.94 Ma.

\section{Genus: Marchesinia Gray (1821: 689)}

The Afro-American genus is represented by two fossil species in Miocene Dominican amber, one extinct and one extant. Contrary to the extant M. brachiata (Swartz 1788: 144) Schiffner (1893: 128), the extinct M. pusilla Gradstein (1993: 362) cannot be as easily assigned within the crown group of the genus. The lobule is suggestive of M. brachiata, but the ovate-concave leaves and small size are more similar to the African M. excavata (Mitten 1860b: 58) Schiffner (1893: 128) (Gradstein 1993). The fossil seems to deviate from both taxa by its large, contiguous trigones which are never radiate and by the lack of intermediate thickenings.

\section{Marchesinia brachiata}

Basionym: Jungermannia brachiata.-Type: Jamaica, Swartz s.n. (Holotype, S; Isotypes, BM, E, S); extant species.

Additional fossil specimen: MB.Pb.1985-1262.

References: Heinrichs et al. (2009); Gradstein (1993), fig. 5; Gradstein (2012).

Age and stratigraphic level: 15-20 Ma, Langhian-Burdigalian (early to middle Miocene), La Toca Formation, Dominican Republic.

Calibration: Minimum age of the extant species Marchesinia brachiata.

Justification: The fossil specimen is sterile but shows the characteristic features of the extant species complex (Gradstein 1993, 2012): a robust stem with a ventral merophyte eight cells wide, large, flattened lobules which probably bear more than one tooth along the free margin, isodiametric cells with small radiate trigones as well as intermediate thickenings, and large underleaves with deeply arched insertion. The fossil cannot be distinguished from the extant species and provides a reliable minimum age.

Marchesinia has been employed as age constraint in Wilson et al. (2007), in Laenen et al. (2014) who estimated median ages of 45.5-63.4 Ma for this genus, and in Feldberg et al. (2014) who estimated a mean age of 47.29 Ma.

\section{Genus: Spruceanthus Verdoorn (1934: 151)}

Extant Spruceanthus comprises 16 species and is distributed in tropical Asia and Australia with only one species occurring in the Neotropics and one in West Africa (Wang et al. 2015, Sukkharak \& Gradstein 2017, Gradstein 2020). The plants are mainly epiphytes in humid environments. Two fossils of this genus are known from Eocene Baltic and Miocene Mexican amber (Grolle 1985c, Heinrichs et al. 2015a). The Eocene fossil provides a reliable minimum age for the genus, while the Miocene fossil cannot be easily assigned within the crown group. It has been described as Mastigolejeunea extincta Heinrichs, Gyarmati \& Schäf.-Verw. in Heinrichs et al. (2015a: 62) but its morphology does not fit the description of Thysananthus Lindenb. in Lehmann (1844: 24) subgen. Mastigolejeunea (Spruce 1884: 100) Sukkharak \& Gradstein (2017: 101); therefore, we transfer it to Spruceanthus and provide an emended description based on new fossil material.

Spruceanthus extinctus (Heinrichs, Gyarmati \& Schäf.-Verw.) Gradstein \& Sukkharak, comb. nov.; Fig. 9 Basionym: Mastigolejeunea extincta.-Holotype: SMNS Mx-443.

Additional specimens: GRÖHN 10410, 10411.

Reference: Heinrichs et al. (2015a), plate II.

Age and stratigraphic level: 15-23 Ma, Langhian-Aquitanian (early to middle Miocene), Simojovel, Chiapas, Mexico. 
A

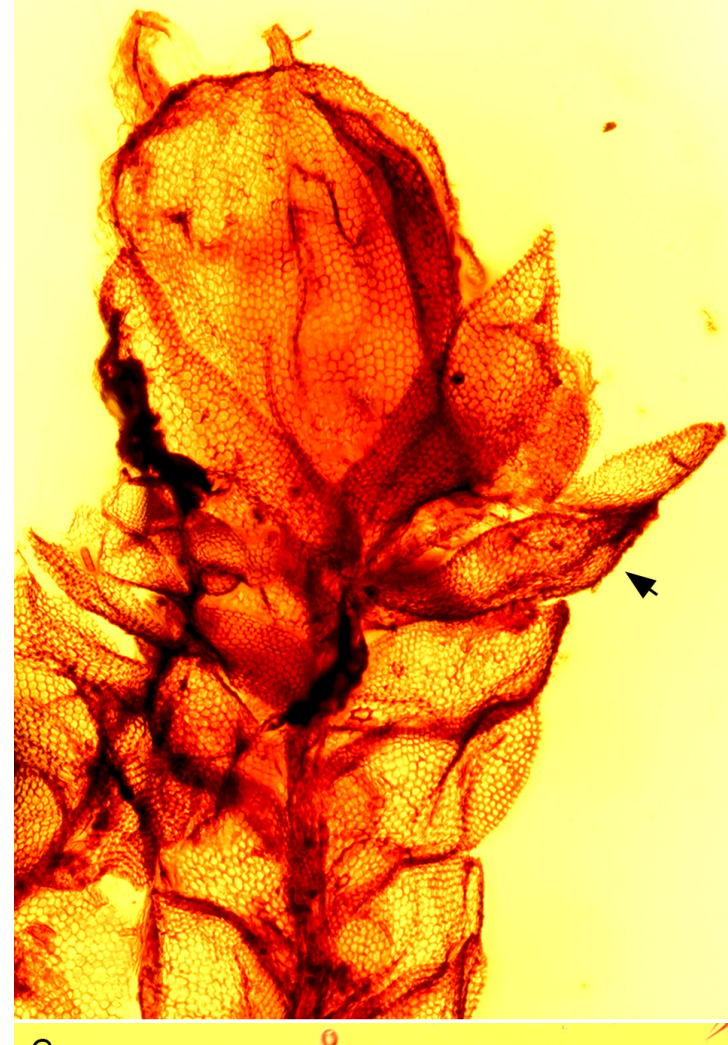

C

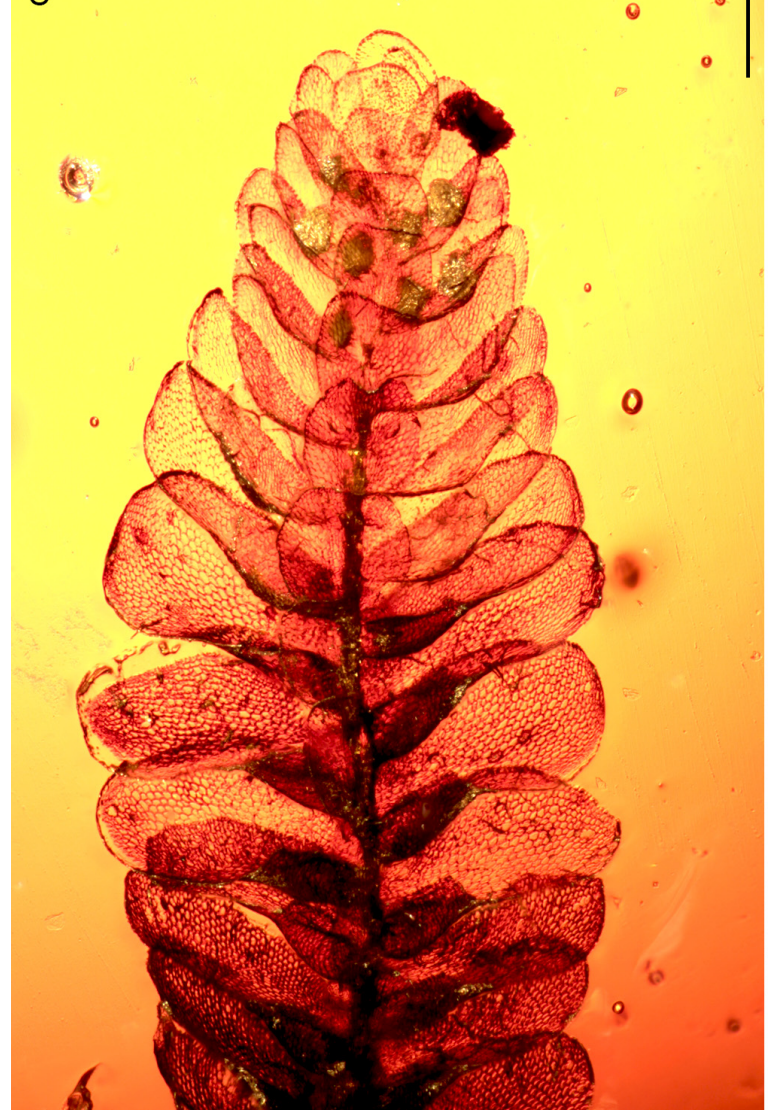

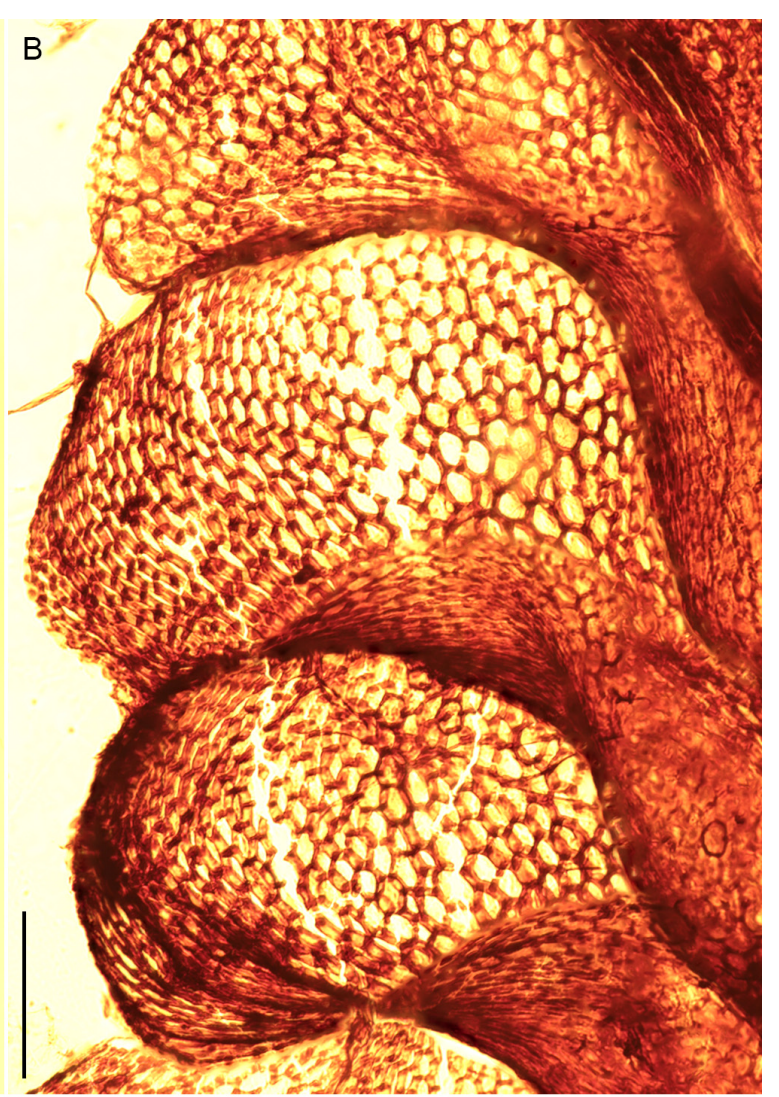

D 
Emended diagnosis: Incubously foliated liverwort with a ventral merophyte ca. 4-6 cells wide, complicate bilobed leaves consisting of a $0-1$ toothed inflated lobule folded against the lobe and an oblong-ovate dorsal lobe with rounded to obtuse apex, mostly isodiametric leaf cells with small triangular trigones, and obdeltoid underleaves; androecia terminal, consisting of ca. 6 pairs of bracts with hypostatic ventral lobules almost as long as the dorsal lobe and 1-2 antheridia per bract; gynoecium terminal, with 1 subfloral innovation, erect-spreading bracts with acute lobes, and a large, beaked, smooth perianth with 5-6 smooth and irregularly developed folds.

Emended description: Upper portion of female holotype $4 \mathrm{~mm}$ long, $0.6-0.7 \mathrm{~mm}$ wide, brown. Stem $50-60 \mu \mathrm{m}$ in diameter, cortical cells thick-walled and elongate; ventral merophyte ca. 4-6 cells wide. Leaves convex, lobes oblong-ovate (Fig. 9A-C), ca. 0.4-0.45 ×0.25-0.3 mm, apex rounded or obtuse, median leaf lobe cells $14-25(-30) \times$ $12-18 \mu \mathrm{m}$ (Fig. 9B), trigones small, triangular; lobules about $0.30-0.45$ the length of the lobe (Fig. 9C), inflated, with apex often merging into ventral lobe margin, without or with a single tooth on free margin. Underleaves (remote to) moderately imbricate (Fig. 9C, D), concave and somewhat squarrose, obdeltoid, symmetrical, the margins contracted at the base, ca. $0.2 \mathrm{~mm}$ long $\times 0.22-0.30 \mathrm{~mm}$ wide, apex plane or recurved, emarginate. Androecia [specimen GRÖHN 10410; Fig. 9C, D] terminal, consisting of ca. 6 pairs of bracts with hypostatic ventral lobules almost as long as the dorsal lobe, apices broadly rounded; bracteoles present throughout androecium, similar to underleaves of vegetative shoot part, antheridia visible in the axils of five bracts (Fig. 9D), 1-2 per bract, globose. Gynoecium with 1 subfloral innovation (Fig. 9A), bracts erect-spreading, lobes ca. $0.6 \mathrm{~mm}$ long, triangularly-ovate, acute, ending in a 1 cell long, blunt, uniseriate tip, bracteole \pm as long as bracts, ca. $0.6 \mathrm{~mm}$ long $\times 0.45 \mathrm{~mm}$ wide, obovate, apex emarginate. Perianth emergent, $0.75 \mathrm{~mm}$ long $\times 0.57 \mathrm{~mm}$ wide, obovate, flattened, with 5-6 smooth and irregularly developed folds; beak $75 \mu \mathrm{m}$ long. Sporophyte unknown.

Calibration: Possible future calibration point within the genus, once the precise assignment will be possible.

Justification: The generic placement of Mastigolejeunea extincta was discussed by Sukkharak \& Gradstein (2017), who suggested that the species might be a member of Lopholejeunea because of the mostly isodiametric leaf cells (Fig. 9B), narrow underleaf base, absence of true innovations, and lack of a high median keel on the ventral perianth surface. Nevertheless, the 5-6 smooth and irregularly developed folds on the perianth of M. extincta (Fig. 9A) are abnormal for Lopholejeunea, which normally produces 4 or 5 toothed keels (very rarely keels almost entire) and are more suggestive of Spruceanthus (Wang et al. 2016). Moreover, the short branch in the gynoecium of M. extincta (Fig. 9A), interpreted by Sukkharak \& Gradstein (2017) as a "pseudo-innovation", is in fact probably a true innovation because of its position at the base of the inner bract (Heinrichs et al. 2015a). Presence of true innovations also separates Spruceanthus from Lopholejeunea. Because of this evidence, M. extincta is transferred to the genus Spruceanthus. Two further fossils of S. extinctus have been found in Mexican amber (GRÖHN 10410, 10411), including one shoot with mature androecia (GRÖHN 10410). The androecia (Fig. 9C, D) are terminal on the shoot and consist of six pairs of bracts. The bract lobules are hypostatic and almost as long as the lobe, with a broadly rounded apex of lobules, and the bracteoles are similar to the underleaves and are present throughout the male spike (Fig. 9C). The antheridia are globose and 1-2 per bract (Fig. 9D). Spruceanthus extinctus is the second fossil species of this genus described from amber and the first one from tropical America. The utilization of S. extinctus as age constraint requires an assignment within the crown group of the genus and hence a thorough comparison with extant species.

\section{Spruceanthus polonicus Grolle (1985c: 79)}

Holotype: WAR-MZ Coll. Rieband 469-2.

Additional specimen: Baltic amber: cf. GRÖHN 5808.

References: Grolle (1985c), plates I, II, fig. 1; Grolle \& Meister (2004b), plate 23f, g; Frahm \& Gröhn (2013), figs. 9,10 .

Age and stratigraphic level: $34-41 \mathrm{Ma}$, Priabonian-Bartonian (Eocene), Baltic region.

Calibration: Minimum age of Spruceanthus.

Justification: Spruceanthus polonicus is known with gynoecium and is morphologically very similar to the extant S. semirepandus (Nees 1830: 39) Verdoorn (1934: 153) in having entire margined vegetative lateral leaves and underleaves, an irregularly dentate subinvolucral underleaf, and a bract and bracteole with coarse thorny teeth (Grolle 1985c). It differs in having lobules $0.3-0.4 \times$ the size of the lobe instead of $0.25 \times$ and entire instead of 1-3 dentate lobule apices. Spruceanthus polonicus has been employed as age constraint in Heinrichs et al. (2007), Wilson et al. (2007), Feldberg et al. (2014), and Laenen et al. (2014) for the stem of Spruceanthus. 


\section{Genus: Thysananthus}

Thysananthus is a largely paleotropic genus with ca. 30 species (e.g., Sukkharak \& Gradstein 2017). One fossil species has been described from Baltic as well as Bitterfeld amber and three species are known from Dominican amber, one of them representing an extant species. One extinct species from Dominican amber, T. bidentulus (Gradstein 1993: 365) Sukkharak \& Gradstein (2017: 103), is preserved only in sterile condition and difficult to assign to an extant lineage within the crown group. The second extinct species, T. weiweianus N.-N.Yu \& Gradst. in Yu et al. (2020: 59), is preserved with androecia, gynoecia, and perianth. The species closely resembles the extant $T$. plicatiflorus (Spruce 1884: 104) Sukkharak \& Gradstein (2017: 102) but differs in the larger lobules, autoicous sexuality, and the somewhat expanded keels and plicae of the perianth (Yu et al. 2020). The fertile condition might allow an assignment within the crown group.

Except for the newly described T. weiweianus, all species have previously been assigned to Mastigolejeunea which has been lowered to a subgenus of Thysananthus (Sukkharak \& Gradstein 2017). The subgenera Mastigolejeunea and Thysananthus are not easily distinguished even when fertile material is at hand, therefore the assignment of the extinct species is difficult.

\section{Thysananthus auriculatus (Wilson \& Hook.) Sukkharak \& Gradstein (2017: 102)}

Basionym: Jungermannia auriculata Wilson \& Hook. in Wilson (1841: no. 170).-Type: USA, Louisiana, New Orleans, Drummond s.n., Musci Americani (Southern States) 170 (Holotype, BM; Isotypes, MANCH, PC); extant species.

$\equiv$ Mastigolejeunea auriculata (Wilson \& Hook.) Stephani (1892: 171).

Additional fossil specimen: MB.Pb.1984-1075.

Reference: Gradstein (1993), fig. 7 as Mastigolejeunea auriculata.

Age and stratigraphic level: 15-20 Ma, Langhian-Burdigalian (early to middle Miocene), La Toca Formation, Dominican Republic.

Calibration: Minimum age of the extant species Thysananthus auriculatus.

Justification: The fossil specimen is preserved with androecia as well as gynoecia and mature perianth on separate shoots, therefore it might be dioicous (Gradstein 1993). This allows a detailed comparison with extant representatives of the species which belongs to subgen. Mastigolejeunea sect. Mastigolejeunea. The specimen is characterized by elongated, distinctly convex-concave leaves with rounded apices, large, 1-toothed lobules with very oblique distal ends, elongated leaf cells with cordate trigones, obdeltoid underleaves with truncate apices, male bracts (4-6 pairs) with large, hypostatic lobules, gynoecia with single, repeatedly fertile innovations with lejeuneoid leaf sequences, densely imbricate, broadly oblong female bracts and bracteoles with rounded apices and entire margins, and immersed, sharply and smoothly trigonous perianths with a short beak and a very narrow ventral perianth keel which is as wide as the lateral keels.

\section{Thysananthus contortus (Göpp. \& Berendt) Sukkharak \& Gradstein (2017: 103)}

Basionym: Jungermannites contortus Göpp. \& Berendt in Göppert (1845: 114).—Holotype: MB.Pb.1979/479 (Coll. Berendt), Baltic amber.

$\equiv$ Phragmicoma contorta (Göpp. \& Berendt) Caspary (1887: 2).

$\equiv$ Trocholejeunea contorta (Göpp. \& Berendt) Gradst. \& Grolle in Grolle (1982: 178).

$\equiv$ Mastigolejeunea contorta (Göpp. \& Berendt) Gradst. \& Grolle in Grolle et al. (2004: 119).

= Phragmicoma magnistipulata Caspary (1887: 2).—Holotype: MB.Pb.1979/714 (Coll. Künow 171), Baltic amber.—Syn. fide Grolle (1982).

= Phragmicoma suborbiculata Caspary (1887: 2).-Holotype: MB.Pb.1979/470 (Coll. Berendt), Baltic amber.-Syn. fide Grolle (1982).

= Phragmicoma suborbiculata var. sinuata Caspary (1887: 2).—Holotype: MB.Pb.1979/713 (Coll. Künow 170), Baltic amber.—Syn. fide Grolle (1982).

= Lejeunea alifera Casp. in Caspary \& Klebs (1907: 29).-Holotype: destroyed (“Amber collection of the Physikalisch-Ökonomische Gesellschaft at the former Königsberg” 134 ).- -Syn. fide Grolle et al. (2004).

= Lejeunea serpyllifolia sensu Göppert [non Libert] (1853: 456). - Syn. fide Caspary (1887).

= Radula complanata sensu Göppert [non (L.) Dumort.] (1853: 456). - Syn. fide Caspary (1887).

= Trocholejeunea sandvicensis sensu Weis [non (Gottsche) Mizutani] (2001: 114). - Syn. fide Grolle et al. (2004).

Additional specimens: Baltic amber: GPIH 701, 2541a; GRÖHN 0154, 0908, 1557, 1540b, 2011, 2052a, 2061, 
2074, 2078 (det. Cheilolejeunea latiloba in Grolle \& Meister 2004b), 2084, 2086, 2098, 5838; WAR-MZ s.n. (Coll. Deptula 1807); VELTEN H0001a; WINTER 2897 (Coll. Gröhn). Bitterfeld amber: GZG.BST.22069 (Coll. Hoffeins 5-22), GZG.BST.22070 (Coll. Hoffeins 622-1), GZG.BST.22071 (Coll. Hoffeins 930-1), GZG.BST.22072 (Coll. Grabenhorst Le-29), GZG.BST.22073 (Coll. Grabenhorst Le-31), GZG.BST.22074 (Coll. Grabenhorst Le56), GZG.BST.22075 (Coll. Grabenhorst Le-60), GZG.BST.22076 (Coll. Grabenhorst Le-65), GZG.BST.22077 (Coll. Grabenhorst Le-67), GZG.BST.22078 (Coll. Grabenhorst Le-85), GZG.BST.22044 (Coll. Grabenhorst Le-117); MB.Pb.sn (Coll. Kutscher Ku-98H01), MB.Pb.sn (Coll. Kutscher Ku-98H02a), MB.Pb.sn (Coll. Kutscher Ku-98H08), MB.Pb.sn (Coll. Kutscher Ku-98H11a), MB.Pb.1996/1342a (Coll. Kutscher), MB.Pb.1997/15 (ser. 8/5a), MB.Pb.1997/26 (Coll. Grolle M-11/2).

References: Göppert (1845), Tafel VI Figs. 40, 41 as Jungermannites contortus; Caspary (1887), Tafel I Bild 6 as Phragmicoma contorta, Tafel I Bild 5 as P. magnistipulata, Tafel I Bild 7 as P. suborbiculata, Tafel I Bild 8 as $P$. suborbiculata var. sinuata; Caspary \& Klebs (1907), Tafel II Bild 16, 16a-c as P. contorta, Tafel II Bild 15, 15a-c as P. magnistipulata, Tafel II Bild 17, 17a-c as P. suborbiculata, Tafel II Bild 18, 18a-c as P. suborbiculata var. sinuata, Tafel III Bild 24, 24a-c as Lejeunea alifera; Grolle (1982), fig. 1a, b, tables 1-7 as Trocholejeunea contorta; Grolle (1985c), fig. 2a, b as Lejeunea alifera, fig. 2c as Trocholejeunea contorta; Grolle (1989), Abb. 1c, d as Trocholejeunea contorta; Grolle et al. (2004), figs. 1, 2 as Mastigolejeunea contorta; Grolle \& Meister (2004b), plates 14, 15 as Mastigolejeunea contorta; Heinrichs et al. (2018a), plate VI(4, 5) as Mastigolejeunea contorta.

Age and stratigraphic level: 34-41 Ma, Priabonian-Bartonian (Eocene), Baltic region; and $24 \mathrm{Ma}$, Chattian (late Oligocene), Bernsteinschluff Horizon in the upper part of the Cottbus Formation of the Goitzsche mine, Bitterfeld, Germany.

Calibration: Minimum age of Thysananthus.

Justification: Thysananthus contortus is known with gynoecia and perianth. The entire margined female involucre and the underleaves, which are not adnate to the lateral leaves, suggest affinities to subgen. Mastigolejeunea, but there are exceptions concerning both characters (Sukkharak \& Gradstein 2014, 2017). The fossil has been employed as age constraint for Mastigolejeunea in several divergence time estimates (Heinrichs et al. 2007, Wilson et al. 2007, Cooper et al. 2012, Feldberg et al. 2014, Laenen et al. 2014, Sun et al. 2014) but due to the current taxonomy, it should better be assigned to Thysananthus s.l.

\section{Family: Porellaceae Cavers}

\section{Genus: Porella Linnaeus (1753: 1106)}

\section{Porella subgrandiloba Grolle \& So (2004: 485)}

Holotype: GPIH 4328 (Coll. Gröhn 2096).

References: Grolle \& So (2004), figs. 1-4; Grolle \& Meister (2004b), plate 20 a-d.

Age and stratigraphic level: 34-41 Ma, Priabonian-Bartonian (Eocene), Baltic region.

Calibration: Minimum age of Porella.

Justification: The generic assignment of the sterile fossil is reliable but the affinity to extant species is uncertain (Grolle \& So 2004). Porella subgrandiloba lacks mature perianths and basal appendages. It is small in relation to extant species and might represent a detached branch. The morphologically most similar extant species are the much larger P. grandiloba Lindberg (1872: 234) and P. obtusata (Taylor 1846: 380) Trevisan (1877: 407) var. macroloba (Stephani 1910: 292) Hattori \& Zhang (1985: 325). It has been employed as an age constraint in Laenen et al. (2014) who estimated median ages of 34.27-47.33 Ma for Porella, and in Feldberg et al. (2014) who estimated a mean age of $39.65 \mathrm{Ma}$.

\section{Family: Radulaceae Müll.Frib.}

\section{Genus: Radula Dumortier (1822: 112)}

This subcosmopolitan genus includes ca. 200 extant species (in seven subgenera), two extinct species from Cretaceous Burmese amber, and five extinct species from Cenozoic ambers (e.g., Heinrichs et al. 2016b, 2018a, Söderström et al. 2016, Kaasalainen et al. 2017). The center of diversity is in humid, tropical to warm temperate regions, and the majority of species are epiphytes or epiphylls. Integrative taxonomy based on extensive molecular phylogenetic 
datasets and morphological studies has extended the knowledge on species delimitations (e.g., Devos et al. 2011, Renner et al. 2013a, b, Renner 2014, 2015, Patiño et al. 2017), but Radula remains taxonomically challenging. Species exhibit complex patterns of variation which tend to obscure species boundaries, and morphological homoplasy in critical taxonomic characters, including lobule shape, appears to be common (Renner et al. 2013a, Renner 2015). Morphologically similar plants may belong to different main lineages (Devos et al. 2011, Renner 2015), a feature that makes confident placement of fossils difficult.

The Cretaceous species provide the oldest ages for subgenera of Radula, and R. cretacea Bechteler, M.A.M.Renner, Schäf.-Verw. \& Heinrichs in Bechteler et al. (2017b: 206) has already been employed as constraint (Fig. 10A).

The additional use of the much younger Cenozoic species as constraints would therefore require thorough morphological studies to assign them to corresponding lineages, though this might not be possible with the sterile material. Species from Baltic amber are R. baltica Heinrichs, Schäf.-Verw. \& M.A.M.Renner in Heinrichs et al. (2016b: 158) which is only known from the sterile holotype, the autoecious $R$. oblongifolia Caspary (1887: 4) which also occurs in Bitterfeld amber and is preserved with androecia, gynoecia, and sporophyte (Fig. 10B), as well as $R$. sphaerocarpoides which is also know from several inclusions but only in sterile condition (Fig. 10C). What complicates the assignment of the latter two species is the morphologically heterogenous fossil material. It is possible that these species represent more than two biological entities (Heinrichs et al. 2016b). The youngest fossil is R. intecta M.A.M.Renner, Schäf.-Verw. \& Heinrichs in Kaasalainen et al. (2017: 324) from Miocene Dominican amber which is sterile and cannot be assigned to a subgenus with confidence.

The presence of Radula in Baltic amber has provided age constraints for Heinrichs et al. (2007), Feldberg et al. (2014), and Laenen et al. (2014). Feldberg et al. (2014) estimated a mean age of 119.53 Ma for the crown group and Laenen et al. (2014) median ages of 97.34-122.44 Ma. These ages are significantly younger than those of Bechteler et al. (2017b) who estimated a mean age of 183.8 Ma with standard substitution rates as calibration and 176.3 Ma by assigning $R$. cretacea to the stem of subgen. Odontoradula Yamada (1979: 209).

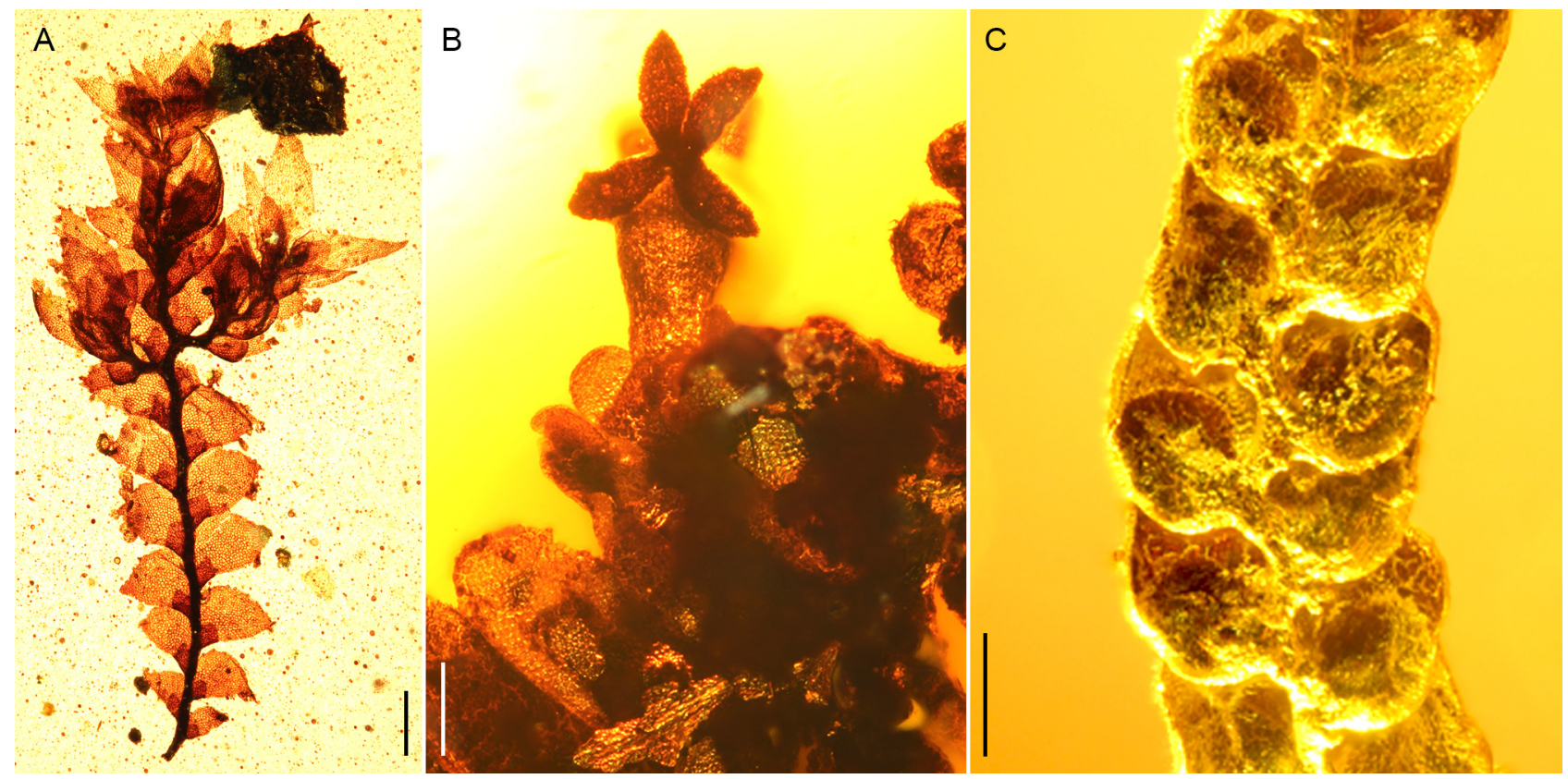

FIGURE 10. Radulaceae. A. Radula cretacea, PB22484 (holotype) in ventral view with gynoecia. B. Radula oblongifolia, MB.Pb.1997/1 from Bitterfeld amber with perianth and capsule. C. Radula sphaerocarpoides, GRÖHN 5815 from Baltic amber in ventral view. Scale bars: $\mathrm{A}=500 \mu \mathrm{m}, \mathrm{B}, \mathrm{C}=200 \mu \mathrm{m}$.

\section{Radula subgenus: Odontoradula}

\section{Radula cretacea; Fig. 10A}

Holotype: PB22484.

References: Bechteler et al. (2017b), fig. 1; Heinrichs et al. (2018a), plate V(1, 2); Feldberg et al. (2021), fig. 1H. Age and stratigraphic level: $99 \mathrm{Ma}$, late Albian-early Cenomanian (Late Cretaceous), amber mines southwest of the village of Tanai ca. $105 \mathrm{~km}$ north of Myitkyina in Kachin State, northern Myanmar (Burmese amber).

Calibration: Stem of Radula subgen. Odontoradula. 
Justification: The fossil is characterized by spreading lateral leaves with acute to acuminate dorsal lobes and small quadrate to trapeziform lobules as well as gynoecia with two bract pairs terminal on the leading axis and on short branches (Fig. 10A; Bechteler et al. 2017b). These characters are in good accordance with the extant representatives of subgen. Odontoradula sect. Acutifoliae Castle ex Grolle (1970: 666) ser. Acutifoliae Yamada (1979: 214). Bechteler et al. (2017b) thoroughly evaluated the assignment of the fossil by comparing divergence time estimates obtained by calibrating different nodes of the phylogeny. An assignment within the crown group to sect. Acutifoliae ser. Acutifoliae led to unrealistically old estimates that exceeded most estimates for land plants (e.g., Magallón et al. 2013), whereas an assignment of the fossil to the stem of subgen. Odontoradula led to age estimates in good accordance with analyses based on standard substitution rates (Patiño et al. 2017) as well as other age estimates for liverworts (Heinrichs et al. 2007, Cooper et al. 2012, Feldberg et al. 2014, Laenen et al. 2014) and provides evidence for a late Cretaceous origin of most subgenera and a Paleogene diversification of crown groups.

\section{Radula subgenus: Amentuloradula Devos, Renner, Gradstein, Shaw \& Vanderpoorten (2011: 1630)}

\section{Radula heinrichsii K.Feldberg, Schäf.-Verw., M.A.M.Renner, von Konrat \& A.R.Schmidt in Feldberg et al. (2021)}

Holotype: GZG.BST.22023 (Coll. Müller BuB3683).

Reference: Feldberg et al. (2021), figs. 1.I, 7.

Age and stratigraphic level: $99 \mathrm{Ma}$, late Albian-early Cenomanian (Late Cretaceous), amber mines southwest of the village of Tanai ca. $105 \mathrm{~km}$ north of Myitkyina in Kachin State, northern Myanmar (Burmese amber).

Calibration: Possible minimum age for stem of Radula subgen. Amentuloradula.

Justification: The sterile fossil is characterized by longitudinally inserted ventral lobules and the presence of Radulatype microphyllous branches. Among extant species this combination of characters only occurs in the Asian and Australasian subgen. Amentuloradula. However, there are also some differences to extant representatives of the subgenus. The microphyllous leaf lobes and lobules are more inflated and widely spaced than is typical of amentulose branches, and their stature relative to the primary shoot is generally smaller than typical microphyllous axes found in extant species (Feldberg et al. 2021). In these characteristics they bear some resemblance to the microphyllous/ amentulose axes borne by R. brunnea Stephani (1910: 232) of subgen Dactyloradula Devos, Renner, Gradstein, Shaw \& Vanderpoorten (2011: 1630) which represents an ancient lineage sister to all Radula species bar the isolated subgen. Cladoradula Spruce (1885: 315) (Devos et al. 2011). Unlike R. brunnea though, $R$. heinrichsii has a longitudinal lobule insertion. The species probably has mammillae on its dorsal leaf surface which would be unusual for subgen. Amentuloradula. Mammillose leaf cells on the main shoot are not very common in this subgenus and only occur in $R$. ornata Brown \& Pócs (2001: 436) while they are restricted to the amentulose branches in other species. Furthermore, the shape of the leaf lobes is rectangular-reniform instead of rounded and the trigones are small instead of large. These characters are somewhat inconsistent with the circumscription of subgen. Amentuloradula (leaves rounded, cells smooth, with large trigones) as given by Devos et al. (2011), but this circumscription has been pending revision since Patiño et al. (2017) demonstrated that morphologically disparate species such as $R$. marginata Gottsche, Lindenberg \& Nees (1845a: 261) and R. patens Yamada (1984: 197) also belonged to the subg. Amentuloradula lineage. That this somewhat unusual combination of characters occurred in stem-lineage Radula species now extinct can therefore not be discounted on present knowledge. This is supported by Patiño et al. (2017) who estimated an Eocene age for the crown group of subgen. Amentuloradula. The use as age constraint should include a thorough cross evaluation of the fossil assignment as has been done for $R$. cretacea (Bechteler et al. 2017b).

\section{Order: Ptilidiales Schljakov}

\section{Family: Ptilidiaceae H.Klinggr}

\section{Genus: Ptilidium Nees (1833b: 95)}

A fossil of this genus from Baltic amber was described as the extant Ptilidium pulcherrimum (Weber 1778: 150) Vainio (1878: 88) in Grolle \& Meister (2004b), but a recent divergence time estimation calibrated with standard substitution rates conflicts with the status of the fossil as an extant species, because the results indicate a Miocene origin of $P$. 
pulcherrimum (Heinrichs et al. 2015b). Furthermore, the fossil shows significant morphological differences to extant P. pulcherrimum, which also supports the assumption that it is an extinct rather than an extant species. Unfortunately, the specimen SMNS-BB2379 seems to be lost and morphological comparisons had to depend on the photos published in Grolle \& Meister (2014b, plate 21), therefore Heinrichs et al. (2015b) did not describe a new species. The fossil was employed as minimum age constraint in Feldberg et al. (2014) who estimated a mean age of $93.75 \mathrm{Ma}$ for the stem of the genus and by Laenen et al. (2014) who estimated median ages of 34.5-55.87 Ma for Ptilidium. Based on substitution rates Heinrichs et al. (2015b) estimated mean ages of 114.15 Ma for the stem and 33.71 Ma for the crown.

\section{Acknowledgments}

We would like to thank Heinrich Grabenhorst (Wienhausen), Christel and Hans Werner Hoffeins (Hamburg), Patrick Müller (Zweibrücken), Gerhard Winter (Karben), and Jörg Wunderlich (Hirschberg an der Bergstraße) for providing specimens for study. We thank Alexander Gehler (Göttingen) and Christian Neumann (Berlin) for access to the amber collections of the Geoscience Centre at the University of Göttingen and the Museum für Naturkunde zu Berlin and for granting preparation permissions. Mónica M. Solórzano-Kraemer (Frankfurt am Main) kindly shared information regarding the current dating of Dominican and Mexican amber. Financial support from the German Research Foundation (DFG, project 428174246 to K.F.) is gratefully acknowledged.

\section{References}

Arcila, D., Pyron, R.A., Tyler, J.C., Ortí, G. \& Betancur, R.R. (2015) An evaluation of fossil tip-dating versus node-age calibrations in tetraodontiform fishes (Teleostei: Percomorphaceae). Molecular Phylogenetics and Evolution 82: 131-145. https://doi.org/10.1016/j.ympev.2014.10.011

Ahonen, I. (2006) The taxonomic position of the genus Nipponolejeunea Hatt. Journal of the Hattori Botanical Laboratory 99: 319342 .

Amakawa, T. (1960) Family Jungermanniaceae of Japan, II. Journal of the Hattori Botanical Laboratory 22: 1-90.

Anderson, H.M. (1976) A review of the Bryophyta from the Upper Triassic Molteno Formation, Karroo Basin, South Africa. Palaeontologia Africana 19: 21-30.

Aranda, S.C., Gradstein, S.R., Patiño, J., Laenen, B., Désamoré, A. \& Vanderpoorten, A. (2014) Phylogeny, classification and species delimitation in the liverwort genus Odontoschisma (Cephaloziaceae). Taxon 63: 1008-1025.

https://doi.org/10.12705/635.12

Arnell, H.W. (1902) Novae species generis Kantiae. Revue Bryologique 29: 26-32.

Arnell, S.W. (1962) Contribution to the knowledge of the hepaticae of Ecuador. Svensk Botanisk Tidskrift 56: 334-350.

Atwood, J.J. \& Mamontov, Y.S. (2020) Notes on Frullania chilcootiensis (Frullaniaceae, Marchantiophyta) with a new synonym, lectotypification and an expanded distribution. Botanica Pacifica 9: 191-195. https://doi.org/10.17581/bp.2020.09212

Austin, C.F. (1876) Notes on hepaticology. Botanical Bulletin. Hanover 1: 35-36. https://doi.org/10.1086/botabull.1.8.2995130

Bakalin, V.A. (2005) Monograficheskaia obrabotka roda Lophozia (Dumort.) Dumort. s. str. [Monograph of the genus Lophozia (Dumort.) Dumort. s. str.]. Nauka, Moscow, 240 pp.

Bakalin, V.A. (2016) A revision of Lepidoziaceae (Hepaticae) in the Russian Far East I. Bazzania. Botanica Pacifica 5: 33-52. https://doi.org/10.17581/bp.2016.05108

Bakalin, V.A. \& Vilnet, A.A. (2019) Lophozia fuscovirens sp. nov. (Lophoziaceae, Marchantiophyta): the second taxon with brown gemmae within Lophozia s.s. Nordic Journal of Botany 37: e02294. https://doi.org/10.1111/njb.02294

Barba-Montoya, J., dos Reis, M. \& Yang, Z. (2017) Comparison of different strategies for using fossil calibrations to generate the time prior in Bayesian molecular clock dating. Molecular Phylogenetics and Evolution 114: 386-400. https://doi.org/10.1016/j.ympev.2017.07.005

Barthel, M. \& Hetzer, H. (1982) Bernstein-Inklusen aus dem Miozän des Bitterfelder Raumes. Zeitschrift für Angewandte Geologie 28: 314-336. 
Bastos C.J.P. \& Gradstein S.R. (2020) The genus Cheilolejeunea (Marchantiophyta: Lejeuneaceae) in tropical America. Nova Hedwigia 111: $287-335$.

https://doi.org/10.1127/nova_hedwigia/2020/0596

Beavan, A.J.S., Donoghue, P.C.J., Beaumont, M.A. \& Pisani, D. (2020) Performance of a priori and a posteriori calibration strategies in divergence time estimation. Genome Biology and Evolution 12: 1087-1098.

https://doi.org/10.1093/gbe/evaa105

Bechteler, J., Lee, G.E., Schäfer-Verwimp, A., Pócs, T., Peralta, D.F., Renner, M.A.M., Schneider, H. \& Heinrichs, J. (2016) Towards a monophyletic classification of Lejeuneaceae IV: reinstatement of Allorgella, transfer of Microlejeunea aphanella to Vitalianthus and refinements of the subtribal classification. Plant Systematics and Evolution 302: 187-201.

https://doi.org/10.1007/s00606-015-1252-8

Bechteler, J., Schäfer-Verwimp, A., Lee, G.E., Feldberg, K., Pérez-Escobar, O.A., Pócs, T., Peralta, D.F., Renner, M.A.M. \& Heinrichs, J. (2017a) Geographical structure, narrow species ranges, and Cenozoic diversification in a pantropical clade of epiphyllous leafy liverworts. Ecology and Evolution 7: 638-653.

https://doi.org/10.1002/ece3.2656

Bechteler, J., Schmidt, A.R., Renner, M.A.M., Wang, B., Pérez-Escobar, O.A., Schäfer-Verwimp, A., Feldberg, K. \& Heinrichs, J. (2017b) A Burmese amber fossil of Radula (Porellales, Jungermanniopsida) provides insights into the Cretaceous evolution of epiphytic lineages of leafy liverworts. Fossil Record 20: 201-213.

https://doi.org/10.5194/fr-20-201-2017

Berry, E.W. (1919) Upper Cretaceous floras of the eastern Gulf region in Tennessee, Mississippi, Alabama, and Georgia. United States Geological Survey, Professional Paper 112: 1-177. https://doi.org/10.3133/pp112

Bischler, H., Bonner, C.E.B. \& Miller, H.A. (1963) Studies in Lejeuneaceae VI. The genus Microlejeunea Steph. in Central and South America. Nova Hedwigia 5: 359-411 (plates 59-70).

Bouckaert, R., Heled, J., Kühnert, D., Vaughan, T., Wu, C.-H., Xi, D., Suchard, M.A., Rambaut, A. \& Drummond, A.J. (2014) BEAST 2: a software platform for Bayesian evolutionary analysis. PloS Computational Biology 10: e1003537. https://doi.org/10.1371/journal.pcbi.1003537

Braggins, J.E., Renner, M.A.M. \& de Lange, P.J. (2014) Additions to the liverwort flora of the Kermadec Islands, New Zealand Botanical Region. Telopea 17: 183-194. https://doi.org/10.7751/telopea20147709

Bromham, L., Duchêne, S., Hua, X., Ritchie, A.M., Duchêne, D.A. \& Ho, S.Y.W. (2018) Bayesian molecular dating: opening up the black box. Biological Reviews 93: 1165-1191.

https://doi.org/10.1111/brv.12390

Brongniart, A.T. (1849) Végétaux fossiles. In: D’Orbigny, C. (Ed.) Dictionnaire universel d'histoire naturelle. Tome treiziéme. Mm. Renard, Martinet et C., Paris, pp. 52-173.

Brown, E.A. \& Pócs, T. (2001) A new species of Radula sect. Cavifolium (Radulaceae: Hepaticae) from Queensland, Australia. Telopea 9: 435-438. https://doi.org/10.7751/telopea20024000

Brown, J.T. \& Robison, C.R. (1974) Diettertia montanensis, gen. et sp. nov., a fossil moss from the Lower Cretaceous Kootenai Formation of Montana. Botanical Gazette 135: 170-173. https://doi.org/10.1086/336747

Buch, H. (1928) Die Scapanien Nordeuropas und Sibiriens. II. Systematischer Teil. Societas Scientiarum Fennica. Commentationes Biologicae 3: 1-177.

Buch, H. (1932) Vorarbeiten zu einer Lebermoosflora Fenno-scandias. I. Ein Versuch zur Aufspaltung der Gattungen Lophozia Dum. und Sphenolobus Steph. Memoranda Societatis pro Fauna et Flora Fennica 8: 282-297.

Buch, H. \& Persson, H. (1941) Bryophyten von den Azoren und Madeira. Akademische Buchhandlung, Helsingfors, 16 pp.

Buczkowska, K., Bakalin, V., Bączkiewicz, A., Aguero, B., Gonera, P., Ślipiko, M., Szczecińska, M. \& Sawicki, J. (2018) Does Calypogeia azurea (Calypogeiaceae, Marchantiophyta) occur outside Europe? Molecular and morphological evidence. PloS ONE 13: e0204561. https://doi.org/10.1371/journal.pone.0204561

Carruthers, T. \& Scotland, R.W. (2020) Insights from empirical analyses and simulations on using multiple fossil calibrations with relaxed clocks to estimate divergence times. Molecular Biology and Evolution 37: 1508-1529. https://doi.org/10.1093/molbev/msz310

Carter, B.E., Larraín, J., Manukjanová, A., Shaw, B., Shaw, A.J., Heinrichs, J., de Lange, P., Suleiman, M., Thouvenot, L. \& von Konrat, M. (2017) Species delimitation and biogeography of a southern hemisphere liverwort clade, Frullania subgenus Microfrullania 
(Frullaniaceae, Marchantiophyta). Molecular Phylogenetics and Evolution 107: 16-26.

https://doi.org/10.1016/j.ympev.2016.10.002

Caspary, R. (1887) Einige neue Pflanzenreste aus dem samländischen Bernstein. Schriften der Physikalisch-Ökonomischen Gesellschaft zu Königsberg (Abhandlungen) 27: 1-8 [209]. Tafel I. „1886“.

Caspary, R. \& Klebs, R. (1907) Die Flora des Bernsteins und anderer fossiler Harze des ostpreußischen Tertiärs. Abhandlungen der Königlich Preussischen Geologischen Landesanstalt, N. F. 4: 1-182. Text + Atlas.

Cheah, Y.-H. \& Yong, K.-T. (2016) New records of Bazzania species (Marchantiophyta: Lepidoziaceae) in peninsula Malaysia with identification key. Cryptogamie, Bryologie 37: 199-210. https://doi.org/10.7872/cryb/v37.iss2.2016.199

Choi, S.S., Bakalin, V.A. \& Sun, B.-Y. (2012) Scapania and Macrodiplophyllum in the Russian Far East. Botanica Pacifica 1: 31-95. https://doi.org/10.17581/bp.2012.01104

Cooper, E.D., Henwood, M.J. \& Brown, E.A. (2012) Are the liverworts really that old? Cretaceous origins and Cenozoic diversifications in Lepidoziaceae reflect a recurrent theme in liverwort evolution. Biological Journal of the Linnean Society 107: 425-441. https://doi.org/10.1111/j.1095-8312.2012.01946.x

Crandall-Stotler, B., Stotler, R.E. \& Long, D.G. (2009) Phylogeny and classification of the Marchantiophyta. Edinburgh Journal of Botany 66: $155-198$.

https://doi.org/10.1017/S0960428609005393

Dauphin, G. (2003) Ceratolejeunea. Flora Neotropica Monograph 90: 1-86.

De Roo, R.T., Hedderson, T.A. \& Söderström, L. (2007) Molecular insights into the phylogeny of the leafy liverwort family Lophoziaceae Cavers. Taxon 56: 301-314. https://doi.org/10.1002/tax.562005

Devos, N., Renner, M.A.M., Gradstein, S.R., Shaw, J. \& Vanderpoorten, A. (2011) Molecular data challenge traditional subgeneric divisions in the leafy liverwort Radula. Taxon 60: 1623-1632. https://doi.org/10.1002/tax.606007

Dickson, J. (1793) Fasciculus tertius plantarum cryptogamicarum britanniae. G. Nichol, London, 24 pp.

Didier, G. \& Laurin, M. (2020) Exact distribution of divergence times from fossil ages and tree topologies. Systematic Biology 69: 1068-1087. https://doi.org/10.1093/sysbio/syaa021

Dixon, H.N., Schiffner, V. \& Verdoorn, F. (1932) Bryophyta nova (1-5). Annales Bryologici 5: 159-164.

Dong, S., Schäfer-Verwimp, A., Meinecke, P., Feldberg, K., Bombosch, A., Pócs, T., Schmidt, A.R., Reitner, J., Schneider, H. \& Heinrichs, J. (2012) Tramps, narrow endemics and morphologically cryptic species in the epiphyllous liverwort Diplasiolejeunea. Molecular Phylogenetics and Evolution 65: 582-594.

https://doi.org/10.1016/j.ympev.2012.07.009

Dong, S., Schäfer-Verwimp, A., Pócs, T., Feldberg, K., Czumaj, A., Schmidt, A.R., Schneider, H. \& Heinrichs, J. (2013) Size doesn’t matter-recircumscription of Microlejeunea (Lejeuneaceae, Porellales) based on molecular and morphological evidence. Phytotaxa 85 (2): 41-55.

https://doi.org/10.11646/phytotaxa.85.2.2

Douin, C. (1920) La famille des Céphaloziellacées. Mémoires de la Société Botanique de France 29: 1-90. https://doi.org/10.1080/00378941.1916.10839749

Drummond, A.J. \& Bouckaert, R.R. (2015) Bayesian evolutionary analysis with BEAST. Cambridge University Press, Cambridge, 260 pp.

https://doi.org/10.1017/CBO9781139095112

Dumortier, B.C.J. (1822) Commentationes botanicae. Ch. Casterman-Dieu, Tournay, 117 pp. https://doi.org/10.5962/bhl.title.10534

Dumortier, B.C.J. (1835) Recueil d'Observations sur les Jungermanniacées. I. Révision des genres. J.-A. Blanquart, Tournay, 27 pp. https://doi.org/10.5962/bhl.title.731

Dunlop, J.A. (2010) Bitterfeld amber. In: Penney, D. (Ed.) Biodiversity of fossils in amber from the major world deposits. Siri Scientific Press, Manchester, pp. 57-68.

Edwards, D., Morris, J.L., Richardson, J.B. \& Kenrick, P. (2014) Cryptospores and cryptophytes reveal hidden diversity in early land floras. New Phytologist 202: 50-78. https://doi.org/10.1111/nph.12645

Evans, A.W. (1904) Hepaticae of Puerto Rico. IV. Odontolejeunea, Cyclolejeunea and Prionolejeunea. Bulletin of the Torrey Botanical Club 31: 183-226. https://doi.org/10.2307/2478687 
Evans, A.W. (1907) Hepaticae of Puerto Rico. VII. Stictolejeunea, Neurolejeunea, Omphalanthus, and Lopholejeunea. Bulletin of the Torrey Botanical Club 34: 1-34. https://doi.org/10.2307/2479163

Feldberg, K., Heinrichs, J., Schmidt, A.R., Váňa, J. \& Schneider, H. (2013) Exploring the impact of fossil constraints on the divergence time estimates of derived liverworts. Plant Systematics and Evolution 299: 585-601. https://doi.org/10.1007/s00606-012-0745-y

Feldberg, K., Schneider, H., Stadler, T., Schäfer-Verwimp, A., Schmidt, A.R. \& Heinrichs, J. (2014) Epiphytic leafy liverworts diversified in angiosperm-dominated forests. Scientific Reports 4: 5974. https://doi.org/10.1038/srep05974

Feldberg, K., Váňa, J., Krusche, J., Kretschmann, J., Patzak, S.D.F., Pérez-Escobar, O.A., Rudolf, N.R., Seefelder, N., Schäfer-Verwimp, A., Long, D.G., Schneider, H. \& Heinrichs, J. (2016) A phylogeny of Cephaloziaceae (Jungermanniopsida) based on nuclear and chloroplast DNA markers. Organisms Diversity and Evolution 16: 727-742. https://doi.org/10.1007/s13127-016-0284-4

Feldberg, K., Váňa, J., Schäfer-Verwimp, A., Krings, M., Gröhn, C., Schmidt, A.R. \& Heinrichs, J. (2017) Problems related to the taxonomic placement of incompletely preserved amber fossils: transfer of the Paleogene liverwort Cylindrocolea dimorpha (Cephaloziellaceae) to the extant Odontoschisma sect. Iwatsukia (Cephaloziaceae). Fossil Record 20: 147-157. https://doi.org/10.5194/fr-20-147-2017

Feldberg, K., Müller, A.S., Schäfer-Verwimp, A., von Konrat, M., Schmidt, A.R. \& Heinrichs, J. (2018) Frullania grabenhorstii sp. nov., a fossil liverwort (Jungermanniopsida: Frullaniaceae) with perianth from Bitterfeld amber. Bryophyte Diversity and Evolution 40: 91-103. https://doi.org/10.11646/bde.40.2.7

Feldberg, K., Schäfer-Verwimp, A., Renner, M.A.M., von Konrat, M., Bechteler, J., Müller, P., Wang, Y.-D., Schneider, H. \& Schmidt, A.R. (2021) Liverworts from Cretaceous amber. Cretaceous Research. [in press]

Frahm, J.-P. \& Gröhn, C. (2013) More fossil bryophytes from Baltic amber. Archive for Bryology 159: 1-9.

Godfrey, J.D. \& Godfrey, G.A. (1980) Frullania hattoriana, a new hepatic from British Columbia, Canada. Journal of the Hattori Botanical Laboratory 48: 321-327.

Göppert, H.R. (1845) Übersicht der bis jetzt bekannten in und mit dem Bernstein vorkommenden vegetabilischen Reste. In: Berendt, G.C. (Ed.) Die im Bernstein befindlichen organischen Reste der Vorwelt. Erster Band. I. Abteilung. Nicolaische Buchhandlung, Berlin, pp. 69-125. https://doi.org/10.5962/bhl.title.66910

Göppert, H.R. (1853) Über die Bernsteinflora. Verhandlungen der Königlich-Preußischen Akademie der Wissenschaften zu Berlin 1853: $450-476$.

Gottsche, C.M. (1857) Pugillus novarum hepaticarum. Annales des Sciences Naturelles; Botanique (sér. 4) 8: 318-348.

Gottsche, C.M. (1886) Über die im Bernstein eingeschlossenen Lebermoose. Botanisches Centralblatt 25: 95-97, 121-123.

Gottsche, C.M., Lindenberg, J.B.W. \& Nees, C.G. (1845a) Synopsis hepaticarum, fasc. 2. Meissner, Hamburg, pp. $145-304$. https://doi.org/10.5962/bhl.title.15221

Gottsche, C.M., Lindenberg, J.B.W. \& Nees, C.G. (1845b) Synopsis hepaticarum, fasc. 3. Meissner, Hamburg, pp. $305-464$. https://doi.org/10.5962/bhl.title.15221

Gradstein, S.R. (1975) A taxonomic monograph of the genus Acrolejeunea (Hepaticae). Bryophytorum Bibliotheca 4: 1-162.

Gradstein, S.R. (1993) New fossil Hepaticae preserved in amber of the Dominican Republic. Nova Hedwigia 57: 353-374.

Gradstein, S.R. (1994) Lejeuneaceae: Ptychantheae. Brachiolejeuneae. Flora Neotropica Monograph 62: 1-225.

Gradstein, S.R. (2012) An overview of the genus Marchesinia (Marchantiophyta: Lejeuneaceae), with special attention to the species described from Asia and Oceania. Polish Botanical Journal 57: 69-79.

Gradstein, S. R. (2013) A classification of Lejeuneaceae (Marchantiophyta) based on molecular and morphological evidence. Phytotaxa 100: 6-20. https://doi.org/10.11646/phytotaxa.100.1.2

Gradstein, S.R. (2017) Bazzania (Marchantiophyta) in South America. Nova Hedwigia 105: 243-266. https://doi.org/10.1127/nova_hedwigia/2017/0409

Gradstein, S.R. (2018) Amphi-Pacific tropical disjunctions in the bryophyte floras of Asia and the New World. Philippine Journal of Systematic Biology 12: 1-11. https://doi.org/10.26757/pjsb.2018a12012

Gradstein, S.R. (2020) The genera of Lejeuneaceae (Marchantiophyta) of tropical America-an update. Nova Hedwigia Beiheft 150: 8196.

https://doi.org/10.1127/nova-suppl/2020/081 
Gradstein, S.R. \& Ilkiu-Borges, A.L. (2015) A taxonomic revision of the genus Odontoschisma (Marchantiophyta: Cephaloziaceae). Nova Hedwigia 100: 15-100. https://doi.org/10.1127/nova_hedwigia/2014/0219

Gradstein, S.R., Churchill, S.P. \& Salazar-Allen, N. (2001) Guide to the bryophytes of tropical America. Memoirs of the New York Botanical Garden 86: 1-577.

Gradstein, S.R., Aranda, S.C. \& Vanderpoorten, A. (2014) Notes on Early Land Plants Today. 47. Transfer of Iwatsukia to Odontoschisma (Cephaloziaceae, Marchantiophyta). Phytotaxa 162 (4): 232-233.

https://doi.org/10.11646/phytotaxa.162.4.6

Gray, S.F. (1821) Natural arrangement of British plants. Vol. 1. Baldwin, Craddock, and Joy, London, 824 pp. https://doi.org/10.5962/bhl.title.43804

Grolle, R. (1970) Radula castlei sp. nov. und Anmerkungen zur Gattung Radula. The Bryologist 73: 662-668. https://doi.org/10.2307/3241278

Grolle, R. (1971) Hepaticopsida. In: Bakker, E.M.v.Z. Sr., Winterbottom, J.M. \& Dyer, R.A. (Eds.) Marion and Prince Edward Islands. Report on the South African Biological and Geological Expedition 1965-1966. Balkema, Cape Town, pp. 228-236.

Grolle, R. (1976) Verzeichnis der Lebermoose Europas und benachbarter Gebiete. Feddes Repertorium 87: 171-279. https://doi.org/10.1002/fedr.19760870303

Grolle, R. (1980a) Lebermoose im Bernstein 1. Feddes Repertorium 91: 183-190.

Grolle, R. (1980b) Lebermoose im Bernstein 2. Feddes Repertorium 91: 401-407.

Grolle, R. (1981a) Nipponolejeunea fossil in Europa. Journal of the Hattori Botanical Laboratory 50: 143-157.

Grolle, R. (1981b) Was ist Lejeunea schumannii Caspary aus dem Baltischen Bernstein? Occasional Papers of the Farlow Herbarium of Cryptogamic Botany 16: 101-110.

Grolle, R. (1982) Trocholejeunea fossil in Europa. Journal of the Hattori Botanical Laboratory 51: 175-193.

Grolle, R. (1983) Leucolejeunea antiqua n. sp., das erste Lebermoos aus Dominikanischem Bernstein. Stuttgarter Beiträge zur Naturkunde, Serie B 96: 1-9.

Grolle, R. (1984a) Bryopteris und Cyclolejeunea fossil in Dominikanischem Bernstein. Journal of the Hattori Botanical Laboratory 56: 271-280.

Grolle, R. (1984b) Cyrtolejeunea suzannensis spec. nov., ein weiteres fossiles Lebermoos in Dominikanischem Bernstein. Cryptogamie: Bryologie-Lichénologie 5: 27-32.

Grolle, R. (1984c) Die Lebermoosgattung Cheilolejeunea fossil in Mitteleuropa. Feddes Repertorium 95: 229-236.

Grolle, R. (1984d) Lejeunea palaeomexicana n. sp., das erste Moos aus Mexikanischem Bernstein. Stuttgarter Beiträge zur Naturkunde, Serie B 108: 1-7.

Grolle, R. (1985a) Zwei weitere Lebermoose in Bernstein aus Bitterfeld (DDR). Feddes Repertorium 96: 41-46.

Grolle, R. (1985b) Monograph of Frullania in Baltic amber. Prace Muzeum Ziemi 37: 87-100, pl. I-VI.

Grolle, R. (1985c) Fossil Spruceanthus in Europe and two other hepatics in Baltic amber. Prace Muzeum Ziemi 37: 79-85.

Grolle, R. (1988) Die Lebermoosgattung Notoscyphus fossil in Europa. Feddes Repertorium 99: 561-564 (Plates LXIV and LXV).

Grolle, R. (1989) Weitere Lebermoosfunde in Bitterfelder Bernstein, darunter Radula oblongifolia Caspary mit Sporophyt. Feddes Repertorium 100: 131-136.

Grolle, R. (1993a) Bryopteris bispinosa spec. nov. (Lejeuneaceae), ein weiteres Lebermoos in Dominikanischem Bernstein. Journal of the Hattori Botanical Laboratory 74: 71-76.

Grolle, R. (1993b) Ein autözisches Lebermoos mit Perianth in Dominikanischem Bernstein: Drepanolejeunea eogena spec. nov. Nova Hedwigia 57: 375-380.

Grolle, R. (1998) The Eocene hepatic Frullania baltica found with androecium, perianth and capsule. Nova Hedwigia 66: 451-456. https://doi.org/10.1127/nova.hedwigia/66/1998/451

Grolle, R. (1999) Metacalypogeia (Calypogeiaceae, Hepaticae) new to Europe as Baltic amber fossil. Bryobrothera 5: 87-91.

Grolle, R. (2003) Frullania mammilligera sp. nov., a new Eocene species of Hepaticae found in Bitterfeld Amber of central Germany. Courier Forschungs-Institut Senckenberg 241: 155-161.

Grolle, R. \& Braune, W. (1988) Bazzania oleosa, ein Lebermoos mit erhaltenen Ölkörpern in dominikanischem Bernstein. Beiheft zur Nova Hedwigia 90: 101-108.

Grolle, R. \& Heinrichs, J. (2003) Eocene Plagiochila groehnii sp. nov.-the first representative of Plagiochilaceae in Baltic amber. Cryptogamie, Bryologie 24: 289-293.

Grolle, R. \& Meister, K. (2004a) Lophozia kutscheri, a new hepatic (Jungermanniales) in Bitterfeld amber from Central Germany. The Bryologist 107: 79-81.

https://doi.org/10.1639/0007-2745(2004)107[79:LKANHJ]2.0.CO;2

Grolle, R. \& Meister, K. (2004b) The liverworts in Baltic and Bitterfeld amber. Weissdorn-Verlag, Jena, 91 pp. 
Grolle, R. \& Schmidt, A. (2001) A fossil Scapania (Hepaticae) with perianth and capsule in Bitterfeld amber (Eocene) from Germany. The Bryologist 104: 362-366.

https://doi.org/10.1639/0007-2745(2001)104[0362:AFSHWP]2.0.CO;2

Grolle, R. \& So, M.L. (2004) A fossil Porella (Porellaceae, Hepaticae) in Eocene Baltic amber. Botanical Journal of the Linnean Society 145: 485-488.

https://doi.org/10.1111/j.1095-8339.2004.00291.x

Grolle, R., Zhu, R.-L. \& Gradstein, S.R. (2001) On Cyrtolejeunea A.Evans (Lejeuneaceae, Hepaticae). Taxon 50: $1067-1074$. https://doi.org/10.2307/1224721

Grolle, R., Meister, K. \& So, M.L. (2004) New evidence on the taxonomic position of the Eocene Jungermannites contortus (Jungermanniales: Lejeuneaceae). Cryptogamie, Bryologie 25: 117-123.

Guindon, S. (2018) Accounting for calibration uncertainty: Bayesian molecular dating as a "doubly intractable" problem. Systematic Biology 67: 651-661. https://doi.org/10.1093/sysbio/syy003

Hartmann, F.A., Wilson, R., Gradstein, S.R., Schneider, H. \& Heinrichs, J. (2006) Testing hypotheses on species delimitations and disjunctions in the liverwort Bryopteris (Jungermanniopsida: Lejeuneaceae). International Journal of Plant Sciences 167: 12051214.

https://doi.org/10.1086/508023

Hattori, S. (1944) Contributio ad floram hepaticarum austro-kiushiuensem. Bulletin of the Tokyo Science Museum 11: 1-203.

Hattori, S. (1953) Notes on little known Japanese species of Hepaticae (3). Journal of Japanese Botany 28: 231-235.

Hattori, S. (1973) Notes on the Asiatic species of the genus Frullania, Hepaticae. III. Journal of the Hattori Botanical Laboratory 37 : $85-120$.

Hattori, S. (1974) Notes on the Asiatic species of the genus Frullania, Hepaticae. VI. Journal of the Hattori Botanical Laboratory 38: $223-274$.

Hattori, S. (1986) A synopsis of New Caledonian Frullaniaceae. Journal of the Hattori Botanical Laboratory 60: $203-237$.

Hattori, S. \& Zhang, M.-X. (1985) Porellaceae of Shensi Province, China. Journal of Japanese Botany 60: 321-326.

Heath, T.A., Huelsenbeck, J.P. \& Stadler, T. (2014) The fossilized birth-death process for coherent calibration of divergence-time estimates. Proceedings of the National Academy of Sciences of the United States of America 111: E2957-E2966. https://doi.org/10.1073/pnas.1319091111

Heinrichs, J. \& Schmidt, A.R. (2010) An inclusion of Frullania subgen. Diastaloba s. 1. (Frullaniaceae, Porellales) in Dominican amber. Tropical Bryology 31: 91-94. https://doi.org/10.11646/bde.31.1.15

Heinrichs, J., Hentschel, J., Wilson, R., Feldberg, K. \& Schneider, H. (2007) Evolution of leafy liverworts (Jungermanniidae, Marchantiophyta): estimating divergence times from chloroplast DNA sequences using penalized likelihood with integrated fossil evidence. Taxon 56: 31-44.

Heinrichs, J., Klugmann, F., Hentschel, J. \& Schneider, H. (2009) DNA taxonomy, cryptic speciation and diversification of the NeotropicalAfrican liverwort, Marchesinia brachiata (Lejeuneaceae, Porellales). Molecular Phylogenetics and Evolution 53: 113-121. https://doi.org/10.1016/j.ympev.2009.05.032

Heinrichs, J., Hentschel, J., Bombosch, A., Fiebig, A., Reise, J., Edelmann, M., Kreier, H.-P., Schäfer-Verwimp, A., Caspari, S., Schmidt, A.R., Zhu, R.-L., von Konrat, M., Shaw, B. \& Shaw, A.J. (2010). One species or at least eight? Delimitation and distribution of Frullania tamarisci (L.) Dumort. s. 1. (Jungermanniopsida, Porellales) inferred from nuclear and chloroplast DNA markers. Molecular Phylogenetics and Evolution 56: 1105-1114. https://doi.org/10.1016/j.ympev.2010.05.004

Heinrichs, J., Kreier, H.-P., Feldberg, K., Schmidt, A.R., Zhu, R.-L., Shaw, B., Shaw, A.J. \& Wissemann, V. (2011a) Formalizing morphologically cryptic biological entities: New insights from DNA taxonomy, hybridization, and biogeography in the leafy liverwort Porella platyphylla (Jungermanniopsida, Porellales). American Journal of Botany 98: 1252-1262. https://doi.org/10.3732/ajb.1100115

Heinrichs, J., Reiner-Drehwald, M.E., Feldberg, K., Grimaldi, D.A., Nascimbene, P.C., von Konrat, M. \& Schmidt, A.R. (2011b) Kaolakia borealis nov. gen. et sp. (Porellales, Jungermanniopsida): A leafy liverwort from the Cretaceous of Alaska. Review of Palaeobotany and Palynology 165: 235-240.

https://doi.org/10.1016/j.revpalbo.2011.04.002

Heinrichs, J., Bombosch, A., Feldberg, K., Kreier, H.-P., Hentschel, J., Eckstein, J., Long, D., Zhu, R.-L., Schäfer-Verwimp, A., Schmidt, A.R., Shaw, B., Shaw, A.J. \& Váňa, J. (2012a) A phylogeny of the northern temperate leafy liverwort genus Scapania (Scapaniaceae, Jungermanniales). Molecular Phylogenetics and Evolution 62: 973-985.

https://doi.org/10.1016/j.ympev.2011.11.029 
Heinrichs, J., Reiner-Drehwald, M.E., Feldberg, K., von Konrat, M., Hentschel, J., Váňa, J., Nascimbene, P., Grimaldi, D. \& Schmidt, A.R. (2012b) The leafy liverwort Frullania (Jungermanniopsida) in the Cretaceous amber forest of Myanmar. Review of Palaeobotany and Palynology 169: 21-28.

https://doi.org/10.1016/j.revpalbo.2011.10.002

Heinrichs, J., von Konrat, M., Grabenhorst, H. \& Schmidt, A.R. (2012c) The sporophyte of the Paleogene liverwort Frullania varians Caspary. Fossil Record 15: 115-120.

https://doi.org/10.1002/mmng.201200009

Heinrichs, J., Dong, S., Schäfer-Verwimp, A., Pócs, T., Feldberg, K., Czumaj, A., Schmidt, A.R., Reitner, J., Renner, M.A.M., Hentschel, J., Stech, M. \& Schneider, H. (2013) Molecular phylogeny of the leafy liverwort Lejeunea (Porellales): evidence for a Neotropical origin, uneven distribution of sexual systems and insufficient taxonomy. PloS ONE 8: e82547. https://doi.org/10.1371/journal.pone.0082547

Heinrichs, J., Schäfer-Verwimp, A., Boxberger, J., Feldberg, K., Solórzano Kraemer, M.M. \& Schmidt, A.R. (2014a) A fossil species of Ceratolejeunea (Lejeuneaceae, Porellales) preserved in Miocene Mexican amber. The Bryologist 117: 10-14. https://doi.org/10.1639/0007-2745-117.1.010

Heinrichs, J., Schäfer-Verwimp, A., Feldberg, K. \& Schmidt, A.R. (2014b) The extant liverwort Gackstroemia (Lepidolaenaceae, Porellales) in Cretaceous amber from Myanmar. Review of Palaeobotany and Palynology 203: 48-52. https://doi.org/10.1016/j.revpalbo.2014.01.004

Heinrichs, J., Kettunen, E., Lee, G.E., Marzaro, G., Pócs, T., Ragazzi, E., Renner, M.A.M., Rikkinen, J., Sass-Gyarmati, A., SchäferVerwimp, A., Scheben, A., Solórzano Kraemer, M.M., Svojtka, M. \& Schmidt, A.R. (2015a) Lejeuneaceae (Marchantiophyta) from a species-rich taphocoenosis in Miocene Mexican amber, with a review of liverworts fossilised in amber. Review of Palaeobotany and Palynology 221: 59-70. https://doi.org/10.1016/j.revpalbo.2015.05.007

Heinrichs, J., Scheben, A., Lee, G.E., Váňa, J., Schäfer-Verwimp, A., Krings, M. \& Schmidt, A.R. (2015b) Molecular and morphological evidence challenges the records of the extant liverwort Ptilidium pulcherrimum in Eocene Baltic amber. PloS ONE 10: e0140977. https://doi.org/10.1371/journal.pone.0140977

Heinrichs, J., Schmidt, A.R., Schäfer-Verwimp, A., Gröhn, C. \& Renner, M.A.M. (2015c) The leafy liverwort Notoscyphus balticus sp. nov. (Jungermanniales) in Eocene Baltic amber. Review of Palaeobotany and Palynology 217: 39-44. https://doi.org/10.1016/j.revpalbo.2015.02.006

Heinrichs, J., Scheben, A., Bechteler, J., Lee, G.E., Schäfer-Verwimp, A., Hedenäs, L., Singh, H., Pócs, T., Nascimbene, P.C., Peralta, D.F., Renner, M.A.M. \& Schmidt, A.R. (2016a) Crown group Lejeuneaceae and pleurocarpous mosses in early Eocene (Ypresian) Indian amber. PloS ONE 11: e0156301.

https://doi.org/10.1371/journal.pone.0156301

Heinrichs, J., Schmidt, A.R., Schäfer-Verwimp, A., Bauerschmidt, L., Neumann, C., Gröhn, C., Krings, M. \& Renner, M.A.M. (2016b) Revision of the leafy liverwort genus Radula (Porellales, Jungermanniopsida) in Baltic and Bitterfeld amber. Review of Palaeobotany and Palynology 235: 157-164.

https://doi.org/10.1016/j.revpalbo.2016.09.004

Heinrichs, J., Feldberg, K., Bechteler, J., Müller, P., Renner, M.A.M., Váňa, J., Schäfer-Verwimp, A. \& Schmidt, A.R. (2017a) A fossil genus of the Frullaniaceae (Porellales, Jungermanniopsida) from the mid-Cretaceous of Myanmar. Cretaceous Research 74: 223226. https://doi.org/10.1016/j.cretres.2017.02.023

Heinrichs, J., Feldberg, K., Müller, P., Schäfer-Verwimp, A., von Konrat, M., Ilsemann, B. \& Krings, M. (2017b) Frullania pinnata spec. nov. (Frullaniaceae, Porellales), a new leafy liverwort in mid-Cretaceous Burmese amber from Myanmar. Cretaceous Research 78: $56-60$.

https://doi.org/10.1016/j.cretres.2017.05.030

Heinrichs, J., Feldberg, K., Bechteler, J., Regalado, L., Renner, M.A.M., Schäfer-Verwimp, A., Gröhn, C., Müller, P., Schneider, H. \& Krings, M. (2018a) A comprehensive assessment of the fossil record of liverworts in amber. In: Krings, M., Cúneo, N.R., Harper, C.J. \& Rothwell, G.W. (eds.) Transformative Paleobotany. Papers to commemorate the life and legacy of Thomas N. Taylor. Elsevier/ Academic Press, New York, pp. 213-252. https://doi.org/10.1016/B978-0-12-813012-4.00012-7

Heinrichs, J., Schäfer-Verwimp, A., Renner, M.A.M. \& Feldberg, K. (2018b) Cheilolejeunea lamyi sp. nov., a fossil Lejeuneaceae from Miocene Dominican amber. Cryptogamie, Bryologie 39: 155-161. https://doi.org/10.7872/cryb/v39.iss2.2018.155

Hentschel, J., Paton, J.A., Schneider, H. \& Heinrichs, J. (2007) Acceptance of Liochlaena Nees and Solenostoma Mitt., the systematic position of Eremonotus Pearson and notes on Jungermannia L. s.l. (Jungermanniidae) based on chloroplast DNA sequence data. 
Plant Systematics and Evolution 268: 147-157.

https://doi.org/10.1007/s00606-007-0549-7

Hentschel, J., Schmidt, A.R. \& Heinrichs, J. (2009a) Frullania cretacea, sp. nov. (Porellales, Jungermanniopsida), a leafy liverwort preserved in Cretaceous amber from Myanmar. Cryptogamie, Bryologie 30: 323-328.

Hentschel, J., von Konrat, M.J., Pócs, T., Schäfer-Verwimp, A., Shaw, A.J., Schneider, H. \& Heinrichs, J. (2009b) Molecular insights into the phylogeny and subgeneric classification of Frullania Raddi (Frullaniaceae, Porellales). Molecular Phylogenetics and Evolution 52: 142-156.

https://doi.org/10.1016/j.ympev.2008.12.021

Hentschel, J., von Konrat, M., Söderström, L., Hagborg, A., Larraín, J., Sukkharak, P., Uribe, J. \& Zhang, L. (2015) Notes on Early Land Plants Today. 72. Infrageneric classification and new combinations, new names, new synonyms in Frullania (Marchantiophyta). Phytotaxa 220: 127-142.

https://doi.org/10.11646/phytotaxa.220.2.3

Hernick, L.V., Landing, E. \& Bartowski, K.E. (2008) Earth's oldest liverworts-Metzgeriothallus sharonae sp. nov. from the Middle Devonian (Givetian) of eastern New York, USA. Review of Palaeobotany and Palynology 148: 154-162. https://doi.org/10.1016/j.revpalbo.2007.09.002

Hong, W.S. (1990) The family Calypogeiaceae in North America west of the hundredth meridian. The Bryologist 93: 313-318. https://doi.org/10.2307/3243519

Horikawa, Y. (1939) Contributions to the bryological flora of Eastern Asia. VI. Journal of Japanese Botany 15: 359-368.

Hudson, W. (1778) Flora Anglica, ed. 2, tom. 2. J. Nourse, London, pp. 335-690.

Inoue, H. (1959) On Metacalypogeia, a new genus of Hepaticae. Journal of the Hattori Botanical Laboratory 21: 231-235.

Inoue, H. (1978) Anastrophyllum ellipticum Inoue (sp. nov., Hepaticae) from Japan. Bulletin of the National Science Museum, Tokyo. Series B, Botany 4: 13-17.

Iturralde-Vinent, M.A. \& MacPhee, R.D.E. (2019) Remarks on the age of Dominican amber. Palaeoentomology 2: 236-240. https://doi.org/10.11646/palaeoentomology.2.3.7

Jack, J.B. \& Stephani, F. (1892) Hepaticae Wallisianae. Hedwigia 31: 11-27.

Kaasalainen, U., Heinrichs, J., Renner, M.A.M., Hedenäs, L., Schäfer-Verwimp, A., Lee, G.E., Ignatov, M.S., Rikkinen, J. \& Schmidt, A.R. (2017) A Caribbean epiphyte community preserved in Miocene Dominican amber. Earth and Environmental Science Transactions of the Royal Society of Edinburgh 107: 321-331. https://doi.org/10.1017/S175569101700010X

Kachroo, P. (1968) History of the genus Cheilolejeunea. Ceylon Journal of Science. Biological Sciences 8: 1-10.

Kasiński, J.R., Kramarska, R., Słodkowska, B., Sivkov, V. \& Piwocki, M. (2020) Paleocene and Eocene deposits on the eastern margin of the Gulf of Gdańsk (Yantarny P-1 borehole, Kaliningrad region, Russia). Geological Quarterly 64: 29-53. https://doi.org/10.7306/gq.1513

Katagiri, T. (2015) First fossil record of the liverwort family Cephaloziaceae (Jungermanniales, Marchantiophyta) from Baltic amber. Nova Hedwigia 101: 347-354.

https://doi.org/10.1127/nova_hedwigia/2015/0276

Katagiri, T. (2018) Geocalyx heinrichsii sp. nov., the first representative of Geocalycaceae (Jungermanniales, Marchantiophyta) in Baltic amber. Bryophyte Diversity and Evolution 40: 113-117.

https://doi.org/10.11646/bde.40.2.9

Katagiri, T. \& Shinden, H. (2020) Discovery of a simple thalloid liverwort Metzgeriites kujiensis (Metzgeriaceae), a new species from Late Cretaceous Japanese amber. Hattoria 11: 13-21.

https://doi.org/10.18968/hattoria.11.0_13

Kettunen, E., Sadowski, E.-M., Seyfullah, L.J., Dörfelt, H., Rikkinen, J. \& Schmidt, A.R., (2019) Caspary's fungi from Baltic amber: historic specimens and new evidence. Papers in Palaeontology 5: 365-389.

https://doi.org/10.1002/spp2.1238

Kitagawa, N. (1964) A new genus of Hepaticae from North Borneo. Journal of the Hattori Botanical Laboratory 27: $178-182$.

Konstantinova, N.A. \& Vasiljev, A.N. (1994) On the hepatic flora of Sayan Mountains (South Siberia). Arctoa 3: $123-132$. https://doi.org/10.15298/arctoa.03.07

Konstantinova, N.A. \& Vilnet, A.A. (2009) New taxa and new combinations in Jungermanniales (Hepaticae). Arctoa 18: 65-67. https://doi.org/10.15298/arctoa.18.02

Konstantinova, N.A., Ignatov, M.S. \& Perkovsky, E.E. (2012) Hepatics from Rovno amber (Ukraine). Arctoa 21: $265-271$. https://doi.org/10.15298/arctoa.21.25

Kosmowska-Ceranowicz, B. (2001) The amber treasure trove. Museum of the Earth Documentary Studies 18: 1-97.

Khotimperwati, L., Kasiamdari, R.S., Santosa, S. \& Daryono, B.S. (2018) Bazzania Gray (Lepidoziaceae, Marchantiophyta) in Central 
Java, Indonesia. Biodiversitas 19: 875-887.

https://doi.org/10.13057/biodiv/d190316

Krassilov, V.A. (1970) Leafy hepatics from the Jurassic of the Bureja basin. Paleontologicheskij Zhurnal 4 (3): 131-142. [in Russian]

Krassilov, V.A. (1973) Mesozoic bryophytes from the Bureja basin, Far East of the USSR. Palaeontographica B 143: 95-105.

Krassilov, V.A. \& Schuster, R.M. (1984) Paleozoic and Mesozoic fossils. In: Schuster, R.M. (Ed.) New Manual of Bryology. The Hattori Botanical Laboratory, Nichinan, pp. 1172-1193.

Kubilius, R.A., Bölz, A., Feldberg, K., Hedenäs, L., Schäfer-Verwimp, A., Schmidt, A.R. \& Heinrichs, J. (2017) The moss Helicophyllum torquatum (Bryopsida, Helicophyllaceae) has survived since at least the Miocene. Botanical Journal of the Linnean Society 185: $56-64$.

https://doi.org/10.1093/botlinnean/box041

Laenen, B., Shaw, B., Schneider, H., Goffinet, B., Paradis, E., Désamoré, A., Heinrichs, J., Villarreal, J.C., Gradstein, S.R., McDaniel, S.F., Long, D.G., Forrest, L.L., Hollingsworth, M.L., Crandall-Stotler, B., Davis, E.C., Engel, J., von Konrat, M., Cooper, E.D., Patiño, J., Cox, C.J., Vanderpoorten, A. \& Shaw, A.J. (2014) Extant diversity of bryophytes emerged from successive post-Mesozoic diversification bursts. Nature Communications 5: 6134.

https://doi.org/10.1038/ncomms6134

Lee, G.E. (2013) A systematic revision of the genus Lejeunea Lib. (Marchantiophyta: Lejeuneaceae) in Malaysia. Cryptogamie, Bryologie 34: 381-484.

https://doi.org/10.7872/cryb.v34.iss4.2013.381

Lee, G.E., Bechteler, J., Schäfer-Verwimp, A. \& Heinrichs, J. (2015a) Microlejeunea miocenica sp. nov. (Porellales, Jungermanniopsida) in Dominican amber, the first fossil of a subcosmopolitan genus of leafy liverworts. Review of Palaeobotany and Palynology 222: $16-21$. https://doi.org/10.1016/j.revpalbo.2015.07.002

Lee, G.E., Schäfer-Verwimp, A., Schmidt, A.R. \& Heinrichs, J. (2015b) Transfer of the Miocene Lejeunea palaeomexicana Grolle to Ceratolejeunea. Cryptogamie, Bryologie 36: 335-341.

https://doi.org/10.7872/cryb/v36.iss4.2015.335

Lee, G.E., Kolberg, L., Bechteler, J., Schäfer-Verwimp, A., Renner, M.A.M., Schmidt, A.R. \& Heinrichs, J. (2017) The leafy liverwort genus Lejeunea (Porellales, Jungermanniopsida) in Miocene Dominican amber. Review of Palaeobotany and Palynology 238: 144150.

https://doi.org/10.1016/j.revpalbo.2016.11.013

Lee, G.E., Condamine, F.L., Bechteler, J., Pérez-Escobar, O.A., Scheben, A., Schäfer-Verwimp, A., Pócs, T. \& Heinrichs, J. (2020) An ancient tropical origin, dispersals via land bridges and Miocene diversification explain the subcosmopolitan disjunctions of the liverwort genus Lejeunea. Scientific Reports 10: 14123. https://doi.org/10.1038/s41598-020-71039-1

Lehmann, J.G.C. (1832) Novarum et minus cognitarum stirpium pugillus quartus. Meissner, Hamburg, 64 pp. https://doi.org/10.5962/bhl.title.45011

Lehmann, J.G.C. (1834) Novarum et minus cognitarum stirpium pugillus sextus. Meissner, Hamburg, 72 pp. https://doi.org/10.5962/bhl.title.45011

Lehmann, J.G.C. (1844) Novarum et minus cognitarum stirpium pugillus octavus. Meissner, Hamburg, 56 pp. https://doi.org/10.5962/bhl.title.45011

Li, Y., Wang, Y.-D., Schneider, H. \& Wu, P.-C. (2020) Frullania partita sp. nov. (Frullaniaceae, Porellales), a new leafy liverwort from the mid-Cretaceous of Myanmar. Cretaceous Research 108: 104341. https://doi.org/10.1016/j.cretres.2019.104341

Li, Y., Li, L.-Q., Feldberg, K., Wu, P.-C., Schneider, H., Schmidt, A.R. \& Wang, Y.-D. (2021) Re-appraisal of two fossil Frullaniaceae species (Marchantiophyta, Porellales) from the mid-Cretaceous Burmese amber. Cretaceous Research 124: 104803. https://doi.org/10.1016/j.cretres.2021.104803

Libert, M.-A. (1820) Sur un genre nouveau d'hépatiques, Lejeunia. Annales générales des sciences physiques 6: 372-374.

Lima, E., Ilkiu-Borges, A.L. \& Gradstein, S.R. (2020) A new species of Frullania subg. Frullania (Marchantiophyta) from the Brazilian Amazon. Phytotaxa 456 (1): 119-124.

https://doi.org/10.11646/phytotaxa.456.1.10

Lindberg, S.O. (1872) Contributio ad floram cryptogamam Asiae boreali-orientalis. Acta Societatis Scientiarum Fennicae 10: 221-280.

Lindenberg, J.B.W. (1829) Synopsis hepaticarum europaearum. Eduard Weberum, Bonnae, 133 pp.

Lindenberg, J.B.W. (1840) Species hepaticarum, fasc. 2-4. Henry \& Cohen, Bonn, pp. 37-120.

Linnaeus, C. (1753) Species plantarum, ed. 1. Laurentii Salvii, Holmiae [Stockholm], 1200 pp.

Loeske, L. (1905) Bryologisches vom Harze und aus anderen Gebieten. Verhandlungen des Botanischen Vereins der Provinz Brandenburg 
47: 317-344.

Loeske, L. (1908) Bryologische Beobachtungen aus den Algäuer Alpen von Loeske und Osterwald. Verhandlungen des Botanischen Vereins der Provinz Brandenburg 49: 30-65.

Loeske, L. (1909) Zur Moosflora der Zillertaler Alpen. Hedwigia 49: 1-53.

Lóriga, J., Schmidt, A.R., Moran, R.C., Feldberg, K., Schneider, H. \& Heinrichs, J. (2014) The first fossil of a bolbitidoid fern belongs to the early divergent lineages of Elaphoglossum (Dryopteridaceae). American Journal of Botany 101: 1466-1475. https://doi.org/10.3732/ajb.1400262

Magallón S., Hilu, K.W. \& Quandt, D. (2013) Land plant evolutionary timeline: Gene effects are secondary to fossil constraints in relaxed clock estimation of age and substitution rates. American Journal of Botany 100: 556-573.

https://doi.org/10.3732/ajb.1200416

Mägdefrau, K. (1957) Flechten und Moose im baltischen Bernstein. Berichte der Deutschen Botanischen Gesellschaft 70: $433-435$.

Mamontov, Y.S., Heinrichs, J., Schäfer-Verwimp, A., Ignatov, M.S. \& Perkovsky, E.E. (2013) Hepatics from Rovno amber (Ukraine), 2. Acrolejeunea ucrainica sp. nov. Arctoa 22: 93-96.

https://doi.org/10.15298/arctoa.22.13

Mamontov, Y.S., Heinrichs, J., Schäfer-Verwimp, A., Ignatov, M.S. \& Perkovsky, E.E. (2015a) Hepatics from Rovno amber (Ukraine), 4. Frullania riclefgrollei, sp. nov. Review of Palaeobotany and Palynology 223: 31-36.

https://doi.org/10.1016/j.revpalbo.2015.08.007

Mamontov, Y.S., Heinrichs, J., Váňa, J., Ignatov, M.S. \& Perkovsky, E.E. (2015b) Hepatics from Rovno amber (Ukraine), 3. Anastrophyllum rovnoi sp. nov. Arctoa 24: 43-46.

https://doi.org/10.15298/arctoa.24.08

Mamontov, Y.S., Heinrichs, J., Váňa, J., Ignatov, M.S. \& Perkovsky, E.E. (2015c) Hepatics from Rovno amber (Ukraine), 5. Cephaloziella nadezhdae sp. nov. Arctoa 24: 289-293.

https://doi.org/10.15298/arctoa.24.25

Mamontov, Y.S., Hentschel, J., Konstantinova, N.A., Perkovsky, E.E. \& Ignatov, M.S. (2017) Hepatics from Rovno amber (Ukraine), 6. Frullania rovnoi, sp. nov. Journal of Bryology 39: 336-341.

https://doi.org/10.1080/03736687.2017.1343220

Mamontov, Y.S., Ignatov, M.S. \& Perkovsky, E.E. (2018a) Hepatics from Rovno amber (Ukraine), 7. Frullania zerovii, sp. nov. Nova Hedwigia 106: 103-113.

https://doi.org/10.1127/nova_hedwigia/2017/0446

Mamontov, Y.S., Vilnet, A.A. \& Potemkin, A.D. (2018b) Scapania marsupelloides sp. nov. (Scapaniaceae, Marchantiophyta), a remarkable new species near the base of Scapania phylogeny. Phytotaxa 385 (2): 55-66. https://doi.org/10.11646/phytotaxa.385.2.1

Mamontov, Y.S., Ignatov, M.S. \& Perkovsky, E.E. (2019) Liverworts from Rovno amber (Ukraine). 8. Frullania ekaterinae sp. nov. and F. schmalhausenii sp. nov. Paleontological Journal 53: 1095-1103.

https://doi.org/10.1134/S0031030119100113

Mamontov, Y.S., Atwood, J.J., Perkovsky, E.E. \& Ignatov, M.S. (2020a) Hepatics from Rovno amber (Ukraine): Frullania pycnoclada and a new species, F. vanae. The Bryologist 123: 421-430.

https://doi.org/10.1639/0007-2745-123.3.421

Mamontov, Y.S., Vilnet, A.A., Atwood, J.J. \& Konstantinova, N.A. (2020b) Molecular phylogenetic study of Frullania subsect. Inflatae (Frullaniaceae, Marchantiophyta) in the Holarctic with description of a new subgenus and three new species. Nova Hedwigia Beiheft 150: 201-242. https://doi.org/10.1127/nova-supp1/2020/201

Marshall, C.R. (2019) Using the fossil record to evaluate timetree timescales. Frontiers in Genetics 10: 1049. https://doi.org/10.3389/fgene.2019.01049

Massalongo, C. \& Carestia, A. (1880) Epatiche delle Alpi Pennine. Nuovo Giornale Botanico Italiano 12: 306-366. Tav. VIII-XI.

Meagher, D.A. (2019) A synopsis of the genus Bazzania (Marchantiophyta: Lepidoziaceae) in Australia. Australian Systematic Botany 32: $310-362$.

https://doi.org/10.1071/SB18025

Mitten, W. (1860a) Hepaticae Indiae Orientalis. Journal of the Proceedings of the Linnean Society. Botany 5: 89-128. https://doi.org/10.1111/j.1095-8312.1860.tb01045.x

Mitten, W. (1860b) On some new species of musci and hepaticae in the herbarium of sir W. J. Hooker, collected in tropical Africa, chiefly by the late Dr. Vogel and Mr. Barger. Transactions of the Linnean Society of London 23: 51-58.

https://doi.org/10.1111/j.1096-3642.1860.tb00117.x

Mitten, W. (1864a) On some species of Musci and Hepaticae, additional to the floras of Japan and the coast of China. Botanical Journal 
of the Linnean Society 8: 148-158.

https://doi.org/10.1111/j.1095-8312.1864.tb01081.x

Mitten, W. (1864b) The "Bryologia" of the survey of the $48^{\text {th }}$ parallel of latitude. Botanical Journal of the Linnean Society 8: 12-55. https://doi.org/10.1111/j.1095-8312.1864.tb01071.x

Mitten, W. (1871) Jungermanniae and Marchantiae. In: Seemann, B. (Ed.) Flora vitiensis, part 10. Reeve, London, pp. $404-419$. https://doi.org/10.5962/bhl.title.455

Montagne, J.F.C. (1840) Seconde centurie de plantes cellulaires exotiques nouvelles. Décades VI, VII et VIII. Annales des Sciences Naturelles; Botanique (sér. 2) 14: 321-350.

Montagne, J.F.C. (1842) Botanique. Plantes cellulaires. In: de la Sagra, R.D.J. (Ed.) Histoire Physique, Politique et Naturelle de l'Ile de Cuba. Arthus Bertrand, Paris, pp. 427-492.

https://doi.org/10.5962/bhl.title.51128

Morris, J.L., Puttick, M.N., Clark, J.W., Edwards, D., Kenrick, P., Pressel, S., Wellman, C.H., Yang, Z., Schneider, H. \& Donoghue, P.C.J. (2017) The timescale of early land plant evolution. Proceedings of the National Academy of Sciences of the United States of America 115: E2274-E2283. https://doi.org/10.1073/pnas.1719588115

Müller, K. (1904) Über die in Baden in den Jahren 1902 und 1903 gesammelten Lebermoose. Beihefte zum Botanischen Centralblatt 17: $211-233$.

Müller, K. (1905) Monographie der Lebermoosgattung Scapania Dum. Nova Acta Academiae Caesareae Leopoldino-Carolinae Germanicae Naturae Curiosorum 83: 1-312.

Müller, K. (1912) Die Lebermoose (Dr. L. Rabenhorst's Kryptogamen-Flora von Deutschland, Oesterreich und der Schweiz, 2 Aufl., 6 Band), 2 Abth., 16 Lieferung. Eduard Kummer, Leipzig, pp. 81-144. https://doi.org/10.5962/bhl.title.1356

Nees, C.G. (1830) Enumeratio plantarum cryptogamicarum Javae et insularum adiacentium. Grass, Barth \& Co, Breslau, 86 pp.

Nees, C.G. (1833a) Hepaticae Hedw. In: Martius, C.F.P. (ed.) Flora brasiliensis. Sumptibus J. G. Cottae, Stuttgart, pp. $294-390$. https://doi.org/10.5962/bhl.title.454

Nees, C.G. (1833b) Naturgeschichte der Europäischen Lebermoose, vol. 1. August Rücker, Berlin, 347 pp.

Oostendorp, C. (1987) The bryophytes of the Paleozoic and Mesozoic. Bryophytorum Bibliotheca 34: 5-112. Plates I-XLIX.

O'Reilly, J.E. \& Donoghue, P.C.J. (2020) The effect of fossil sampling on the estimation of divergence times with the fossilized birthdeath process. Systematic Biology 69: 124-138.

https://doi.org/10.1093/sysbio/syz037

Parham, J.F., Donoghue, P.C.J., Bell, C.J., Calwey, T.D., Head, J.J., Holroyd, P.A., Inoue, J.G., Irmis, R.B., Joyce, W.G., Ksepka, D.T., Patané, J.S.L., Smith, N.D., Tarver, J.E., van Tuinen, M., Yang, Z., Angielczyk, K.D., Greenwood, J.M., Hipsley, C.A., Jacobs, L., Makovicky, P.J., Müller, J., Smith, K.T., Theodor, J.M., Warnock, R.C.M. \& Benton, M.J. (2012) Best practices for justifying fossil calibrations. Systematic Biology 61: 346-359.

https://doi.org/10.1093/sysbio/syr107

Patiño, J., Wang, J., Renner, M.A.M., Gradstein, S.R., Laenen, B., Devos, N., Shaw, A.J. \& Vanderpoorten, A. (2017) Range size heritability and diversification patterns in the liverwort genus Radula. Molecular Phylogenetics and Evolution 106: 73-85.

https://doi.org/10.1016/j.ympev.2016.09.020

Paton, J.A. (1999) The liverwort flora of the British Isles. Harley Books, Colchester, $626 \mathrm{pp}$.

Patzak, S.D.F., Renner, M.A.M., Schäfer-Verwimp, A., Feldberg, K., Heslewood, M.M., Peralta, D.F., de Souza, A.M., Schneider, H. \& Heinrichs, J. (2016) A phylogeny of Lophocoleaceae-Plagiochilaceae-Brevianthaceae and a revised classification of Plagiochilaceae. Organisms Diversity and Evolution 16: 481-495.

https://doi.org/10.1007/s13127-015-0258-y

Pearson, W.H. (1894) Frullania microphylla. Journal of Botany, British and Foreign 32: 328-330.

Penney, D. (2010) Dominican amber. In: Penney, D. (Ed.) Biodiversity of fossils in amber from the major world deposits. Siri Scientific Press, Manchester, pp. 22-41.

Perkovsky, E.E., Zosimovich, V.Y. \& Vlaskin, A.P. (2010) Rovno amber. In: Penney, D. (Ed.) Biodiversity of fossils in amber from the major world deposits. Siri Scientific Press, Manchester, pp. 116-136.

Persson, H. (1954) On Neohodgsonia H. Perss. the new hepatic genus from New Zealand and Tristan da Cunha. Botaniska Notiser 107: 39-44.

Pett, W. \& Heath, T.A. (2020) Inferring the timescale of phylogenetic trees from fossil data. In: Scornavacca, C., Delsuc, F. \& Galtier, N. (eds.) Phylogenetics in the genomic era. No commercial publisher, authors open access book, pp. 5.1:1-5.1:18.

Pócs, T., Müller, F. \& Shevock, J.R. (2015) Additions to the liverwort and hornwort flora of São Tomé and Príncipe II, with Neurolejeunea, a genus new to Africa. Herzogia 28: 50-69. 
https://doi.org/10.13158/heia.28.1.2015.50

Potemkin, A.D. \& Müller, F. (2020) The genus Scapania (Scapaniaceae, Marchantiophyta) in Myanmar. Journal of Bryology 42: 386389. https://doi.org/10.1080/03736687.2020.1793079

Potemkin, A.D., Piippo, S. \& Koponen, T.J. (2004) Bryophyte flora of Hunan Province, China. 4. Diplophyllaceae and Scapaniaceae (Hepaticae). Annales Botanici Fennici 41: 415-427.

Poulsen, C. (1974) Further contributions to the knowledge of the Palaeozoic of Slagelse no. 1, Western Sealand. II. Permian roots and fossils. Danmarks Geologiske Undersøgelse II 101: 28-32.

Rabenhorst, G.L. (1862) Hepaticae Europaeae. Die Lebermoose Europa's unter Mitwirkung mehrerer namhafter Botaniker, Decades 2122. Dresden, tab. 201-220.

Raddi, G. (1818) Jungermanniografia etrusca. Modena, 45 pp.

Ramaiya, M., Johnson, M.G., Shaw, B., Heinrichs, J., Hentschel, J., von Konrat, M., Davison, P.G. \& Shaw, A.J. (2010) Morphologically cryptic biological species within the liverwort Frullania asagrayana. American Journal of Botany 97: 1707-1718. https://doi.org/10.3732/ajb.1000171

Reiner-Drehwald, M.E. \& Goda, A. (2000) Revision of the genus Crossotolejeunea (Lejeuneaceae, Hepaticae). Journal of the Hattori Botanical Laboratory 89: 1-54.

Reiner-Drehwald, M.E., Schmidt, A.R. \& Heinrichs, J. (2012) The genus Lejeunea in Miocene amber from the Dominican Republic. Cryptogamie, Bryologie 33: 33-38. https://doi.org/10.7872/cryb.v33.iss 1.2012.033

Reinwardt, C.G.C., Blume, C.L. \& Nees, C.G. (1824) Hepaticae Iavanicae, editae coniunctis studiis et opera. Nova Acta Physico-Medica Academiae Caesareae Leopoldino-Carolinae Naturae Curiosorum Exhibentia 12: 181-238.

Renner, M.A.M. (2014) Radula subg. Radula in Australasia and the Pacific (Jungermanniopsida). Telopea 17: 107-167. https://doi.org/10.7751/telopea20147553

Renner, M.A.M. (2015) Lobule shape evolution in Radula (Jungermanniopsida): one rate fits all? Botanical Journal of the Linnean Society 178: 222-242.

https://doi.org/10.1111/boj.12279

Renner, M.A.M. (2018) A revision of Australian Plagiochila (Lophocoleinae: Jungermanniopsida). Telopea 21: 187-380. https://doi.org/10.7751/telopea12959

Renner, M.A.M. (2020) Opportunities and challenges presented by cryptic bryophyte species. Telopea 23: 41-60. https://doi.org/10.7751/telopea14083

Renner, M.A.M., Devos, N., Brown, E.A. \& von Konrat, M.J. (2013a) Three modes of heterochrony explain lobule diversity in Radula subgenus Cladoradula (Porellales: Jungermanniopsida), a small lineage of early land plants today. Botanical Journal of the Linnean Society 173: 153-175.

https://doi.org/10.1111/boj.12087

Renner, M.A.M., Devos, N., Patiño, J., Brown, E.A., Orme, A., Elgey, M., Wilson, T.C., Gray, L.J. \& von Konrat, M.J. (2013b) Integrative taxonomy resolves the cryptic and pseudo-cryptic Radula buccinifera complex (Porellales, Jungermanniopsida), including two reinstated and five new species. PhytoKeys 27: 1-113.

https://doi.org/10.3897/phytokeys.27.5523

Renner, M.A.M., Brown, E.A. \& Wardle, G.M. (2013c) Averaging v. outlier removal. Decrypting variance among cryptic Lejeunea species (Lejeuneaceae: Jungermanniopsida) using geometric morphometrics. Australian Systematic Botany 26: 13-30. https://doi.org/10.1071/SB12016

Renner, M.A.M, Hesslewood, M.M., Patzak, S.D.F., Schäfer-Verwimp, A. \& Heinrichs, J. (2017a) By how much do we underestimate species diversity of liverworts using morphological evidence? An example from Australasian Plagiochila (Plagiochilaceae: Jungermanniopsida). Molecular Phylogenetics and Evolution 107: 576-593.

https://doi.org/10.1016/j.ympev.2016.12.018

Renner, M.A.M., Patzak, S.D.F., Heslewood, M.M., Schäfer-Verwimp, A. \& Heinrichs, J. (2017b) Third time lucky? Another substantially revised sectional classification for Australasian Plagiochila (Plagiochilaceae: Jungermanniopsida). Australian Systematic Botany 30 : 70-104. https://doi.org/10.1071/SB16038

Renzaglia, K.S., Crandall-Stotler, B., Pressel, S., Duckett, J.G., Schuette, S. \& Strother, P.K. (2015) Permanent spore dyads are not 'a thing of the past': on their occurrence in the liverwort Haplomitrium (Haplomitriopsida). Botanical Journal of the Linnean Society 179: 658-669.

https://doi.org/10.1111/boj.12343

Rikkinen, J. \& Poinar, G.O. Jr. (2008) A new species of Phyllopsora (Lecanorales, lichen-forming Ascomycota) from Dominican amber, 
with remarks on the fossil history of lichens. Journal of Experimental Botany 59: 1007-1011.

https://doi.org/10.1093/jxb/ern004

Ross, A., Mellish, C., York, P. \& Crighton, B. (2010) Burmese amber. In: Penney, D. (Ed.) Biodiversity of fossils in amber from the major world deposits. Siri Scientific Press, Manchester, pp. 208-235.

Rust, J., Singh, H., Rana, R.S., McCann, T., Singh, L., Anderson, K., Sarkar, N., Nascimbene, P.C., Stebner, F., Thomas, J.C., Solórzano Kraemer, M., Williams, C.J., Engel, M.S., Sahni, A. \& Grimaldi, D. (2010) Biogeographic and evolutionary implications of a diverse paleobiota in amber from the early Eocene of India. Proceedings of the National Academy of Sciences of the United States of America 107: $18360-18365$.

https://doi.org/10.1073/pnas.1007407107

Sadowski, E.-M., Schmidt, A.R., Seyfullah, L.J. \& Kunzmann, L. (2017) Conifers of the 'Baltic amber forest' and their palaeoecological significance. Stapfia 106: 1-73.

Scheben, A., Bechteler, J., Lee, G.E., Pócs, T., Schäfer-Verwimp, A. \& Heinrichs, J. (2016) Multiple transoceanic dispersals and geographical structure in the pantropical leafy liverwort Ceratolejeunea (Lejeuneaceae, Porellales). Journal of Biogeography 43 : $1739-1749$.

https://doi.org/10.1111/jbi.12779

Schiffner, V. (1893) Hepaticae. In: Engler, A. \& Prantl, K. (Eds.) Die Natürlichen Pflanzenfamilien, Teil I, Abt. 3. Engelmann, Leipzig, pp. $1-141$.

https://doi.org/10.5962/bhl.title.4635

Schiffner, V. (1898) Conspectus hepaticarum archipelagi indici. Staatsdruckerei, Batavia, 382 pp.

Schiffner, V. (1900) Die Hepaticae der Flora von Buitenzorg. I. Band. E. J. Brill, Leiden, 220 pp.

Schljakov, R.N. (1976) Combinationes et taxa anthocerotarum et hepaticarum nova. Novosti Sistematiki Nizših Rastenij 13: 225-229.

Schljakov, R.N. (1979) Additamenta nova ad floram hepaticarum regionum septentrionalium URSS. Novosti Sistematiki Nizših Rastenij 16: 201-208.

Schneider, H., Schmidt, A.R., Nascimbene, P.C. \& Heinrichs, J. (2015) A new Dominican amber fossil of the derived fern genus Pleopeltis confirms generic stasis in the epiphytic fern diversity of the West Indies. Organisms Diversity and Evolution 15: $277-283$. https://doi.org/10.1007/s13127-015-0200-3

Schneider, H., Schmidt, A.R. \& Heinrichs, J. (2016) Burmese amber fossils bridge the gap in the Cretaceous record of polypod ferns. Perspectives in Plant Ecology, Evolution and Systematics 18: 70-78.

https://doi.org/10.1016/j.ppees.2016.01.003

Schrader, H.A. (1797) Systematische Sammlung cryptogamischer Gewächse, Zweyte Lieferung. J.C. Dietrich, Göttingen, 16 pp.

Schuster, R.M. (1956) North American Lejeuneaceae. V. Schizostipae: Ceratolejeunea. Journal of the Elisha Mitchell Scientific Society 72: 292-316.

Schuster, R.M. (1963) An annotated synopsis of the genera and subgenera of Lejeuneaceae. I. Beihefte zur Nova Hedwigia 9: 1-203.

Schuster, R.M. (1968) Studies on the hepaticae, XXIX-XLIV. A miscellany of new taxa and new range extensions. Nova Hedwigia 15: $437-529$.

Schuster, R.M. (1969) The hepaticae and anthocerotae of North America. II. Columbia University Press, New York, 1062 pp.

Schuster, R.M. (1970) Studies on antipodal hepaticae, III. Jubulopsis Schuster, Neohattoria Kamimura and Amphijubula Schuster. Journal of the Hattori Botanical Laboratory 33: 266-304.

Schuster, R.M. (1971) The ecology and distribution of hepaticae in a mahogany hammock in tropical Florida. Castanea 36: 90-111.

Schuster, R.M. (1978) Studies on Venezuelan hepaticae. I. Phytologia 39: 239-251.

https://doi.org/10.5962/bhl.part.7614

Schuster, R.M. (1980) The hepaticae and anthocerotae of North America. IV. Columbia University Press, New York, 1334 pp.

Schuster, R.M. (1981) Paleoecology, origin, distribution through time, and evolution of hepaticae and anthocerotae. In: Niklas, K.J. (ed.) Paleobotany, paleoecology, and evolution, vol. 2. Praeger, New York, pp. 129-191.

Schuster, R.M. (1985) Studies in Porellineae: New taxa of Jubulaceae. Phytologia 57: 369-373.

Schuster, R.M. (1992) The hepaticae and anthocerotae of North America. V. Columbia University Press, New York, 854 pp.

Schuster, R.M. (2000) Austral hepaticae. Part I. Nova Hedwigia Beiheft 118: 1-524.

Schuster, R.M. (2002) Austral hepaticae. Part II. Nova Hedwigia Beiheft 119: 1-606.

Schuster, R.M. \& Janssens, J.A. (1989) On Diettertia, an isolated Mesozoic member of the Jungermanniales. Review of Palaeobotany and Palynology 57: 277-287. https://doi.org/10.1016/0034-6667(89)90025-0

Scott, E.B. (1980) Jungermannites noterocladioides n. sp. (Hepaticae) from the Potomac Group (Lower Cretaceous) of Maryland, USA. Journal of Paleontology 54: 1119-1121.

Serrano-Sánchez, M. de L., Hegna, T.A., Schaaf, P., Pérez, L., Centeno-García, E. \& Vega, F.J. (2015) The aquatic and semiaquatic biota in 
Miocene amber from the Campo LA Granja mine (Chiapas, Mexico): Paleoenvironmental implications. Journal of South American Earth Sciences 62: 243-256.

https://doi.org/10.1016/j.jsames.2015.06.007

Shaw, A.J. (2001) Biogeographic patterns and cryptic speciation in bryophytes. Journal of Biogeography 28: $253-261$. https://doi.org/10.1046/j.1365-2699.2001.00530.x

Shaw, B., Crandall-Stotler, B., Ván̆a, J., Stotler, R.E., von Konrat, M., Engel, J.J., Davis, E.C., Long, D.G., Sova, P. \& Shaw, A.J. (2015) Phylogenetic relationships and morphological evolution in a major clade of leafy liverworts (phylum Marchantiophyta, order Jungermanniales): suborder Jungermanniineae. Systematic Botany 40: 27-45.

https://doi.org/10.1600/036364415X686314

Shi, G., Grimaldi, D.A., Harlow, G.E., Wang, J., Wang, J., Yang, M., Lei, W., Li, Q. \& Li, X. (2012) Age constraint on Burmese amber based on U-Pb dating of zircons. Cretaceous Research 37: 155-163.

https://doi.org/10.1016/j.cretres.2012.03.014

Shi, X.-Q., Gradstein, S.R. \& Zhu R.-L. (2015) Phylogeny and taxonomy of Archilejeunea (Marchantiophyta: Lejeuneaceae) based on molecular markers and morphology. Taxon 64: 881-892.

https://doi.org/10.12705/645.1

Silva, S.E., Silva, D.N., Almeida, T., Garcia, C.A., Paulo, O.S. \& Sim-Sim, M. (2017) Age estimates of Frullania (Frullaniaceae, Porellales) main lineages: another example of rapid and recent diversification in liverwort evolution. Systematics and Biodiversity 15: $156-165$. https://doi.org/10.1080/14772000.2016.1217096

Söderström, L. \& Séneca, A. (2006) World distribution patterns in the Lophoziaceae/Scapaniaceae complex (Hepaticae, Bryophyta). Journal of the Hattori Botanical Laboratory 100: 431-441.

Söderström, L., Weibull, H. \& Damsholt, K. (2000) A new species of Lophozia (subgen. Protolophozia) from Fennoscandia. Lindbergia 25: $3-7$.

Söderström, L., De Roo, R. \& Hedderson, T. (2010) Taxonomic novelties resulting from recent reclassification of the Lophoziaceae/ Scapaniaceae clade. Phytotaxa 3: 47-53.

https://doi.org/10.11646/phytotaxa.3.1.7

Söderström, L., Hagborg, A., von Konrat, M., Bartholomew-Began, S., Bell, D., Briscoe, L., Brown, E., Cargill, D.C., Costa, D.P., Crandall-Stotler, B.J., Cooper, E.D., Dauphin, G., Engel, J.J., Feldberg, K., Glenny, D., Gradstein, S.R., He, X., Heinrichs, J., Hentschel, J., Ilkiu-Borges, A.L., Katagiri, T., Konstantinova, N.A., Larraín, J., Long, D.G., Nebel, M., Pócs, T., Puche, F., ReinerDrehwald, E., Renner, M.A.M., Sass-Gyarmati, A., Schäfer-Verwimp, A., Segarra Moragues, J.G., Stotler, R.E., Sukkharak, P., Thiers, B.M., Uribe, J., Ván̆a, J., Villarreal, J.C., Wigginton, M., Zhang, L. \& Zhu, R.-L. (2016) World checklist of hornworts and liverworts. PhytoKeys 59: 1-828.

https://doi.org/10.3897/phytokeys.59.6261

Solórzano Kraemer, M.M. (2010) Mexican amber. In: Penney, D. (Ed.) Biodiversity of fossils in amber from the major world deposits. Siri Scientific Press, Manchester, pp. 42-56.

Spruce, R. (1884) Hepaticae amazonicae et andinae. I. Transactions and Proceedings of the Botanical Society of Edinburgh 15: 1-308. https://doi.org/10.5962/bhl.title.115637

Spruce, R. (1885) Hepaticae amazonicae et andinae. II. Transactions and Proceedings of the Botanical Society of Edinburgh 15: 309588.

https://doi.org/10.5962/bhl.title.115637

Steere, W.C. (1946) Cenozoic and Mesozoic bryophytes of North America. The American Midland Naturalist 36: $298-324$. https://doi.org/10.2307/2421507

Stephani, F. (1886a) Hepaticae africanae. Botanische Jahrbücher für Systematik, Pflanzengeschichte und Pflanzengeographie 8: 79-95.

Stephani, F. (1886b) Hepaticae von der Halbinsel Alaska, gesammelt 1881/82 von den Doctoren Arthur und Aurel Krause. Botanische Jahrbücher für Systematik, Pflanzengeschichte und Pflanzengeographie 8: 96-99.

Stephani, F. (1888a) Hepaticae africanae. Hedwigia 27: 59-63.

Stephani, F. (1888b) Hepaticae africanae. Hedwigia 27: 106-113.

Stephani, F. (1890) Hepaticae africanae novae in insulis Bourbon, Maurice et Madagascar lectae. Botanical Gazette 15: $281-292$. https://doi.org/10.1086/326585

Stephani, F. (1891) Hepaticae africanae. Hedwigia 30: 201-217.

Stephani, F. (1892) The North American Lejeuneae. Botanical Gazette 17: 170-173. https://doi.org/10.1086/326806

Stephani, F. (1893) Hepaticarum species novae. Pars II. Hedwigia 32: 137-147.

Stephani, F. (1895) Hepaticae. In: Engler, A. (Ed.) Die Pflanzenwelt Ost-Afrikas und der Nachbargebiete. Theil C. Verzeichniss der bis 
jetzt aus Ost-Afrika bekannt gewordenen Pflanzen. Dietrich Reimer Verlag, Berlin, pp. 62-66.

https://doi.org/10.5962/bhl.title.587

Stephani, F. (1896a) Hepaticae. In: Reinecke, F. (Ed.) Die Flora der Samoa Inseln. Botanische Jahrbücher für Systematik, Pflanzengeschichte und Pflanzengeographie 23: 237-368.

Stephani, F. (1896b) Hepaticarum species novae IX. Hedwigia 35: 73-140.

Stephani, F. (1902) Species hepaticarum 2. Bulletin de l'Herbier Boissier (sér. 2) 2: 35-48. https://doi.org/10.5962/bhl.title.95494

Stephani, F. (1904) Hepaticarum species novae X. Hedwigia 44: 14-15.

Stephani, F. (1908) Species hepaticarum 3. Bulletin de l'Herbier Boissier (sér. 2) 8: 483-514. https://doi.org/10.5962/bhl.title.95494

Stephani, F. (1910) Species hepaticarum 4. George \& Cie, Genève \& Bale, pp. 97-448. https://doi.org/10.5962/bhl.title.95494

Stephani, F. (1915) Species hepaticarum 5. George \& Cie, Genève \& Bale, pp. 705-832. https://doi.org/10.5962/bhl.title.95494

Stephani, F. (1922) Species hepaticarum 6. George \& Cie, Genève \& Bale, pp. 241-368. https://doi.org/10.5962/bhl.title.45014

Stephani, F. (1924) Species hepaticarum 6. George \& Cie, Genève \& Bale, pp. 433-622. https://doi.org/10.5962/bhl.title.45014

Stotler, R.E. \& Crandall-Stotler, B. (2017) A synopsis of the liverwort flora of North America North of Mexico. Annals of the Missouri Botanical Garden 102: 574-709. https://doi.org/10.3417/2016027

Sukkharak, P. \& Gradstein, S.R. (2014) A taxonomic revision of the genus Mastigolejeunea (Marchantiophyta: Lejeuneaceae). Nova Hedwigia 99: 279-345. https://doi.org/10.1127/0029-5035/2014/0206

Sukkharak, P. \& Gradstein, S.R. (2017) Phylogenetic study of Mastigolejeunea (Marchantiophyta: Lejeuneaceae) and an amended circumscription of the genus Thysananthus. Phytotaxa 326 (2): 91-107.

https://doi.org/10.11646/phytotaxa.326.2.1

Sun, L.-W., Gradstein, S.R., Dai, Z., Ma, W.-Z., Shi, R.-P., Wei, Q.-Q., Gao, X.-D. \& Wang, J. (2018) Notes on the distribution of Acrolejeunea sandvicensis (Gottsche) Steph., a liverwort species disjunctive between East Asia and Hawaii. Phytotaxa 367 (2): $158-164$. https://doi.org/10.11646/phytotaxa.367.2.5

Sun, Y., He, X. \& Glenny, D. (2014) Transantarctic disjunctions in Schistochilaceae (Marchantiophyta) explained by early extinction events, post-Gondwanan radiations and palaeoclimatic changes. Molecular Phylogenetics and Evolution 76: 189-201. https://doi.org/10.1016/j.ympev.2014.03.018

Sundue, M. \& Poinar, G. Jr. (2016) An extinct grammitid fern genus from Dominican amber, with revision of Grammitis succinea. Review of Palaeobotany and Palynology 233: 193-198. https://doi.org/10.1016/j.revpalbo.2016.04.004

Swartz, O. (1788) Nova genera et species plantarum prodromus. Bibliopolio. I.G. Mülleriano, Lipsiae [Leipzig], 152 pp.

Taylor, T. (1846) New hepaticae. London Journal of Botany 5: 365-417.

Taylor, W.A., Strother, P.K., Vecoli, M. \& Al-Hajri, S. (2017) Wall ultrastructure of the oldest embryophytic spores: Implications for early land plant evolution. Revue de Micropaléontologie 60: 281-288. https://doi.org/10.1016/j.revmic.2016.12.002

Tomescu, A.M.F., Bomfleur, B., Bippus, A.C. \& Savoretti, A. (2018) Why are bryophytes so rare in the fossil record? A spotlight on taphonomy and fossil preservation. In: Krings, M., Cúneo, N.R., Harper, C.J. \& Rothwell, G.W. (Eds.) Transformative Paleobotany. Papers to commemorate the life and legacy of Thomas N. Taylor. Elsevier/Academic Press, New York, pp. 375-416.

https://doi.org/10.1016/B978-0-12-813012-4.00016-4

Townrow, J.A. (1959) Two Triassic bryophytes from South Africa. Journal of South African Botany 25: 1-22.

Trevisan de Saint-Léon, V.B.A. (1877) Schema di una nuova classificazione delle Epatiche. Memorie del Reale Istituto Lombardo di Scienze e Lettere, Serie 3, Classe di Scienze Matematiche e Naturali 4: 383-451.

Vainio, E. (1878) Itä-Hämeen kasvistosta [Florula tavastiae orientalis]. Meddelanden af Societas pro Fauna et Flora Fennica 3: 1-121.

Váňa, J. \& Long, D.G. (2009) Jungermanniaceae of the Sino-Himalayan region. Nova Hedwigia 89: 485-517. https://doi.org/10.1127/0029-5035/2009/0089-0485

Váňa, J., Söderström, L., Hagborg, A. \& von Konrat, M. (2013a) Notes on Early Land Plants Today. 24. What is Protolophozia? (Cephaloziellaceae, Marchantiophyta). Phytotaxa 76 (3): 50-54. 
https://doi.org/10.11646/phytotaxa.76.3.12

Váňa, J., Söderström, L., Hagborg, A. \& von Konrat, M. (2013b) Notes on Early Land Plants Today. 41. New combinations and synonyms in Cephaloziaceae (Marchantiophyta). Phytotaxa 112 (1): 7-15.

https://doi.org/10.11646/phytotaxa.112.1.2

Váňa, J., Schäfer-Verwimp, A., Bechteler, J., Schmidt, A.R. \& Heinrichs, J. (2015a) Notoscyphus grollei sp. nov. in Bitterfeld amber rather than the extant Notoscyphus lutescens (Lehm. \& Lindenb.) Mitt. Phytotaxa 222 (2): 151-154.

https://doi.org/10.11646/phytotaxa.222.2.8

Váňa, J., Schäfer-Verwimp, A., Bechteler, J., Schmidt, A.R. \& Heinrichs, J. (2015b) Transfer of the Eocene Jungermannia berendtii Grolle to Solenostoma. Cryptogamie, Bryologie 36: 285-288.

https://doi.org/10.7872/cryb/v36.iss3.2015.285

Verdoorn, F. (1930) Die Frullaniaceae der Indomalesischen Inseln (De Frullaniaceis VII). Annales Bryologici, suppl. 1: 1-187.

Verdoorn, F. (1934) De Frullaniaceis XV. Die Lejeuneaceae Holostipae der Indomalaya unter Berücksichtung sämtlicher aus Asien, Australien, Neuseeland und Ozeanien angeführten Arten. Annales Bryologici, suppl. 4: 40-192.

https://doi.org/10.1007/978-94-015-5442-8_2

Villarreal, J.C. \& Renner, S.S. (2014) A review of molecular-clock calibrations and substitution rates in liverworts, mosses, and hornworts, and a timeframe for a taxonomically cleaned-up genus Nothoceros. Molecular Phylogenetics and Evolution 78: 25-35.

https://doi.org/10.1016/j.ympev.2014.04.014

Villarreal, J.C., Crandall-Stotler, B.J., Hart, M.L., Long, D.G. \& Forrest, L.L. (2016) Divergence times and the evolution of morphological complexity in an early land plant lineage (Marchantiopsida) with a slow molecular rate. New Phytologist 209: 1734-1746. https://doi.org/10.1111/nph.13716

Vilnet, A.A., Konstantinova, N.A. \& Troitsky, A.V. (2008) Phylogeny and systematics of the genus Lophozia s. str. (Dumort.) Dumort. (Hepaticae) and related taxa from nuclear ITS1-2 and chloroplast trnL-F sequences. Molecular Phylogenetics and Evolution 47: 403-418. https://doi.org/10.1016/j.ympev.2007.12.013

Vilnet, A.A., Konstantinova, N.A. \& Troitsky, A. V. (2010) Molecular insight on phylogeny and systematics of the Lophoziaceae, Scapaniaceae, Gymnomitriaceae and Jungermanniaceae. Arctoa 19: 31-50. https://doi.org/10.15298/arctoa.19.02

Vilnet, A.A., Konstantinova, N.A. \& Troitsky, A.V. (2012) Molecular phylogeny and systematics of the suborder Cephaloziineae with special attention to the family Cephaloziaceae s.l. (Jungermanniales, Marchantiophyta). Arctoa 21: 113-132. https://doi.org/10.15298/arctoa.21.11

von Konrat, M.J. \& Braggins, J.E. (2001) A taxonomic assessment of the initial branching appendages in the liverwort genus Frullania Raddi. Nova Hedwigia 72: 283-310. https://doi.org/10.1127/nova.hedwigia/72/2001/283

von Konrat, M., Braggins, J.E., Asakawa, Y. \& Toyota, M. (2006) Frullania chevalieri (Jubulaceae) in New Zealand, with a reassessment of Schusterella. The Bryologist 109: 141-156. https://doi.org/10.1639/0007-2745(2006)109[141:FCJINZ]2.0.CO;2

von Konrat, M., Hentschel, J., Heinrichs, J., Braggins, J.E. \& Pócs, T. (2010) Forty-one degrees below and sixty years in the dark: Frullania sect. Inconditum, a new section of Australasian Frullania species including F. colliculosa, sp. nov., F. hodgsoniae, nom. and stat. nov., F. aterrima, and F. hattorii (Frullaniaceae, Marchantiophyta). Nova Hedwigia 91: 471-500. https://doi.org/10.1127/0029-5035/2010/0091-0471

von Konrat, M., Hentschel, J., Heinrichs, J. \& Braggins, J.E. (2011) Deep southern hemisphere connections: a revision of Frullania sect. Amphijubula. The Bryologist 114: 52-66.

https://doi.org/10.1639/0007-2745-114.1.52

von Konrat, M., de Lange, P., Greif, M., Strozier, L., Hentschel, J. \& Heinrichs, J. (2012) Frullania knightbridgei, a new liverwort (Frullaniaceae, Marchantiophyta) species from the deep south of Aotearoa-New Zealand based on an integrated evidence-based approach. PhytoKeys 8: 13-36. https://doi.org/10.3897/phytokeys.8.2496

von Konrat, M., de Lange, P., Larraín, J., Hentschel, J., Carter, B., Shaw, J. \& Shaw, B. (2013) A small world: uncovering hidden diversity in Frullania - a new species from Aotearoa-New Zealand. Polish Botanical Journal 58: 437-447. https://doi.org/10.2478/pbj-2013-0056

Walton, J. (1925) Carboniferous Bryophyta. I. Hepaticae. Annals of Botany 39: 563-572, P1. XIII. https://doi.org/10.1093/oxfordjournals.aob.a089964

Wang, J., Gradstein, S.R., Shi, X.-Q. \& Zhu, R.-L. (2014) Phylogenetic position of Trocholejeunea and a new infrageneric classification of Acrolejeunea (Lejeuneaceae, Marchantiophyta). Bryophyte Diversity and Evolution 36: 31-44. 
https://doi.org/10.11646/bde.36.1.3

Wang, J., Gradstein, S.R., Shi, X.-Q., Zhu, R.-L. \& Do, V.T. (2015) On the occurrence of asymmetrical underleaves associated with leftright symmetry in Spruceanthus mamillilobulus (Herzog) Verd. (Lejeuneaceae), a little-known species from China and Vietnam. Journal of Bryology 37: 62-67. https://doi.org/10.1179/1743282014Y.0000000134

Wang, J., Zhu, R.-L. \& Gradstein, S.R. (2016) Taxonomic revision of Lejeuneaceae subfamily Ptychanthoideae (Marchantiophyta) in China. Bryophytorum Bibliotheca 65: 1-141.

Warnock, R.C.M., Parham, J.F., Joyce, W.G., Lyson, T.R. \& Donoghue, P.C.J. (2015) Calibration uncertainty in molecular dating analyses: there is no substitute for the prior evaluation of time priors. Proceedings of the Royal Society B 282: 20141013.

https://doi.org/10.1098/rspb.2014.1013

Warnock, R.C.M., Yang, Z. \& Donoghue, P.C.J. (2017) Testing the molecular clock using mechanistic models of fossil preservation and molecular evolution. Proceedings of the Royal Society B 284: 20170227.

https://doi.org/10.1098/rspb.2017.0227

Weber, G.H. (1778) Spicilegium florae goettingensis. Sumptibus Ettingeri, Gothae [Gotha], 288 pp.

Weber, F. (1815) Historiae muscorum hepaticarum prodromus. Aug. Hesse, Academiae bibliopolae, Kiel, 160 pp.

Weis, G. (2001) Morphologische und anatomische Untersuchungen der Sporophyten bei den Jubulaceae Klinggr. und Lejeuneaceae Casares-Gil (Hepaticae) und deren systematische Bedeutung. Bryophytorum Bibliotheca 57: 1-302.

Weitschat, W. \& Wichard, W. (2002) Atlas of plants and animals in Baltic amber. Dr. Friedrich Pfeil, München, 256 pp.

Wigginton, M.J. (2004) E.W. Jones's liverwort and hornwort flora of West Africa. Meise, National Botanic Garden, Belgium, 443 pp.

Wilson, R., Heinrichs, J., Hentschel, J., Gradstein, S.R. \& Schneider, H. (2007) Steady diversification of derived liverworts under Tertiary climatic fluctuations. Biology Letters 3: 566-569.

https://doi.org/10.1098/rsbl.2007.0287

Wilson, W. (1841) Musci americani. Warrington, $180 \mathrm{pp.}$

Winter, G. \& Schäfer-Verwimp, A. (2020) Re-evaluation of the taxonomic status of Frullania caulisequa and Frullania obcordata (Frullaniaceae, Marchantiophyta). Frahmia 19: 1-21.

Yamada, K. (1979) A revision of Asian taxa of Radula, Hepaticae. Journal of the Hattori Botanical Laboratory 45: 201-322.

Yamada, K. (1984) A Radula collection made by Dr M. L. Hicks in Queensland, Australia. Cryptogamie: Bryologie-Lichénologie 5: 191-199.

Yang, X.J. \& Wu, X.W. (2011) Sinolejeunea yimaensis gen. et sp. nov. (Hepaticae) from the Middle Jurassic Yima Formation in Henan Province of China. Science China Earth Sciences 54: 228-232.

https://doi.org/10.1007/s11430-010-4153-2

Yang, Z. (2007) PAML 4: phylogenetic analysis by maximum likelihood. Molecular Biology and Evolution 24: 1586-1591. https://doi.org/10.1093/molbev/msm088

Ye, W. \& Zhu, R.-L. (2010) Leucolejeunea, a new synonym of Cheilolejeunea (Lejeuneaceae), with special reference to new combinations and nomenclature. Journal of Bryology 32: 279-282.

https://doi.org/10.1179/037366810X12814321877507

Ye, W., Gradstein, S.R., Shaw, A.J., Shaw, B., Ho, B.-C., Schäfer-Verwimp, A., Pócs, T., Heinrichs, J. \& Zhu, R.-L. (2015) Phylogeny and classification of Lejeuneaceae subtribe Cheilolejeuneinae (Marchantiophyta) based on nuclear and plastid molecular markers. Cryptogamie, Bryologie 36: 313-333.

https://doi.org/10.7872/cryb/v36.iss4.2015.313

Yu, N.N., Gradstein, S.R. \& Narengaowa (2020) Thysananthus weiweianus N.-N. Yu \& Gradst. (Jungermanniopsida: Lejeuneaceae), a new fossil species in Dominican amber. Chenia 14: 58-62.

Yu, T., Kelly, R., Mu, L., Ross, A., Kennedy, J., Broly, P., Xia, F., Zhang, H., Wang, B. \& Dilcher, D. (2019) An ammonite trapped in Burmese amber. Proceedings of the National Academy of Sciences of the United States of America 116: 11345-11350. https://doi.org/10.1073/pnas.1821292116

Zhou, L.-P., Zhang, L. \& Xing, F.-W. (2012) The genus Bazzania in China and adjacent regions. 1. Bazzania dulongensis L.-P.Zhou \& L.Zhang sp. nov. and Bazzania hainanensis L.-P. Zhou \& L.Zhang sp. nov. Journal of Bryology 34: 22-31. https://doi.org/10.1179/1743282011Y.0000000039 